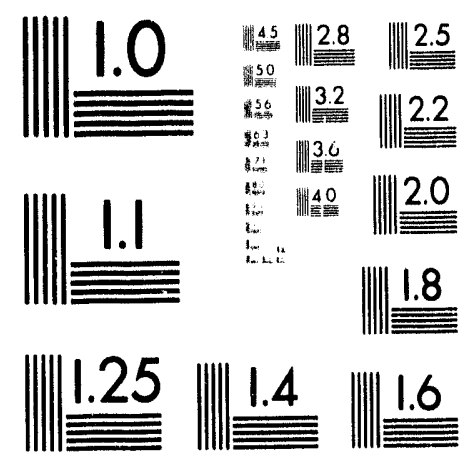



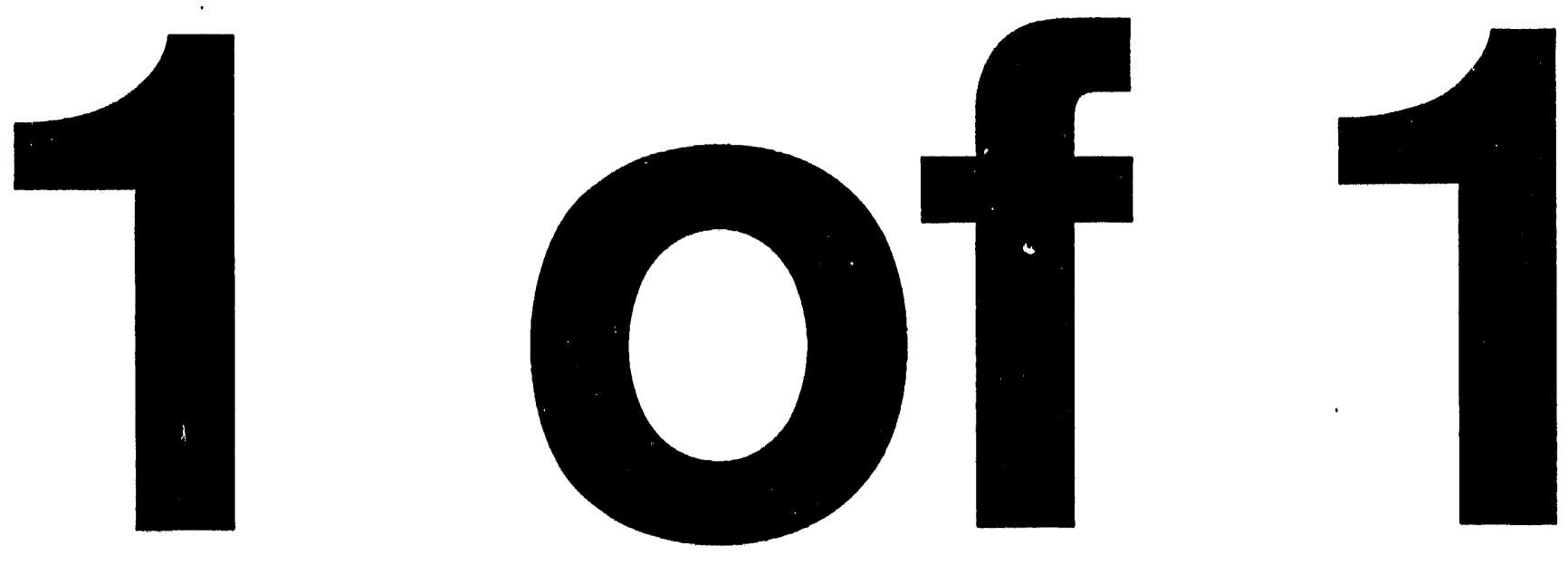
NUREG/CR-4667

ANL-93/27

Vol. 16

R5

\section{Environmentally Assisted Cracking in Light Water Reactors}

Semiannual Report

October 1992-March 1993

Manuscript Completed: August 1993

Date Published: September 1993

\section{Prepared by}

H. M. Chung, O. K. Chopra, W. E. Ruther, T. F. Kassner,

W. F. Michaud, J. Y. Park, J. E. Sanecki, W. J. Shack

Argonne National Laboratory

9700 South Cass Avenue

Argonne, IL 60439

\section{Prepared for}

Division of Engineering

Office of Nuclear Regulatory Research

U.S. Nuclear Regulatory Commission

Washington, DC 20555-0001

NRC FIN A2212 


\section{Previous Documents in Series}

Environmentally Assisted Cracking in Light Water Reactors Semiannual Report AprilSeptember 1985, NUREG/CR-4667 Vol. I, ANL-86-31 (June 1986).

Envtronmentally Assisted Cracking in Light Water Reactors Semtannual Report October 1985-March 1986, NUREG/CR-4667 Vol. II, ANL-86-37 (September 1987).

Environmentally Assisted Cracking in Light Water Reactors Semiannual Report AprilSeptember 1986. NUREG/CR-4667 Vol. III. ANL-87-37 (September 1987).

Environmentally Assisted Cracking in Light Water Reactors Semiannual Report October 1986March 1987, NUREG/CR-4667 Vol. IV, ANL-87-41 (December 1987).

Environmentally Assisted Cracking in Light Water Reactors Semiannual Report AprilSeptember 1987. NUREG/CR-4667 Vol. V, ANL-88-32 (June 1988).

Environmentally Assisted Cracking in Light Water Reactors Semiannual Report October 1987March 1988, NUREG/CR-4667 Vol. 6, ANL-89/10 (August 1989).

Environmentally Assisted Cracking in Light Water Reactors Semiannual Report AprilSeptember 1988, NUREG/CR-4667 Vol. 7, ANL 89/40 (March 1990).

Environmentally Assisted Cracking in Light Water Reactors Semiannual Report October 1988March 1989, NUREG/CR-4667 Vol. 8, ANL 90/4 (June 1990).

Environmentally Assisted Cracking in Light Water Reactors Semiannual Report April-September 1989, NUREG/CR-4667 Vol. 9. ANL-90/48 (March 1991).

Environmentally Assisted Cracking in Light Water Reactors Semiannual Report October $1989-$ March 1990, NUREG/CR-4667 Vol. 10, ANL-91/5 (March 1991).

Environmentally Assisted Cracking in Light Water Reactors Semiannual Report AprilSeptember 1990. NUREG/CR-4667 Vol. 11. ANL-91/9 (May 1991).

Environmentally Assisted Cracking in Light Water Reactors Semiannual Report October 1990-March 1991. NUREG/CR-4667 Vol. 12, ANL-91/24 (August 1991).

Environmentally Assisted Cracking in Light Water Reactors Semiannual Report April-September 1991. NUREG/CR-4667 Vol. 13. ANL-92/6 (March 1992).

Environmentally Assisted Cracking in Light Water Reactors Semiammal Report October 1991March 1992. NUREG/CR 4667 Vol. 14. ANL-92/30 (August 1992).

Environmentally Assisted Cracking in Light Water Reactors Semiannual Report April-September 1992. NUREG/CR-4667 Vol. 15. ANL 93/2 (June 1993). 


\title{
Environmentally Assisted Cracking in Light Water Reactors
}

by

H. M. Chung, O. K. Chopra, W. E. Ruther, T. F. Kassner,

W. F. Michaud, J. Y. Park, J. E. Saneckl, and W. J. Shack

\begin{abstract}
This report summarizes work performed by Argonne National Laboratory on fatigue and environmentally assisted cracking (EAC) in light water reactors (LWRs) during the six months from October 1992 to March 1993. Fatigue and EAC of piping, pressure vessels, and core components in LWRs are important concerns as extended reactor lifetimes are envisaged. Topics that have been investigated include (1) fatigue of low-alloy steel used in piping, steam generators, and reactor pressure vessels, (2) EAC of cast stainless steels (SSs). (3) radiation-induced segregation and irradiation-assisted stress corrosion cracking of Type 304 SS after accumulation of relatively high fluence, and (4) EAC of low-alloy steels. Fatigue tests were conducted on medium-sulfur-content A106-Gr B piping and A533-Gr B pressure vessel steels in simulated PWR water and in air. Additional crack growth data were obtained on fracture-mechanles specimens of cast austenitic SSs in the as-recelved and thermally aged conditions and chromium-nickcl-plated A533-Gr B steel in simulated bolling-water reactor (BWR) water at $289^{\circ} \mathrm{C}$. The data were compared wilh predictions based on crack growth correlations for ferritic steels in oxygenated water and correlations for wrought austenitic SS in oxygenated water developed at ANL and rates in air from Section XI of the ASME Code. Microchemical and microstructural changes in high- and commercial-purity Type 304 SS specimens from control-blade absorber tubes and a control-blade sheath from operating BWRs were studied by Auger electron spectroscopy and scanning electron microscopy.
\end{abstract}




\section{Contents}

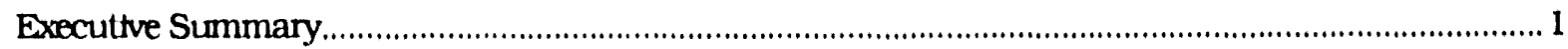

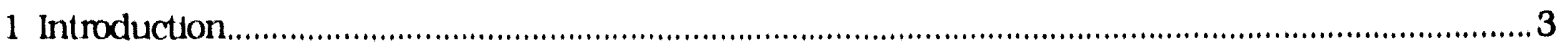

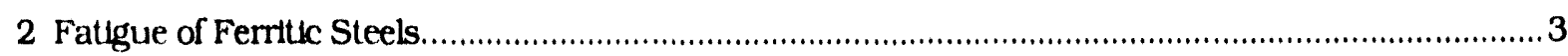

2.1 Technical Progress (O. K. Chopra, W. F. Michaud, and W. J. Shack) ......................5

3 Environmentally Assisted Cracking of Cast SSs in Simulated BWR Water..................... 19

3. 1 Technical Progress (W. E. Ruther, O. K. Chopra, and T. F. Kassner).................. 20

4 Irradiation-Assisted Stress Corrosion Cracking of Austenitic SS............................. 27

4.1 Susceptibility to Intergranular Cracking in Water and in Vacuo

(H. M. Chung, W. E. Ruther, and J. E. Sanecki) ......................................................... 29

4.2 Effect of Grain-Boundary Microchemistry (H. M. Chung, W. E. Ruther,

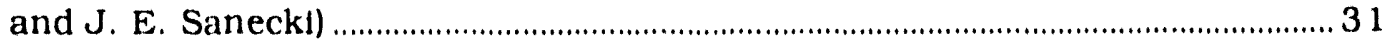

5 Environmentally Assisted Cracking of Ferritic Steels ......................................................40

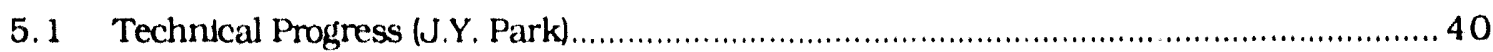

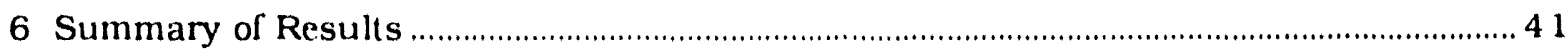

6.1 Fat igue of Ferritic Piping and Pressure Vessel Steels................................... 41

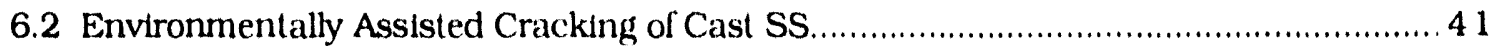

6.3 Irradiation-Assisted Stress Corrosion Cracking of Type 304 SS …....................... 46

6.4 Environmentally Assisted Cracking of Ferritic Steels..................................... 47

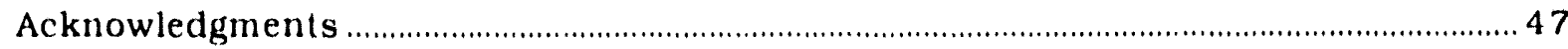

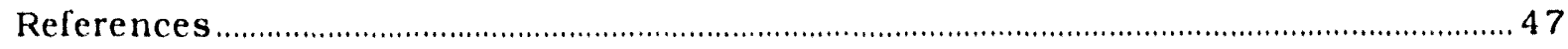




\section{Figures}

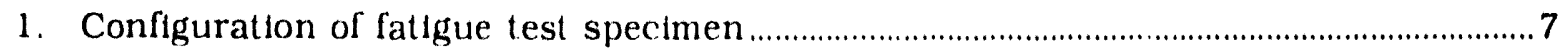

2. Microstructures of A106-Gr B carbon steel and A533-Gr B

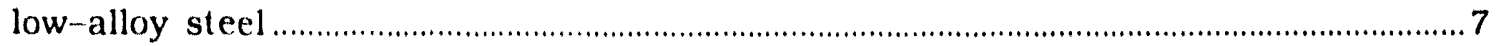

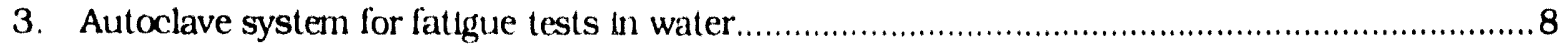

4. Schematic diagram of autoclave system for fatigue tests in water

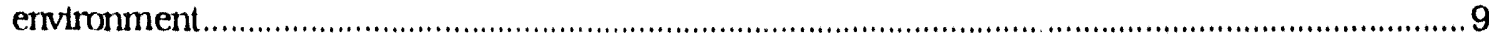

5. Total strain range vs. fatigue life data for A106-Gr B steel in air ................................. 12

6. Total strain range vs. fatlgue life data for A533-Gr B steel in alr .................................. 12

7. Total strain range vs. fatigue life data for A106-Gr B steel in PWR water at $288^{\circ} \mathrm{C}$

8. Total strain range vs. faligue life data for A533-Gr B steel in PWR water at $288^{\circ} \mathrm{C}$

9. Total straln range vs. fatigue life data for A106-Gr B steel in high-oxygen water at $288^{\circ} \mathrm{C}$.

10. Total straln range vs. fallgue llfe data for A533-Gr B steel in high-oxygen water at $288^{\circ} \mathrm{C}$

11. Effect of strain rate on fatigue life of A106-Gr B steel in highoxygen water at $288^{\circ} \mathrm{C}$

12. Effect of strain rate on cyclic strain-hardening behavior of A106-Gr B steel in air at $288^{\circ} \mathrm{C}$

13. Effect of strain rate on cyclic strain-hardening behavior of A533-Gr B steel in air at $288^{\circ} \mathrm{C}$

14. Cyclic strain-hardening behavior of A106-Gr B and A533-Gr B steels at $0.35 \%$ total strain range and $0.4 \% / \mathrm{s}$ strain rate in air

15. Cyclic stress-strain curve for A106-Gr B steel at $288^{\circ} \mathrm{C}$ in alr and water environments.

16. Cyslic stress-strain curve for $\mathrm{A} 533-\mathrm{Gr} B$ steel at $288^{\circ} \mathrm{C}$ in alr and water environments.

17. SEM micrographs of gage surface of A106-Gr B and A533-Gr B steels tested in different environments at $288^{\circ} \mathrm{C}$

18. SEM micrographs of microplts on gage surface of A106-Gr B and A533-Gr B steels tested in different environments at $288^{\circ} \mathrm{C}$ 
19. Relatuve fatigue life of A106-Gr B carbon steel at different levels of dissolved axygen and strain rates.

20. Relative fatigue 11 fe of A533-Gr B low-alloy steel at different levels of dissolved oxygen and strain rates

21. Crack growth rates of as - recelved and thermally aged CF $-8 \mathrm{M}$ and $C F-8$ grades of cast SS under high $-R$ loading in HP water at $289^{\circ} \mathrm{C}$

22. Corrosion fatigue data for as recelved $\mathrm{CF}-3,-3 \mathrm{M}$, and $-8 \mathrm{M}$ and aged $\mathrm{CF}-8 \mathrm{M}$ and -8 cast $\mathrm{SS}$ in water contalning 8 and $0.2 \mathrm{ppm}$ DO at $289^{\circ} \mathrm{C}$

23. Dependence of CGRs of as-recelved and thermally aged CF-8 and $-8 \mathrm{M}$ cast $\mathrm{SS}$ on yield stress of the materials at $289^{\circ} \mathrm{C}$ under htgh- $\mathrm{R}$ loading in water conlaining $4-8$ and $0.2-0.4 \mathrm{ppm} \mathrm{DO}$

24. Dependence of strain hardening compensated CGRs of asrecelved and thermally aged $C F-8$ and $-8 M$ cast $S S$ on yield stress of the materials at $289^{\circ} \mathrm{C}$ under high- $\mathrm{R}$ loading in water containing 4-8 and $0.2-0.4 \mathrm{ppm} \mathrm{DO}$

25. Percent IGSCC vs. lluence and yleld strength for $\mathrm{HP}$ and $\mathrm{CP}$ Type 304 SS and CP 316 SS BWR components from SSRT tests at $289^{\circ} \mathrm{C}$ in simulated $B W T$ water.

26. Percent IGSCC in water and depth of IG fracture penetralton in hydrogen-charged specimens, fractured at $25^{\circ} \mathrm{C}$ in vacuo, as a function of grain boundary segregation of Si. P. and X $(59-\mathrm{eV})$

27. Percent IGSCC from SSRT tests vs. minimum grain-boundary $\mathrm{Cr}$ content determined from AES and FEG STEM analyses of BWR components.

28. Comparison of grain boundary $\mathrm{Cr}$ depletlon profiles determined from AES analyses of HP3O4 A and HP:304 CD absorber lubes tradiated to $2 \times 10^{21}$ n. $(7)^{-2}$........

29. Intensittes of $\mathrm{Ni}, \mathrm{SI}, \mathrm{P}$, and $\mathrm{C}$ signals from ductlle, Intergranular, and faceted fracture surfaces of neutron absorber lubes fabricated from HP heats HP3O4.A and HP3O4-CD and Irradialed to $\approx 1.4 \times 10^{21}$ and $=2 \times 10^{21} \mathrm{n} \cdot\left(\mathrm{m} \mathrm{m}^{-2}\right.$, respectively

30. Intensities of Ni, Si, P, C, S, N, X $(59 \mathrm{eV})$, and B signals from ductlle, intergranular, and faceled lracture surfaces of duplicate specimen of neutron absorber tube labricated from HP heat HP3O4 CD and Irradlated $10=2 \times 10^{21}$ H.c. ${ }^{2}$

31. Characteristic $59 \mathrm{eV}$ Auger electron peaks obtalned from several SSs 
32. Comparison of Intensitles of $\approx 59 \mathrm{eV}$ Auger electron peak obtained from several types of nonirradlated steels elther asrecelved or corroded in liquid $\mathrm{Ll}$ at $600^{\circ} \mathrm{C}$ for $144 \mathrm{~h}$

33. Relative grain-boundary concentrations of alloying and impurity elements in HP3O4 A and HP3O4 CD absorber tube specimens Irradlated to $\approx 2 \times 10^{21} \mathrm{n} \cdot \mathrm{cm}^{-2}$

34. Crack growth rates vs. maximum stress intensily for $\mathrm{Cr}-\mathrm{Ni}$ plated $\mathrm{A} 533-\mathrm{Gr} \mathrm{B}$ steel in $\mathrm{HP}$ ox genated water at $289^{\circ} \mathrm{C}$ at rise times of $12-400 \mathrm{~s}$ at $\mathrm{R}=0.9$

35. Crack growth rates vs. maximum stress intensity for $\mathrm{Cr}-\mathrm{NI}$ plated $\mathrm{A533}-\mathrm{Gr} \mathrm{B}$ steel in $\mathrm{HP}$ oxygenated water at $289^{\circ} \mathrm{C}$ at rise times of 75 and $1500 \mathrm{~s}$ at $\mathrm{R}=0.9$.

36. Crack growth rates vs, rise lime for $\mathrm{Cr} N \mathrm{~N}$ plated $\mathrm{A} 533 \mathrm{Gr} \mathrm{B}$ steel at $\mathrm{R}=0.9$ in $\mathrm{HP}^{\mathrm{P}}$ oxygenated water at $289^{\circ} \mathrm{C}$

\section{Tables}

1. Chemical composition of ferritic steels used for fatigue tests. 6

2. Average room-temperature tensile properties of ferritic steels. 6

3. Faligue test results for A106 Gr B steel at $288^{\circ} \mathrm{C}$ 10

4. Fatigue test results for $A 533-$ Gr $B$ steel at $288^{\circ} \mathrm{C}$ 11

5. Chemlcal composition and ferrite content of cast SSs for corrosion faligue tests in simulated BWR water.

6. Crack growth results for $\mathrm{CF} 8 \mathrm{M}$ and $\mathrm{CF} 8$ cast SS $1 \mathrm{~T}$-compacttension spectmens under cyclic loading in $289^{\circ} \mathrm{C}$ water.

7. Summary of crack growth results for cast SS specimens at dufferent load ratlo and stress intenslly values in $289^{\circ} \mathrm{C}$ water.

8. Tensile propertles of wrought and cast SSs at $289^{\circ} \mathrm{C}$

9. Chemical composition and fluence of HP and CP Type 304 SS BWR components

10. Effect of frequency on crack growth of A533-Gr B and A106-Gr B 1T-compact-tension specimens in $289^{\circ} \mathrm{C}$ water contalning $\approx 200-300 \mathrm{ppb}$ DO 
Fatigue of Ferritic Pipting and Pressure Vessel Steels

Plain carbon steels are used exlenslvely In I'WR and BWR nuclear steam supply systems as piping and pressure vessel materials. The steels of interest for these applications Include A106-Gr B and A333-Cir 6 for seamless plpe and A302-Gr B, A508-2, and A533-Gr B plate for pregsure vessels. Additional fallgue tests were conducted on mediumsulfur-content A106 Gr B plping and A533 Gr B pressure vessel steels in simulated PWR water and in air. The fatlgue life of A533 Cir B steel in deoxygenated water is generally shorter by a factor of 2 than that in alr. No slgnllicant effect of the aqueous environments was observed in tests on A $106-$ Gr B steel. The effects of load shape and loading rate will be further explored in subsequent lesting.

Enutronmentally Assisted Cracking of cast Stamless Ste'ls

Additional crack growth rate (C(iR) lests have been conducted on fracture-mechantes specimens of CF 8 , and $\mathrm{CF} 8 \mathrm{M}$ grades of cast stalnless steel (SS) in as-recelved and thermally aged condfitons to characterlye envirommental. loading, and materal conditions that can produce susceptibllity to stress corroslon cracking (SCC) in these steels. The CGRs in high-purlty water contalning 0.2 and 58 ppm dissolved oxygen were compared with predictions found in Section XI of the ASME code for wrought SS in alr and wilh modified correlatlons for wrought SSs in waller. The results malicate that the air curve is frequently nonconservative, but for the most part. the datat are bounded by the modilted correlations for wrought SSs in water at $289 \mathrm{C}$. Thermal aging increases the yleld and ultumate strengths of the steels. and the CCRs in water tend to inctease with the square of the yield stress of the matertals.

Irradiation-Assisted Stress Corrosion Cracking of Type 30.4 SS

Fallures of austentic SS after accumulation of high huchere have been altributed to radiation induced segregallon (RIS) or depletion of elements such as SI, P, S. NI, and Cr. However, the exact Identity of the elements that segregitle and the degree to which RIS produces susceptibllity of the corc thtermal compontents of l.WRs to irradlation asststed SCC are unclear. Slow stran rall lenslle (SSIRl) lesls and grain boundary analyses by Auger electron spectroscopy (ALS) were conducted on high and commerctal purity (HIP and $C P$ Type 304 sS specimens from thradiated BWR components. Contrary to previous bellefs. susceptubllity to fntergramulat stress corruston cracklng (IGSCC) could not be correlated with RIS of impurilies such ats SI. P. C, or S. but a correlation was obtained with grain boundary $\mathrm{Cr}$ concent ratlon, Indlialling thall $\mathrm{Cr}$ depletlon plays a role. However, graln boundary concentrattons of $\mathrm{Cr}$ determined from presently avallable fleld emisston gun/scanning transmission electron mletoscopy/energy disperslve spectroscopy (FEG STEM EDS) and AES lechnigues are nol alcomalle enough lo clarlfy the importance of $\mathrm{Cr}$ depletion. Caran boundary analyses were condurled on BWR neutron absorber tubes that were fabricated from lwo III heals of type 30.4 ss that had virtually fdentleal chemfeal

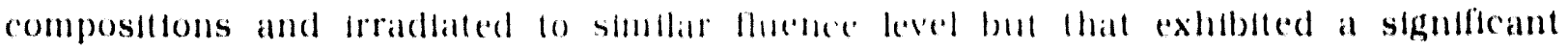

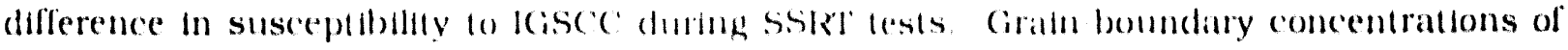
Cr. NI. S1, P. S, and C of the reststiant and susceplible heals were virtually identleal. 
However. gratn boundarles of the resistant malletial contalued a lower concentration of $N$ and higher concentratlons of $B$ and hi than those of the slisceplible material.

Bornn is known 10 undergo thermal segregation 10 grain boundarles in austenille SSs. Therefore, grain boundary concentratlons of $\mathrm{B}$, and hence L, could be influenced strongly by thermomechanical processes even if core internal components are fabricated from the same starting material. During slow cooling of thicker sectlons (e.g. BWR top gulde), thermal segregation of $B$, and hence l.I. Is likely to be more pronounced. This will be conducive to suppresston of IASCC under conditions of a simflar thermal sensitization (1.e.. Cr depletion). The present study indleates that a synergism between graln-boundary segregation of $N$ and $B$ impurites and transmutallon by thermal neutrons $10 \mathrm{H}$ and L.l. respectively, plays an Important role in IASCC. However, the relative Importance of the roles of grain-boundary $\mathrm{Cr}$ depletion and the concentrallons of $N$, B, and $L$ on grain boundaries is not yel clear.

\section{Stress Corrosion cracking of Ferrilic Sleels}

Addilonal fracture mechanles CGR tests have been performed on nonplated specimens of A106-Gr B and A533 Cir B steel and on a specimen of A533-Gr B plated with $\mathrm{Ni} \mathrm{Cr}$. The effect of frequency on CGR was determined at a load rallo of 0.9 in HP oxygenated $(\approx 200 \mathrm{ppb})$ water at $289{ }^{\circ} \mathrm{C}$. The CGRs for the $\mathrm{NI} \mathrm{Cr}$ plated A533-Gr B specimen were compared wilh predicted values from new correlatlons proposed for Inclusion in Secton $\mathrm{XI}$ of the ASME Buller and Pressure Vessel Code. The observed CGRs were adecuately bounded by llae proposed ASML: Section XI correlations. 


\section{Introduction}

Fatigue and environmentally assisted cracking (EAC) of plping, pressure vessels, and core components in light water reactors (L.WRs) are Important concerns as extended reactor lifetimes are envisaged. The degradatlon processes in U.S. reactors include fatigue of austentic stainless steel (SS) in emergency core cooling systems' and pressurlzer surge line" plping in pressurized water reactors (PWRS). Intergranular stress corrosion cracking (IGSCC) of austenttic SS piping in boiling water reactors (BWRs), and propagation of fatigue or stress corrosion cracks (which inllate in sensitized SS cladding) into low alloy ferritic steels In BWR pressure vessels." Simllar cracking has also occurred in upper shell-toIransltion-cone girth welds in PWR steam generator vessels, ${ }^{+}$and cracks have been found In steam generator feedwater distribution piping. ${ }^{++}$Occurrences of mechantcal-vibrationand thermal-fluctuation-Induced latigue fallures in L.WR plants in Japan have also been documented. 1 Another concern is fallure of reactor-core internal components after accumulation of relatively high lluence, which has occurred in both BWRs and PWRs. The general pattern of the observed lillures Indicales that as muclear plamts age and the neutron nuence increases, many apparenlly nonsensllized anslenille malerials become susceptible to Intergranular fallure by a degradillon process combonly known as Irradlation assisted stress corrosion cracking (IASCC). Some of these fillures have been reported for compo. nents subjected to relatlvely low or neglighble slress levels, e.f., control blade sheaths and handles and instrument dry tubes of BWRs. Although most latled components can be replaced. some safely significant struclural components, such as the BWR lop gulde. shroud, and core plate, would be very difleull or impractloal to replace. Research during the past slx months has locused on (a) lillgule of lerrltic steels used in plping. steam generators, and pressure vessels; (b) EAC of cast anstenttic SSs; (c) IASCC in high- and commerclal purity (HIP and CP) Type 304 SS speedmens from control blade absorber lubes and a control blade sheath used in operalling BWRs; and (d) EAC of forritie steels.

\section{Fatlgue of Ferritic Steels}

Plaln carbon and low alloy sleels are used exlenslvely in PWR and BWR steam supply systems as plping and pressure vessed malertals. The slects of laterest in these applications include 1106 Gr B and A3333 (ir 6 lor seamless plpe and A.302 Cor B, A508 2. and A533 Gr B plate for pressure vessels. The ASME Code Section III (Division 1, Subsection NB) Includes rules for the constructlon of muclear power plant Class 1 components. It recognizes fallgue as a posslble mode of liblure in pressure vessel steels

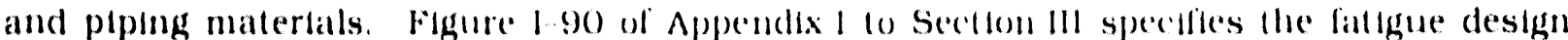
curves for the applicable struclural materials. The correnl code deslgu curves are based

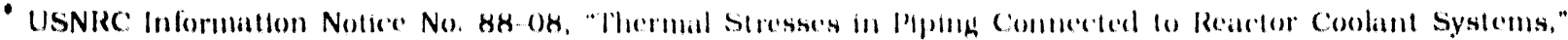
June 22. I988; Supplement 1. Jume 24, 1988; Supploment 2. August 4, IG86; Supplement 3, Apmi 11, 1989.

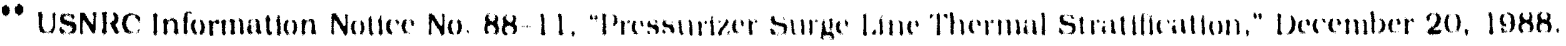

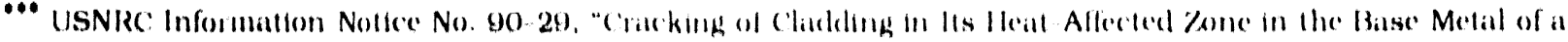
Reactor Vessel llond," April 30, 1990.

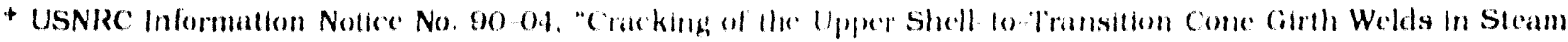
Generutors." January, 26, 1090.

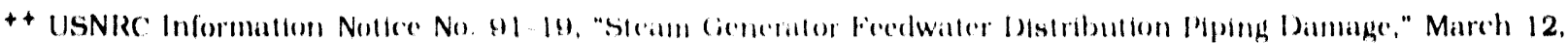
|no|.
} 
primarily on strain-contuolled fallgue tests of small pollshed specimens in air at room temperature. 2 To obtain the Code fallgue deslgn curves, best-fil curves to the experimental data were decreased by a factor of 2 on stress or a factor of 20 on cycles, whichever was more consenative at each polnt. The lactors were intended to account for uncertaintes in translating the experimental data of laboratory test specimens to actual reactor components. The factor of 20 on cycles is the product of three subfactors: 2.0 for scatter of data (minimum to mean). 2.5 for size effects, and 4.0 for surface finish, atmosphere, etc. ${ }^{3}$ "Almosphere" was intended to reflect the effects of an industrial environment rather than the controlled environment of a laboratory. The effects of the coolant environment are not explictly addressed in the Code design curves.

Recent fatigue straln vs. LIfe (S/N) data from the U.S. 40 and Japan $11-13$ Illustrate potentlally significant effects of LWR enviromment on the faligue resistance of carbon and low-alloy steels. In some cases, fallures were observed below the ASME Code fallgue design curve. These results ralse the issue of whether the fallgue design curves in Section III are approprlate for the purposes intencled and whether they adequaltely account for environmental effects on fatigue behavior. The factors of 2 and 20 applied to the meandata curve may not be as conserva!tve as ortginally intended.

The primary sources of U.S. data on latigue of ferrltic steel in LWR environments are the data obtalned by General Electric $\mathrm{Co}$. (GE) In a lest loop at the Dresden 1 reactor, ${ }^{4.5}$ tests performed by GE/Electric Power Research Instltute (EPRI), ${ }^{6}$ and the work of Terrell.7.8 Nearly all these data are on carbon steels. The data from Japan have been complled in the data base JNUFAD" for "Fallgue Strenglh of Nuclear Plant Components." The results for A508 Cl 3 low alloy steel and A333 Gr 6 carbon steel have been published by Higuchl and IIda 11 and llda et al.12 and for forged A508 Cl 3 and rolled A533-Gr B lowalloy steels by Nagala et al. ${ }^{13}$

Several trends are clear from the avallable $S / N$ data. The magnilude of the decrease in fatigue life depends on the alloy composilton, temperature, and conceatration of dissolved oxygen (DO) in the water. At the very low DO levels characteristle of PWiis and BWRs wilh hydrogen/water chemistry. envirommental effects on latigue life are modest at all temperatures and strain rates. Fatlgue life decreases rapidly as DO increases over a rather narrow range of $=0.1 \cdot 0.3 \mathrm{ppm}$, but further increases up $108 \mathrm{ppm}$ cause only a modest decrease in llfe. In oxygenaled waler. latlgue life strongly depends on temperature and strain rate. At a glven strain rate, faligue life increases by a factor of 5 or more as the temperature is decreased from $28810200^{\circ} \mathrm{C}$, For the same environment and strain range. fatugue lives can be decreased by a faclor of $=50$ by reduclug the strain rate from 0.1 to $0.0001 \% / \mathrm{s}$. Limited data indicate that only the tensile strain rates (strain rate during the tensile half of the strain cycle) are important in environmentally assisted reduction in fatigue life. Based on the existing $S / N$ data, Argonne Nattonal Laboratory (ANL) has developed interim faligue design curves that lake into account temperature, DO level in the water, sulfur level in the steel. and strain rate. 14

\footnotetext{
- Private communication from M. Illgucht, Ishikawajima- llarima llcavy Industrles Co., Japan, to M. Prager of the Pressure Vessel Research Council IIVRO, January 1992. "The old dalabase "FADAl," has been revised and renamed "JNUFAD."
} 
The $\mathrm{S} / \mathrm{N}$ data on carbon and low-alloy steels in water, however, are somewhat limited and do not cover the range of loading conditions found in actual reactor operation. For example, virtually all data in LWR water are at relatively high strain ranges. Furthermore. environmental effects on crack initiation have been considered as a possible mechanism for the reduction in fatigue life. 11,12 High-sulfur steels are more susceptible because cracks can initiate at surface micropits that form near manganese sulfide (MnS) inclusions. Effects of crack initiation are important only at low strain ranges, where experimental data are not avallable. At high strain ranges, fatigue life is dominated by crack propagation.

The data also do not extend over the range of strain rates normally encountered in service; e.g., some transients may have strain rates as low as $0.00001 \% / \mathrm{s}$. Extrapolation of avallable data to such low values would predict a reduction in fatigue life by a factor of $>300$. The relatively good service experience of carbon steel piping in BWRs, 1.e., $288^{\circ} \mathrm{C}$ water with $0.2 \mathrm{ppm}$ DO, suggests that the effect of strain rate on fatigue life must saturate at some level, although no such saturation has been observed experimentally. The JNUFAD data show that environmental effects on fatigue life are greater for carbon steel than for lowalloy steel. 11 However, most low-alloy steels that have been investigated in JNUFAD are low-sulfur heats $(<0.007 \mathrm{wt} . \%)$. It is likely that differences between carbon and low-alloy steels are caused by the sulfur content of the steels and that compositional or structural differences have only minor effects on fatigue life.

\subsection{Technical Progress (O. K. Chopra, W. F. Michaud, and W. J. Shack)}

The objectives of this task are to (a) conduct fatigue tests on carbon and low-alloy steels under conditions where information is lacking in the existing $S / N$ data base, (b) establish the effects of material and loading variahles on environmentally assisted reduction in fatigue life, and (c) validate and update the proposed interim fatigue design curves. Fatigue tests are being conducted on A106-Gr B carbon steel and A533-Gr B lowalloy steel in water and in air at $288^{\circ} \mathrm{C}$. Initial results have been presented earlier. 9.10 For both carbon and low-alloy steels, environmental effects are modest in PWR water at all strain rates. The experimental effort during the present reporting period focused on the effects of strain rate and alloy composition on fatigue life in simulated BWR water. Several fatigue tests were completed on A106-Gr B and A533-Gr B steels at $288^{\circ} \mathrm{C}$ in water containing $\approx 0.8 \mathrm{ppm}$ DO to confirm the strong effect of strain rate on fatigue life and to determine whether the strain-rate effect saturates at very low values.

\subsubsection{Experimental}

Low-cycle fatigue tests are being conducted on A106-Gr B carbon steel and A533-Gr B low-alloy steel with an MTS closed-loop electrohydraulics machine. The A533-Gr B material was obtained from the lower head of the Midland reactor vessel, which was scrapped before the plant was coripleted. The A106-Gr B material was obtained from a 508-mm-diameter schedule 140 pipe fabricated by the Cameron Iron Works. Houston. TX. The chemical compositions of the two materials are given in Table 1, and average roomtemperature tensile properties are given in Table 2. Microstructures of the steels are shown in Fig. 1; carbon steel has a pearlitic structure, whereas the low-alloy steel consists of tempered bainite. Smooth cylindrical specisnens with $9.5-\mathrm{mm}$ diameter and $19-\mathrm{mm}$ 
Table 1. Chemical composition (wt.\%) of ferritic steels used for fatigue tests

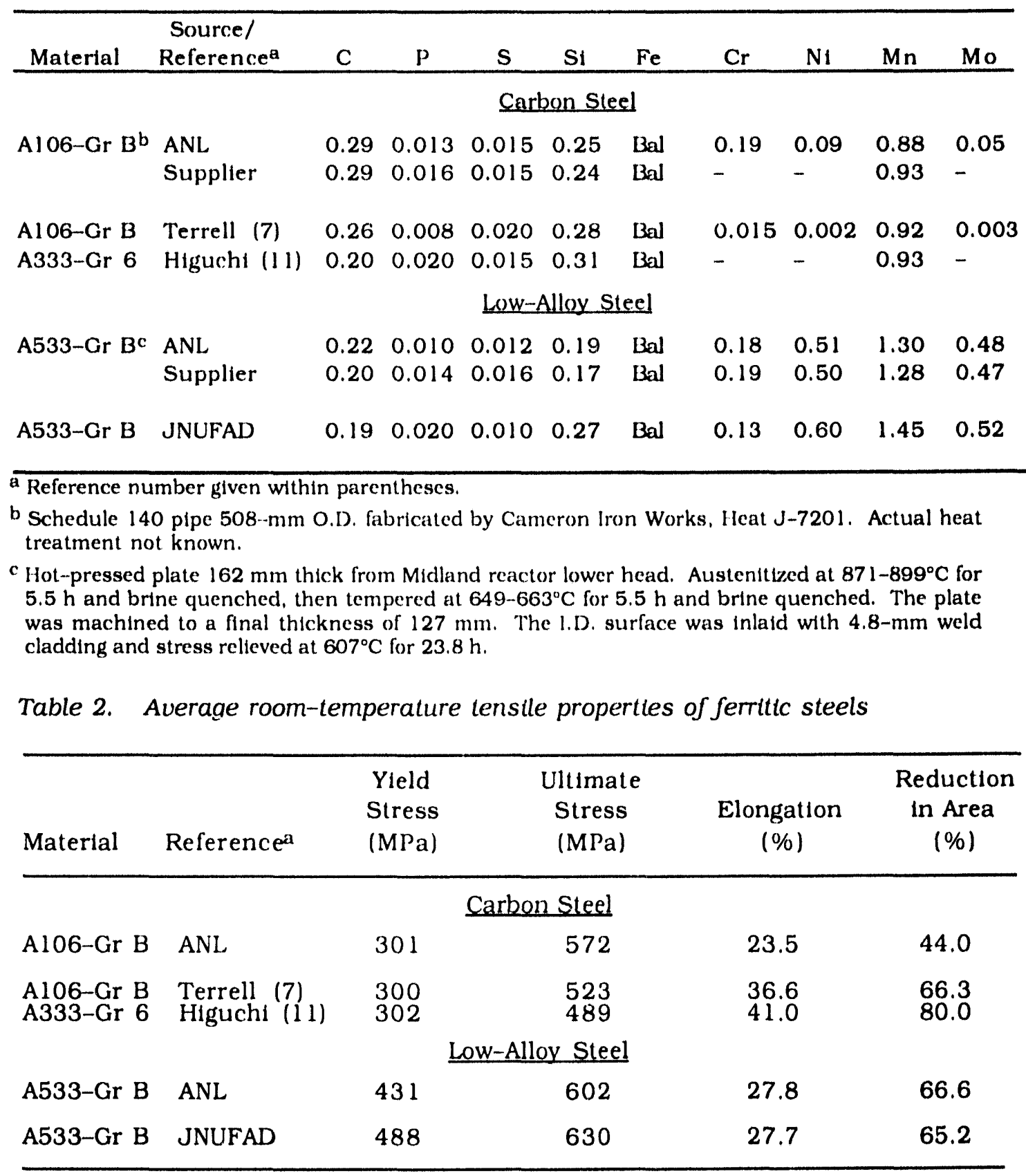

a Reference number given within parentheses.

gage length were used for the fatigue tests (Fig. 2). Specimen gage length was given a $1-\mu \mathrm{m}$ surface finish in the axial direction to prevent circumferential scratches that might act as sites for crack initiation.

Tests in water were conducted in a small autoclave with an annular volume of $12 \mathrm{~mL}$ (Fig. 3). A schematic representation of the system is shown in Fig. 4. The once-through system consists of a 132-L supply tank, Pulsafeeder ${ }^{\mathrm{TM}}$ pump, heat exchanger, preheater, and the autoclave. Water is circulated at a rate of $\approx 10 \mathrm{~mL} / \mathrm{min}$ and a system pressure of 


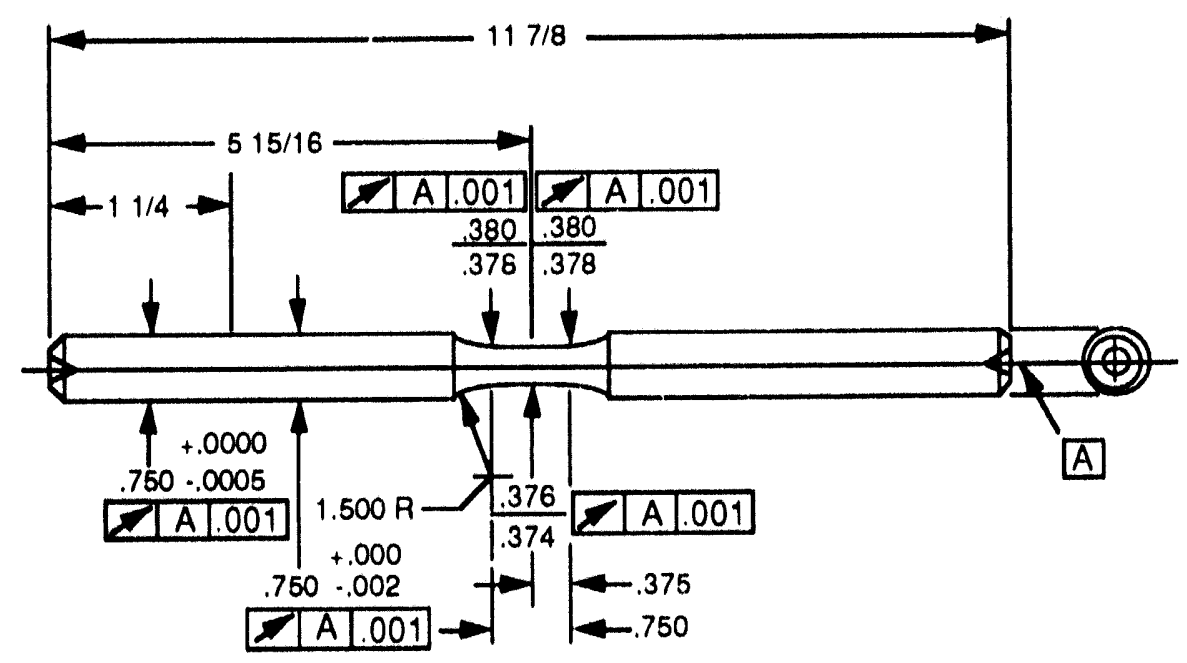

Figure 1, Configuration of fatigue test specimen (all dimenstons in thches)

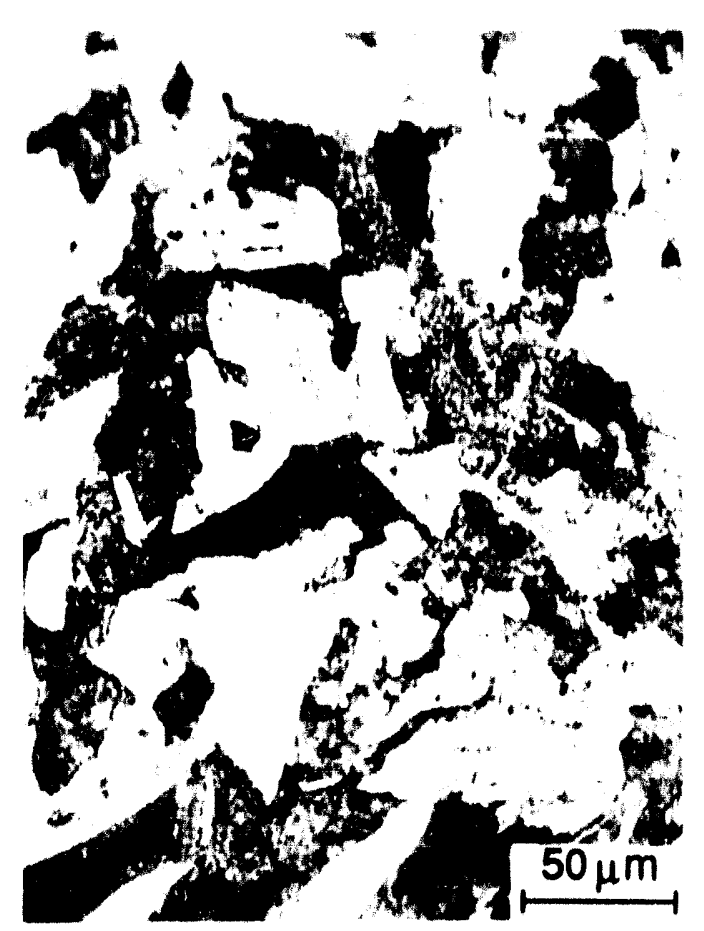

(a)

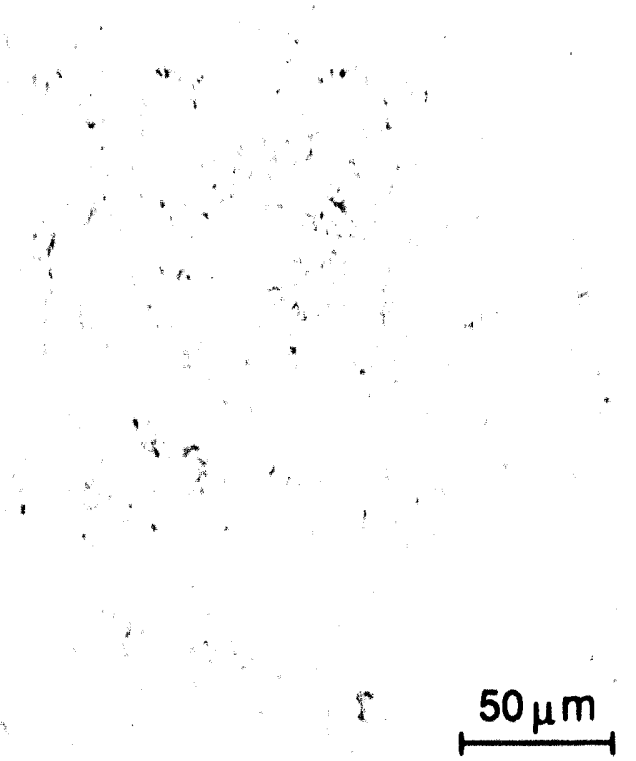

(b)

Figure 2. Microstructures of (a) A106-Gr B carbon steel and (b) A533-Gr B low-alloy steel

$9 \mathrm{MPa}$. The autoclave is constructed of Type 316 SS and contains a tltanium liner. The supply tank and most of the low-temperature plping are Type 304 SS; titanlum tublng is used in the heat exchanger and for connections to the autoclave and the electrochemical potential (ECP) cell. The ECPs of platinum and an electrode constructed of the same material as the fatigue specimen were montored during the test against an $0.1 \mathrm{M} \mathrm{KCl} / \mathrm{AgCl} / \mathrm{Ag}$ external relerence electrode. An Orbisphere meter and CHEMetries ${ }^{\mathrm{Mm}}$ ampules were used to measure the $\mathrm{DO}$ ) concentrations in the supply and effluent water. 


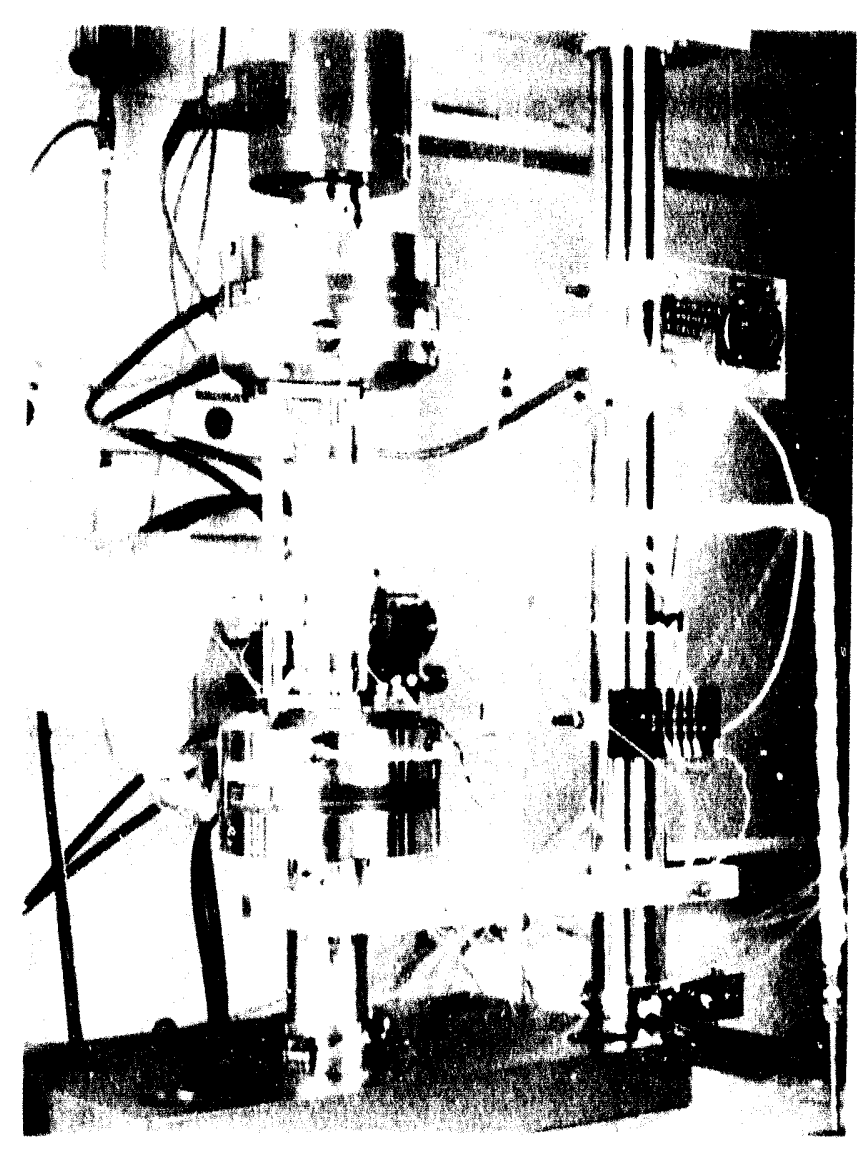

Figure 3. Autolate system for faligne tests in water

All tests were conducted at $288 . \mathrm{C}$ with fully reversed axlal loading (1.e. strain ratio $\mathrm{R}=-1$ ) and a trangular or sawtooth wave form. Unless otherwise mentloned, the strain rate for the trangular wave and fast loading half of the sawlooth wave was $0.4 \% / \mathrm{s}$. Tests In water were performed under stroke control where the specinen strain was controlled between two locations outside of the autoclave. The lixture and linear-voltage-differential transducer (LVDT) for stroke control can be seen to the left of the antoclave in Fig. 3. Tests in air were performed under strain control wilh an axlal extensometer; specimen strain between the two locattons used in the water lests was also recorded. Information from the atr tests was used to determine actual strain in the specimen gage length for tests in water.

Simulated BWR water containing $=0.8 \mathrm{ppm}$ DO was prepared by bubbling nitrogen containing 1-2\% oxygen through delonked water in the supply lank. Water samples were taken periodically to measure the $\mathrm{pH}$, resistivity, and DO concentration. After the desired concentration of DO was achleved. the nitrogen/oxygen gas mixture was maintalned on the supply tank at a $20-\mathrm{kPa}$ overpressure. Simulated PWR water was formulated by dissolving boric acld and lithlum hydroxide in 20 l. of delonized water before adding the solution to the supply tank. The DO in detonized water was reduced to $<10 \mathrm{ppb}$ by bubbling nitrogen through the water. A vacuum was drawn on the lank cover gas to speed deoxygenation. After the DO was reduced to the desired level, a $20 \mathrm{kPa}$ overpressure of hydrogen was malntalned to provide $=2 \mathrm{ppm}$ dissolved hydrogen in the deoxygenated feedwater. 


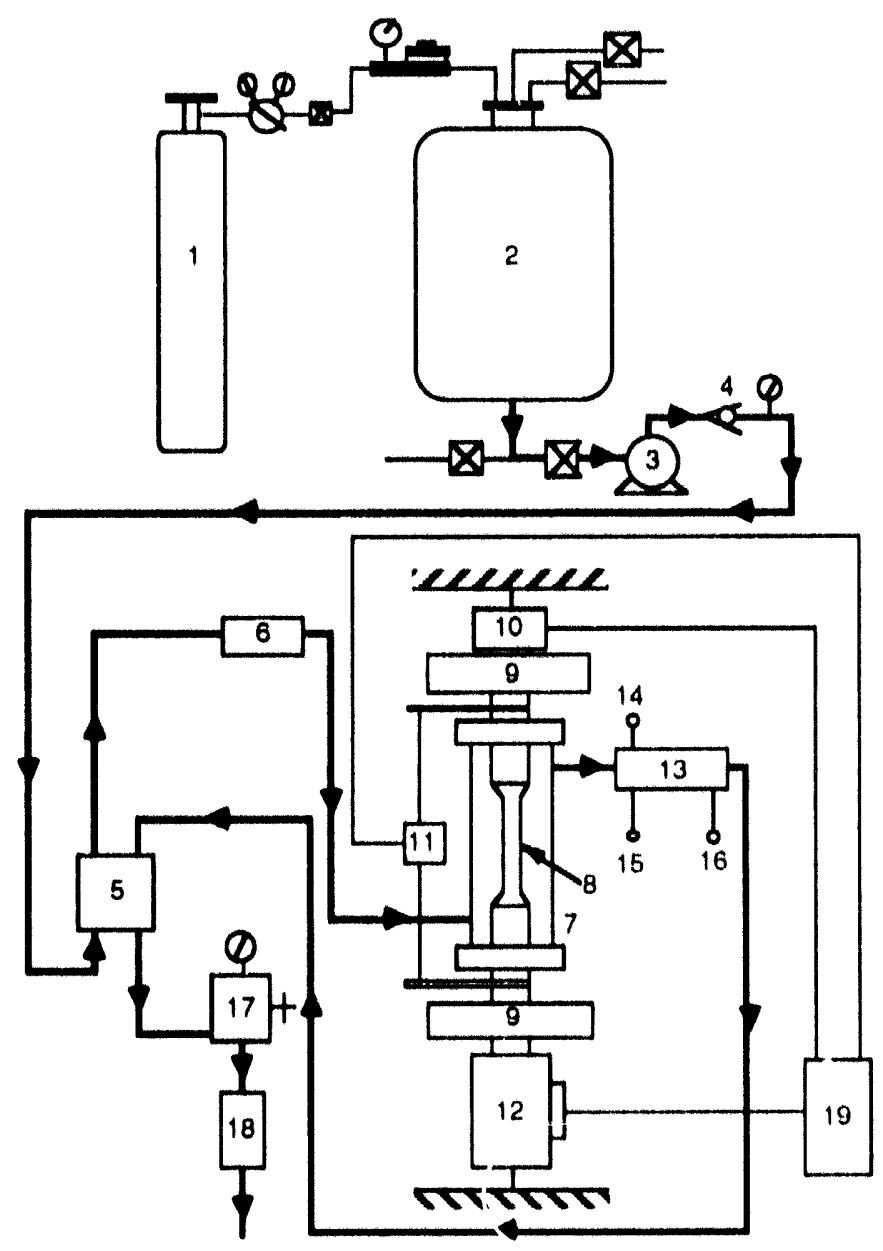

1. Cover gas supply tank

2. Water supply tank

3. Mulsileceler high-pressure pump

4. Check value

5. Ileat exchanger

6. Preheat exchanger

7. Pipe antoclave

8. Fallgue test specimen

9. Mis hydraulic collet grips

10. Mis load cell

11. Displacement LVDT

12. MIS hydratilic actuator

13. ECP cell

14. Matinum clectrode

15. Sperimen electrode

16. Reference electrode

17. Mity Mite bitck-pressure regulator

18. Orbisphere dissolved oxygen meter

19. Mi's clectrohydratulic controls

Figure 4. Schematic diagrain of autoclave system for fatigue tests in water environment

\subsubsection{Results}

The fatigue results on $\mathrm{A} 106 \mathrm{Gr} B$ and $\mathrm{A} 533-\mathrm{Br} B$ steels are summarized in Tables 3 and 4 , respectively. The latigue $11 \mathrm{l} e . \mathrm{N}_{25}$. corresponds 10 the number of cycles for a $25 \%$ decrease in tensile stress amplitude. The total strain range vs. Fatigue life curves for the carbon and low alloy steels in alr are shown 11 Figs. 5 and 6 . Results from other Investlgations8.11 on simllar steels with comparable composilion, in particular the sulfur content, and the ASME Section III mean datat curves are also included in the figures.

The results indicate that for both steels, straln rate has no eflect on fatlgue life in alr. The data for A106 Gr B steel are in excellent agreement with results obtained by Terrell7,8 on Al06 Gr B steel, bul are lower by a lactor of $\approx 5$ than those obtalned by Higuchl and Ildall on A333-Gr 6 steel. Also, the data for A106 Gr B steel are below the ASME meandala curve for carbon steel at room temperature at high straln range (by a factor of 3), but are above the ASME mean curve at low straln range. The results for A533-Gr B steel show good agreement with the JNUFAD data on A533 (ir B steel and the ASME mean data curve for low alloy steel at room temperalure. 
Table 3. Fallgue test results for A106-Gr B steel at $288^{\circ} \mathrm{C}$

\begin{tabular}{|c|c|c|c|c|c|c|c|c|c|c|}
\hline $\begin{array}{l}\text { Test } \\
\text { Number }\end{array}$ & $\begin{array}{l}\text { Environ } \\
\text { ment }\end{array}$ & $\begin{array}{l}\text { Dissolved } \\
\text { Oxygen } \\
\text { (ppb) }\end{array}$ & $\begin{array}{c}\mathrm{pH} \\
\text { at } 25^{\circ} \mathrm{C}\end{array}$ & $\begin{array}{c}\text { Cond. } \\
\left(\mu S \cdot \operatorname{com}^{-1}\right)\end{array}$ & Controla & $\begin{array}{c}\text { Tenslle } \\
\text { Rate } \\
(\% / s)\end{array}$ & $\begin{array}{c}\text { Comp. } \\
\text { Rate } \\
(\% / s)\end{array}$ & $\begin{array}{l}\text { Stress } \\
\text { Range } \\
\left(\mathrm{M} P^{\prime} \mathrm{a}\right)\end{array}$ & $\begin{array}{l}\text { Strain } \\
\text { Range } \\
(96)^{2}\end{array}$ & $\begin{array}{c}\text { Life } \\
N_{25} \\
\text { (Cycles) }\end{array}$ \\
\hline 1498 & Alr & - & - & - & Straln & 0.4 & 0.4 & 1001.4 & 1.004 & 1,048 \\
\hline 1553 & Alr & - & - & .. & Strain & 0.4 & 0.4 & 921.1 & 0.757 & 3.253 \\
\hline 1615 & Alr & - & - & - & Strain & 0.04 & 0.4 & 959.8 & 0.755 & 3.873 \\
\hline 1609 & Air & - & -. & - & Strain & 0.004 & 0.4 & 1026.0 & 0.756 & 3.721 \\
\hline 1543 & Alr & -- & - & - & Straln & 0.4 & 0.4 & $8: 8.2$ & 0.502 & 14,525 \\
\hline 1619 & Alr & - & - & - & Struin & 0.4 & 0.4 & $74: 7$ & 0.401 & 37,142 \\
\hline 1621 & Alr & - & -- & - & Straln & 0.01 & 64 & 787.1 & 0.403 & 38,128 \\
\hline 1550 & Alr & - & - & -- & Strain & 0.4 & 0.4 & $68: .7$ & 0.353 & 66,768 \\
\hline 1552 & Alr & - & - & - & Strain & 0.4 & 0.4 & 680.6 & 0.352 & 93,322 \\
\hline 1644 & Alr & - & - & - & Straln & 0.004 & 0.4 & 702.0 & 0.364 & $>95.000$ \\
\hline 1546 & Alr & - & - & - & Stroke & 0.4 & 0.4 & 975.7 & 0.916 & 1.365 \\
\hline 1612 & Alr & - & - & - & Strok: & 0.004 & 0.4 & 1008.2 & 0.779 & 3,424 \\
\hline 1554 & Alr & - & - & - & Stroke & 0.4 & 0.4 & 896.8 & 0.730 & 3,753 \\
\hline 1548 & Alr & - & - & $\ldots$ & Stroke & 0.4 & 0.4 & 831.9 & 0.545 & 10.632 \\
\hline 1555 & Air & - & - & - & Stroke & 0.4 & 0.4 & 676.3 & 0.343 & 98,456 \\
\hline 1547 & PWRb & 8 & 6.7 & 23.3 & Stroke & 0.4 & 0.4 & 1010.9 & 0.987 & 692 \\
\hline 1564 & PWRb & 12 & 6.6 & 21.7 & Stroke & 0.4 & 0.4 & 942.0 & 0.769 & 1.525 \\
\hline 1549 & PWRb & 8 & 6.7 & 25.6 & Stroke & 0.4 & 0.4 & 827.0 & 0.533 & 9.396 \\
\hline 1560 & PWRb & 12 & 6.6 & 23.7 & Stroke & 0.4 & 0.4 & 701.3 & 0.363 & 35.100 \\
\hline 1556 & PWRb & 8 & 6.6 & 22.7 & Stroke & 0.4 & 0.4 & 710.9 & 0.360 & 38.632 \\
\hline $\begin{array}{l}1632 \\
1614\end{array}$ & $\begin{array}{l}\text { BWWR } \\
\text { IBWR }\end{array}$ & $\begin{array}{l}800 \\
400\end{array}$ & $\begin{array}{l}5.8 \\
5.8\end{array}$ & $\begin{array}{l}0.11 \\
0.11\end{array}$ & $\begin{array}{l}\text { Stroke } \\
\text { Stroke }\end{array}$ & $\begin{array}{l}0.4 \\
0.004\end{array}$ & $\begin{array}{l}0.4 \\
0.4\end{array}$ & $\begin{array}{l}913.3 \\
930.4\end{array}$ & $\begin{array}{l}0.740 \\
0.786\end{array}$ & $\begin{array}{r}2.077 \\
303\end{array}$ \\
\hline 1623 & BWW & 800 & 5.9 & 0.08 & Stroke & 0.004 & 0.004 & 943.8 & 0.792 & 338 \\
\hline 1616 & BWWR & 800 & 5.8 & 0.08 & Stroke & 0.0004 & 0.4 & 912.8 & 0.799 & 153 \\
\hline 1620 & IBWTR & 900 & 5.9 & 0.11 & Stroke & 0.00004 & 0.004 & 943.1 & 0.794 & 161 \\
\hline 1634 & BWWR & 800 & 5.8 & 0.16 & Stroke & 0.4 & 0.4 & 733.2 & 0.400 & 19,318 \\
\hline 1624 & BWIR & 800 & 5.9 & 0.10 & Stroke & 0.004 & 0.4 & 775.7 & 0.456 & 2.276 \\
\hline 1639 & BWW & 800 & 5.9 & 0.09 & Stroke & 0.004 & 0.4 & 751.6 & 0.418 & 2951 \\
\hline
\end{tabular}

a Values for stroke-control tests are approximate. Actual strain rates are $\pm 5 \%$ of the listed value.

b Contains 2 ppm lithlum and 1000 ppm boron.

The total strain range vs. latigue life plots for A106-Gr B and A533-Gr B steels in simulated PWR water containing $<10 \mathrm{ppb}$ DO, $1000 \mathrm{ppm}$ boron, and $2 \mathrm{ppm}$ lithlum are shown in Figs. 7 and 8, respectively. The results indicate a marginal effect of PWR water on fatlgue life at high strain ranges. For both steels, fatigue lives in PWR water are up to a factor of 2 lower than those in air at a strain range $>0.5 \%$. Fatigue lives in water and air environments are comparable at a strain range $<0.5 \%$. Limited data on A533-Gr B steel indicate that a decrease in the strain rate by two orders of magnitude does not cause an additional decrease in fatigue life. The results for A106-Gr B steel are consistent with the data obtained by Terrell ${ }^{8}$ in simulated PWR water where no noticeable effect of straln rate or environment on fatigue life was ubserved (Fig. 7). The results are also consistent with the data of Ilda et al. 12 and Prater and Coffin, 15,16 in which the effects of environment were minimal at DO levels of $<100-200 \mathrm{ppb}$.

The effect of oxygenated water $(0.8 \mathrm{ppm} \mathrm{DO})$ on fatigue life of A106-Gr B and A533Gr B steels is shown in Figs. 9 and 10, respectively. The results Indicate that environmental effects depend strongly on strain rate and that only strain rate during the tensile half of a strain cycle is important. The steels show identical behavior; fatigue life 
Table 4. Fattgue test results for A533-Gr B steel at $288^{\circ} \mathrm{C}$

\begin{tabular}{|c|c|c|c|c|c|c|c|c|c|c|}
\hline $\begin{array}{c}\text { Test } \\
\text { Number }\end{array}$ & $\begin{array}{l}\text { Environ } \\
\text { ment }\end{array}$ & $\begin{array}{l}\text { Dlssolved } \\
\text { Oxygen } \\
\text { (ppb) }\end{array}$ & at $25^{\circ} \mathrm{C}$ & $\begin{array}{c}\text { Cond. } \\
\left(\mu S \cdot m^{-1}\right)\end{array}$ & Controla & $\begin{array}{l}\text { Tenslle } \\
\text { Ratea } \\
(\% / s)\end{array}$ & $\begin{array}{l}\text { Comp. } \\
\text { Ratea } \\
(\% / 8)\end{array}$ & $\begin{array}{l}\text { Stress } \\
\text { lange } \\
\text { (MPa) }\end{array}$ & $\begin{array}{c}\text { Struin } \\
\text { Range } \\
(x){ }^{2}\end{array}$ & $\begin{array}{c}\text { Life } \\
N_{25} \\
\text { (Cycles) }\end{array}$ \\
\hline 1508 & Alr & - & - & - & Straln & 0.4 & 0.4 & 910.9 & 1.002 & 3,305 \\
\hline 1515 & Alr & - & - & - & Strain & 0.4 & 0.4 & 866.1 & 0.752 & 6,792 \\
\hline 1625 & Alr & - & - & - & Strain & 0.004 & 0.4 & 887.7 & 0.757 & 4,592 \\
\hline 1508 & Alr & - & - & -. & Straln & 0.4 & 0.4 & 767.6 & 0.501 & 31,200 \\
\hline 1576 & Alr & - & $\ldots$ & - & Strain & 0.004 & 0.4 & 805.8 & 0.503 & 28,129 \\
\hline 1590 & Alr & . & . & . & strain & 0.4 & 0.004 & 821.1 & 0.503 & 24,471 \\
\hline 1640 & Alr & - & - & - & straln & 0.4 & 0.4 & 710.8 & 0.402 & 65,880 \\
\hline 1517 & Alr & - & - & - & Strain & 0.4 & 0.4 & 602.5 & 0.353 & $2,053,295$ \\
\hline$|52|$ & Alr & - & - & - & Stroke & 0.4 & 0.4 & 889.4 & 0.910 & 3.219 \\
\hline 1523 & Alr & . & . & . & Stroke & 0.4 & 0.4 & 898.6 & 0.917 & 2.206 \\
\hline 1522 & Alr & - & - & - & Stroke & 0.4 & 0.4 & 905.4 & 0.800 & 3,419 \\
\hline 1524 & Alr & - & - & - & Stroke & 0.4 & 0.4 & 802.3 & 0.950 & 3,714 \\
\hline 1525 & Alr & - & - & - & Stroke & 0.4 & 0.4 & 743.6 & 0.452 & 65,758 \\
\hline 1538 & Air & - & - & - & stroke & 0.4 & 0.4 & 708.0 & 0.387 & $>1,000,000$ \\
\hline 1526 & DIb & 16 & - & - & Stroke & 0.4 & 0.4 & 876.4 & 0.873 & 3,332 \\
\hline 1527 & Dib & 17 & 6.0 & - & siroke & 0.4 & 0.4 & 752.8 & 0.493 & 10,292 \\
\hline 1528 & Dib & 5 & 5.8 & - & Stroke & 0.4 & 0.4 & 744.1 & 0.486 & 25,815 \\
\hline 1530 & PWIX: & 3 & 6.0 & 41.7 & Stroke & 0.4 & 0.4 & 885.5 & 0.894 & 1,355 \\
\hline 1545 & PWIr: & 8 & 6.8 & 22.7 & stroke & 0.4 & 0.4 & 880.7 & 0.886 & 3,273 \\
\hline 1533 & PWIRE & 4 & 6.9 & 45.5 & stroke & 0.004 & 0.4 & 916.0 & 0.774 & 3,416 \\
\hline 1529 & PWIR" & 3 & 6.0 & 45.5 & Stroke & 0.4 & 0.4 & 743.4 & 0.484 & 31,676 \\
\hline 1588 & PWIR" & 0 & 6.5 & 23.3 & strrke & 0.004 & 0.4 & 826.7 & 0.514 & 15,321 \\
\hline 1605 & PWIRE & 9 & 6.5 & 23.8 & Stroke & 0.4 & 0.004 & 785.2 & 0.460 & $>57.443$ \\
\hline 1539 & PWRE & 8 & 6.8 & 38.5 & siroke & 0.4 & 0.4 & 694.8 & 0.373 & 136,570 \\
\hline 1542 & PWRE & 6 & 6.6 & 27.0 & siroke & 0.4 & 0.4 & 631.8 & 0.354 & $>1,154,802$ \\
\hline 1645 & I3WIR & 800 & 6.1 & 0.07 & stroke & 0.4 & 0.4 & 831.1 & 0.721 & 2.736 \\
\hline 1626 & BWIR & 900 & 5.9 & 0.13 & stroke & 0.004 & 0.4 & 910.1 & 0.788 & 247 \\
\hline 1627 & BWIR & 800 & 5.8 & 0.10 & Stroke & 0.004 & 0.4 & 826.8 & 0.534 & 789 \\
\hline 1641 & BWWIR & 800 & 5.8 & 0.09 & Stroke & 0.4 & 0.4 & 693.0 & 0.374 & 17,367 \\
\hline 1647 & IJWIR & 800 & 6.1 & 0.09 & Stroke & C. 4 & 0.4 & 688.0 & 0.363 & 26,168 \\
\hline
\end{tabular}

a Values for stroke-control lests are approximate. Actual struin rales are \pm 5 ho of the listed value.

b Detonized water.

contains 2 ppm lithlum and 1000 ppm boron.

decreases rapidly with a decrease in strain rate. Compared with tests in alr. fallgue life in oxygenated water is lower by a factors of 2 and 10 at strain rates of 0.4 and $0.004 \% / \mathrm{s}$. respectively. Fatigue tests were conducted on Al06-Gr B steel. at a total strain range of $=0.75 \%$ with a sawtooth wave form and tenslle strain rates between 0.4 and $0.00004 \% / \mathrm{s}$, to establish the effect of strain rate on fatigue life. Relatlve fatlgue llfe, 1.e., ratlo of fallgue life in water to that in alr, is plotted as a funcllon of strain rate in Fig. 11. The results Indicate that the effect of strain rate saturates at $=0.0004 \% / \mathrm{s}$; fallgue life in water is lower by a factor of 20 lower than in air. The results also indicate that only the slow tensilestrain cycle is responsible for environmentally assisted reduction in faligue life. Two fatigue tests on A106-Gr B sleel at a strain range of $\approx 0.75$, one wilh a sawtooth wave form (1.e., 0.004 and $0.4 \% / \mathrm{s}$ strain rates, respectuvely, during the tensile and compressive hall of the strain cycle) and the other with a trlangle wave form $(1 . e .0 .004 \% / \mathrm{s}$ constant st rain rate). show identical fatigue lives (Fig. 9). 

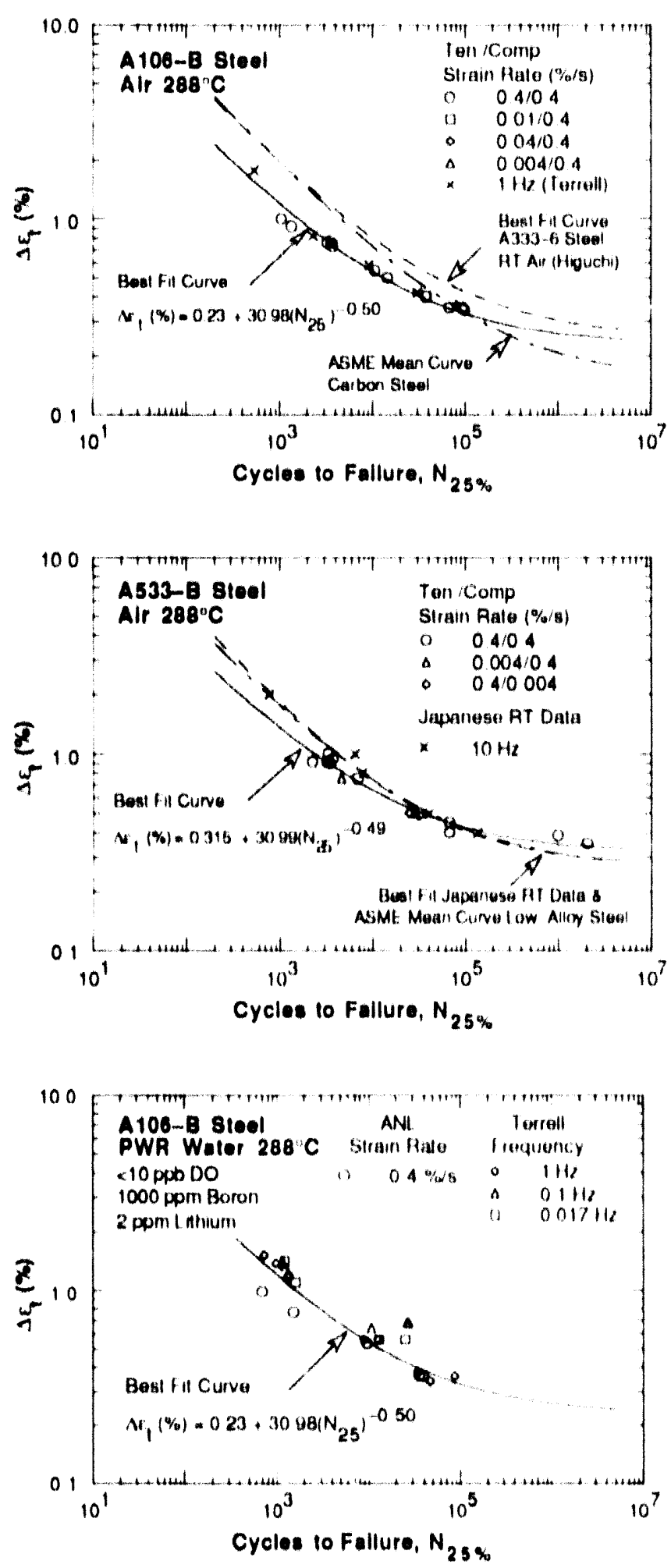

Figure 5.

Total strain range us. fatigue life dala for A 106-Gr B steel in air

Fyoure: 6.

Total strain range us. faligue Iffe clala for A533 Cir $B$ steel in air
Figntre 7

Total strain range us. fatigne life data for 1106 Gr B steel in PWR water at $288^{\circ} \mathrm{C}$ 

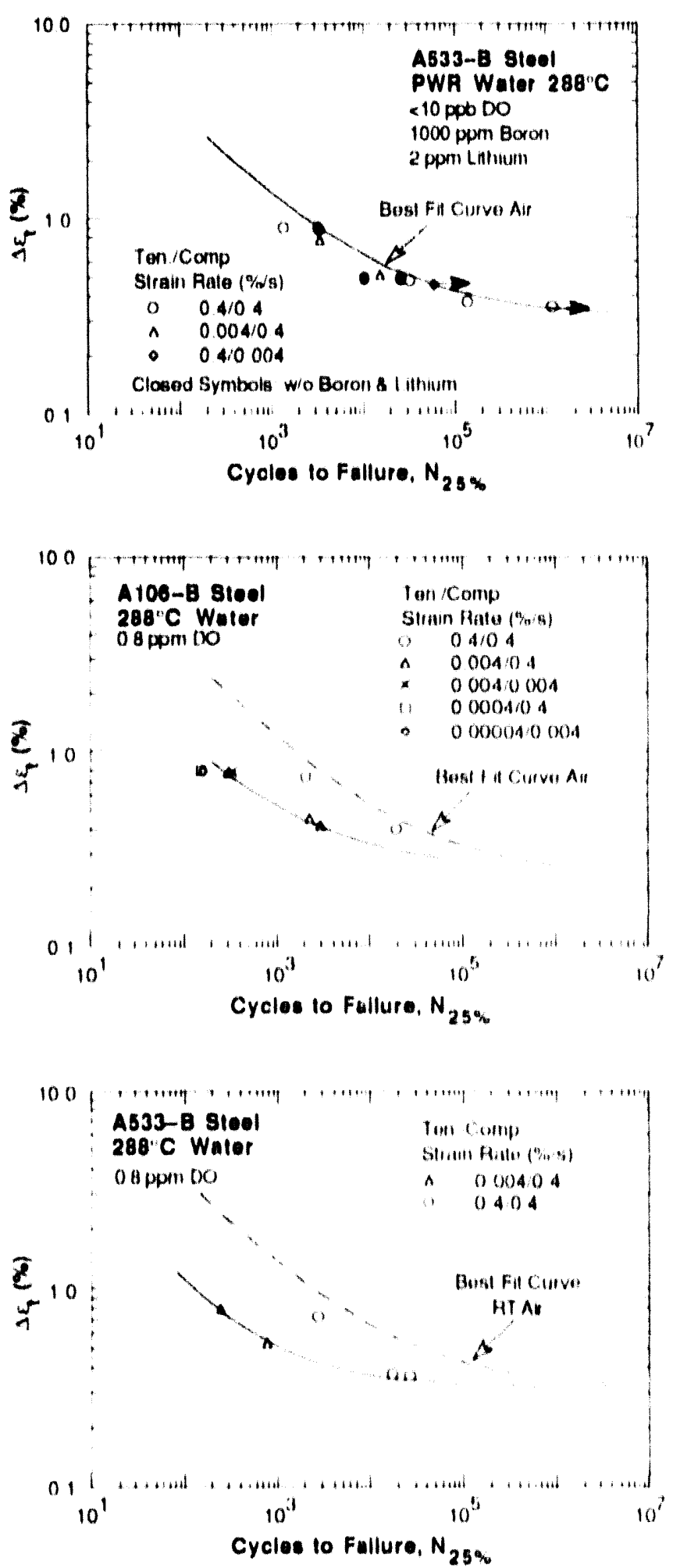

Jignere 8 .

Total strain range us. faligna llfe data for $A 53: 3$ Gi $1 \mathrm{~s}$ steel on PWR water at $288^{\circ} \mathrm{C}:$

Fingle' 9.

Tolal strain ranger lis. fallonice lffe clata

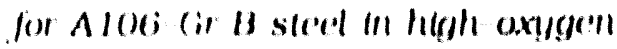
maler al 284 \%
Figures 10.

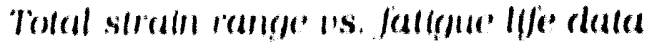

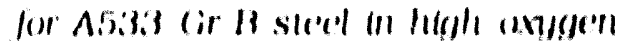
mall al 2ake? 


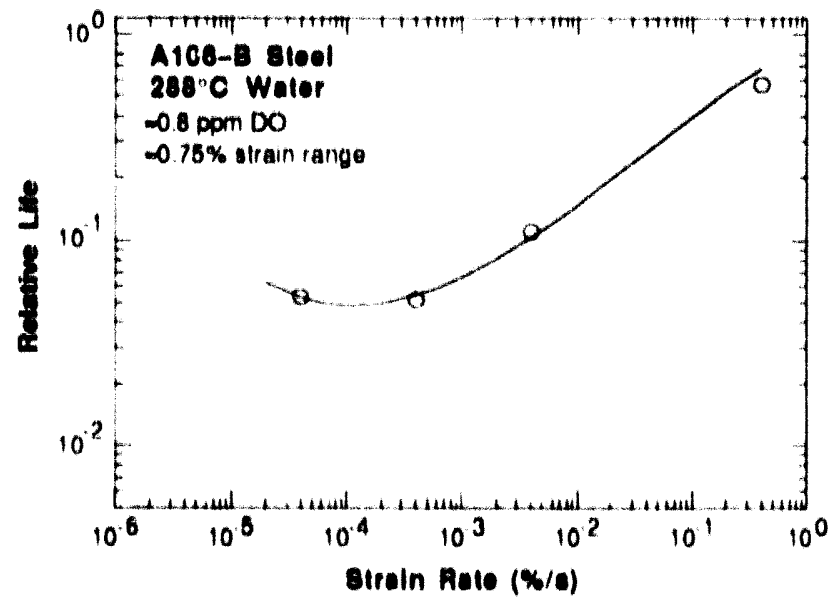

Figure 11.

Elfect of strain rate on fatigue lfe of Al06-Gr B steel in high-axygen water at $288^{\circ} \mathrm{C}$. Relattue l(fe is the rallo of faltgue life in water to that in air.

Plots of cyclic stress range vs. fatlgue cycles for A 106-Gr B and A533-Gr B steels tested in air at $288^{\circ} \mathrm{C}$ and a tolal strain range of $=0.75 \%$ are shown in Figs. 12 and 13. respectively. The cyclic strain-hardening behavior of the steels is consistent with their microstructure. The A106-Gr 13 steel, with a pearlitic structure and low yleld stress, exhlblts rapld hardening during the inllail 100 cycles of latigue lire. The extent of hardening increases with applied straln range. The A106 Gr B carbon steel also shows significant dynamic strain aging. e.h. cyclic stress increases throughout the test. Fatigue strength of the material increases wilh decreasing strain rate without affecting its fatigue life significantly (Fig. 12), In contrast, the A533 Gr B low-alloy steel consists of a bainitic structure, has a relatively high yleld stress. and shows litlle or no intlal hardening and dynamic sirain aging (Fig. 13). At low straln ranges, the A533. Gr B steel shows cycllc softening during the Inltlal 100 cycles of fatigue life (Fig. 14).

The cycllc stress vs. strain curves for $A 106$ Gr $B$ and $A 533$ Gr B steels at $288^{\circ} \mathrm{C}$ are shown in Figs. 15 and 16, respectively; cyclic stress corresponds to the value at half life. The results for A106 or B steel show excellent agreement with the data obtalned by Terrell. ${ }^{*}$ The total strain range $\Delta r_{t}\left(K_{1}\right)$ can be expressed in terms of the cyclic stress range (MPa) with the equation oblatned by Terrell at $288^{\circ} \mathrm{C}$ :

$$
\Delta \varepsilon_{1}=\frac{\Delta \sigma}{1907.8}+\left(\frac{\Delta \sigma}{1010.43}\right) 11.546
$$

The best fit stress us. strain curve for $\mathrm{A533}$ Or B steel is represented by

$$
\Delta c_{1}=\underset{1965.0}{\Delta \sigma}+\left(\begin{array}{c}
\Delta \sigma \\
956.0
\end{array}\right) 111 .
$$

For both steels, an aqueous enviromment has lille or no effect on the cyclic stress-strain behavior. The effect of strain rate on the cyclic stress-strain is quite pronounced in A 106 - Gr B carbon steel because of dymantc strain aging of the materlal, whereas strain rate has a modest effect on the cyclic stress straln curve for A533 Gr B low alloy steel.

In general, the surfaces of A106-Gir B and A533-Gr B specimens tested in simulated PWR water developed a grey/black corrosion scale. In addition. the specimens tested in water containing $0.8 \mathrm{ppm}$ DO showed palches of a loose brown/red deposit. Micrographs 

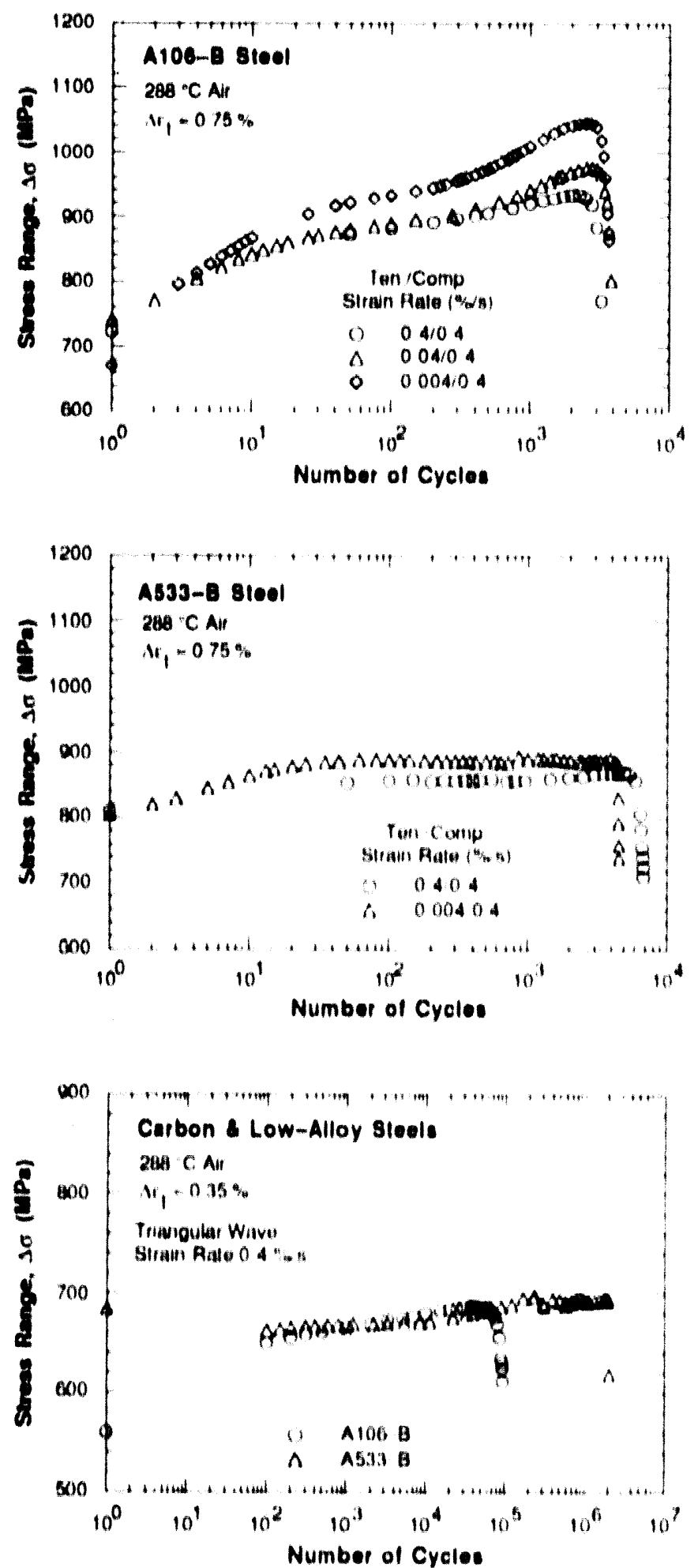

Fyoure 12.

Eiflect of strain rate on cycle sitrain hardening behaver of $A 106$ Gir $B$ sleel in air at $288^{\circ} \mathrm{C}$

rigyure 1:3.

Eiffert of struin rale on chelle strain

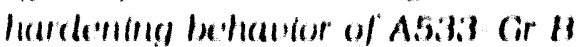

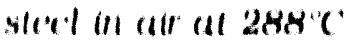

Finurir. 1.1.

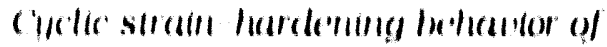
AlOG Gir 11 and Abs.3 Ge 11 sle'els al $0.35 \%$ lotal strain rance and $0.4 \mathrm{k}, \mathrm{s}$ straill rale ill cill

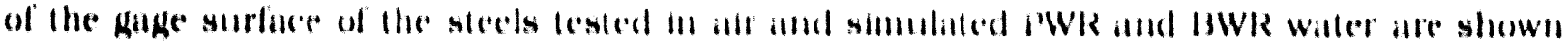

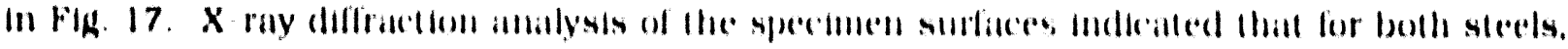
the corrosion scille is primarlly IIIm

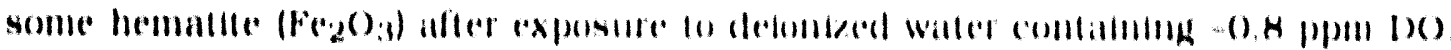



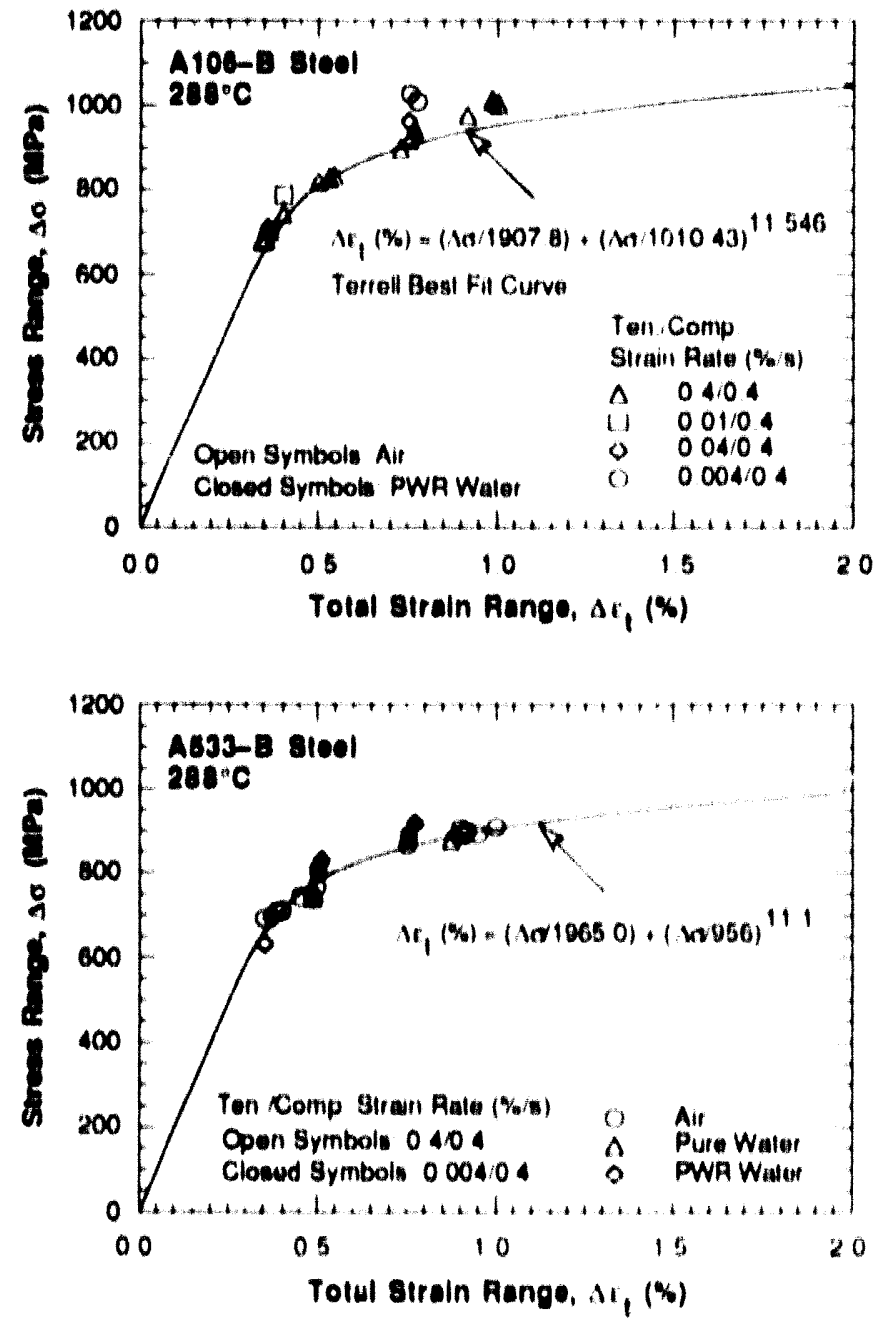

Fyure 15.

Cyclic stress strain curve for A 106 Gir B steel at $288^{\circ} \mathrm{C}$ in air and water environments
Nygure 16.

Cyclic stress strain curve for A.5.33 Gir $B$ steel at $288^{\circ} \mathrm{C}$ in air and uater embironments

All specimens tested in waler showed surfince inlcropllting. Most likely, these surface pits formed by selective dissolution of MuS lincluslons. Typleal examples of microplts on A533 Cr B low alloy steel in slmulalled PWR waler and delonized water containing -0.8 ppm DO are shown in Fig. 18. These plls can act as slles for crack inllatlon: they are often assoclated with cracks. A detulled examinatlon of gage length surfaces of the faligue test specimens is in progress to establish the effect of the aqueous environments on crack Inlliallon.

\subsubsection{Discussion}

Fatigue data in oxygenated waler reveal slgnificant reductions in fatlgue life and a strong dependence on strain rate. However, there is little difference in environmental degradation of fatigue life between A106 Gr B carbon steel and A533-Gr B low-alloy steel that contain comparable sulfur levels. Although the cyclic stress-strain and cyclic hardening behavior is distinctly dilferent. the reduction in fallgule life of the two steels is comparable or somewhat greater for the low alloy steel (Figs. 9 and 10). The carbon steel also exhibils pronounced dymamlc struln agling, whereas strain aging eflects are modest in the low alloy steel. 

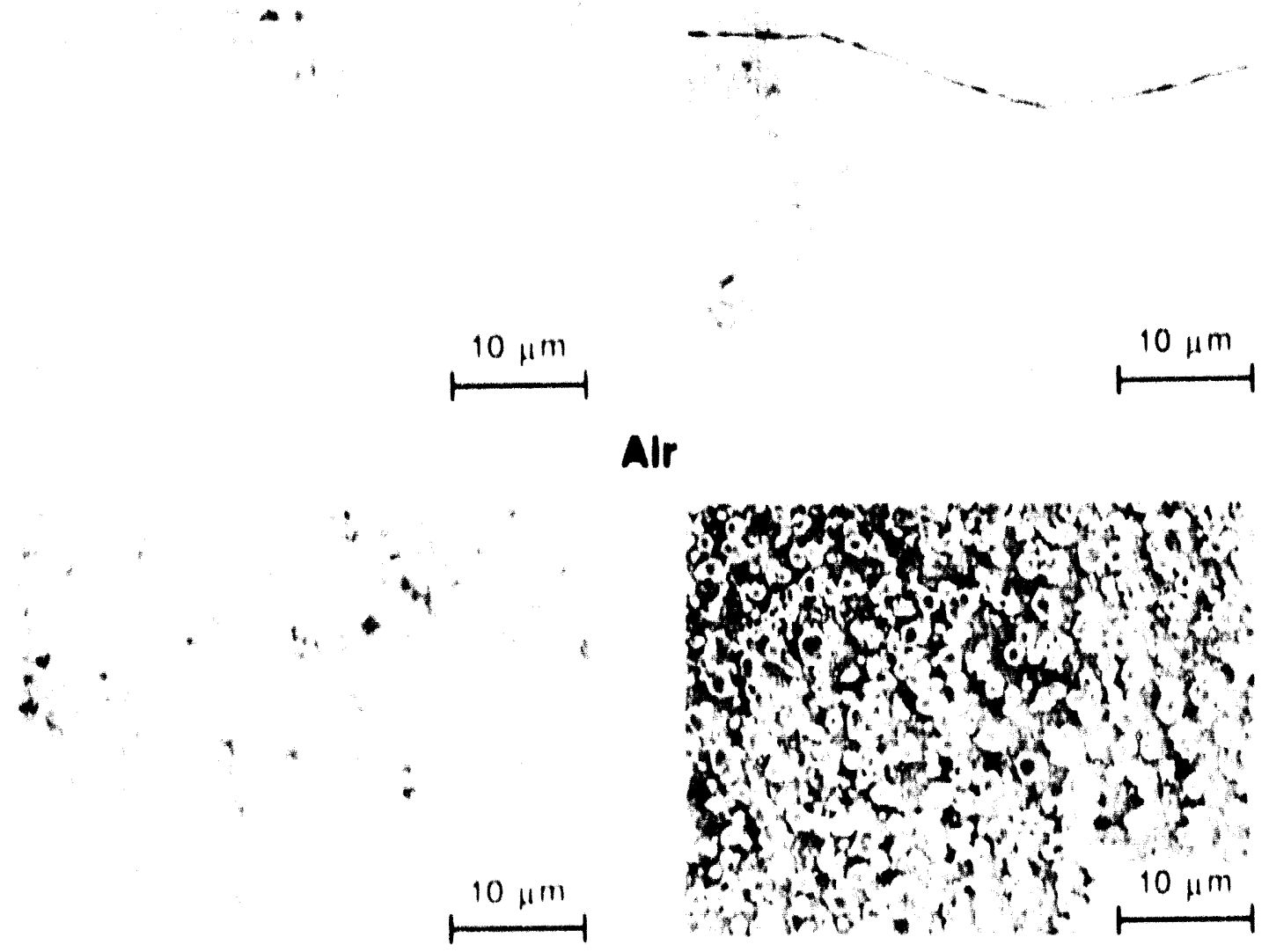

\section{SImulated PWR Wator}

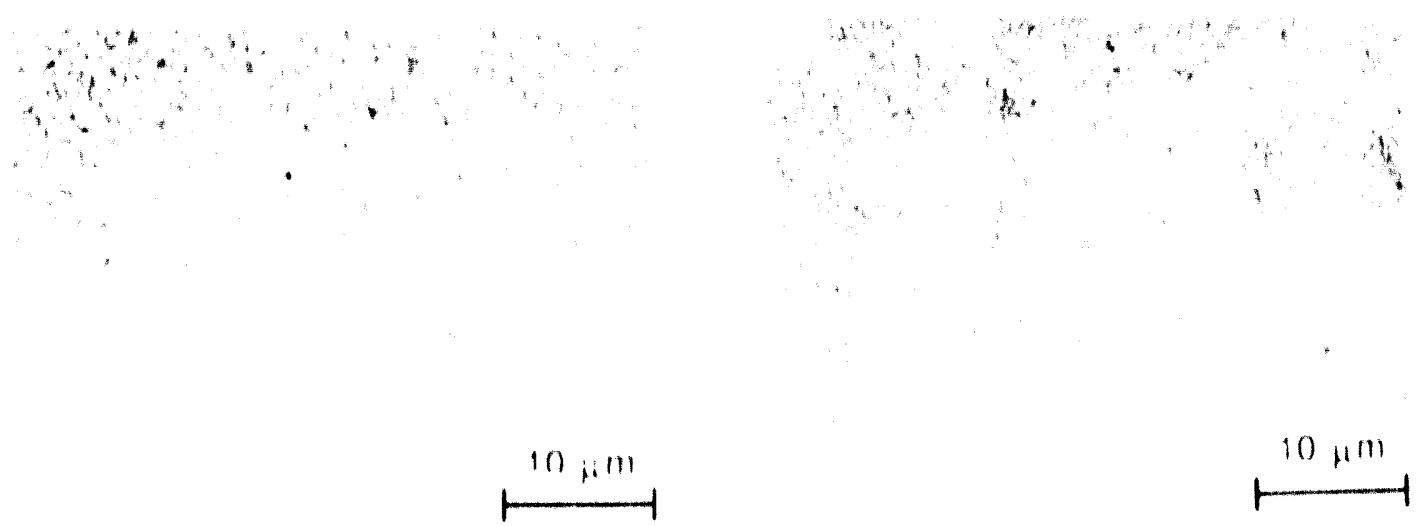

\section{Delonized Water, $0.8 \mathrm{ppm}$ DO}

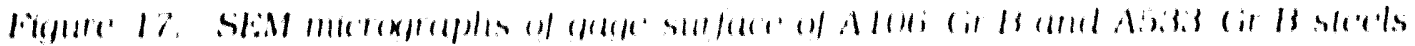

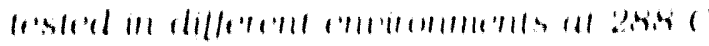

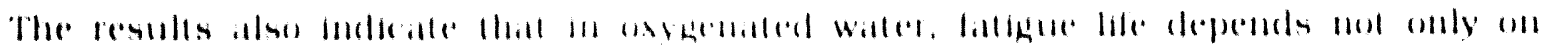

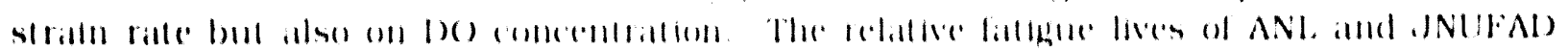

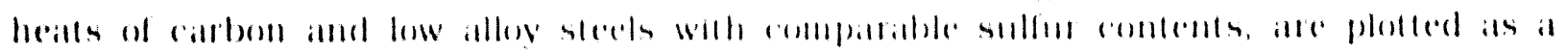




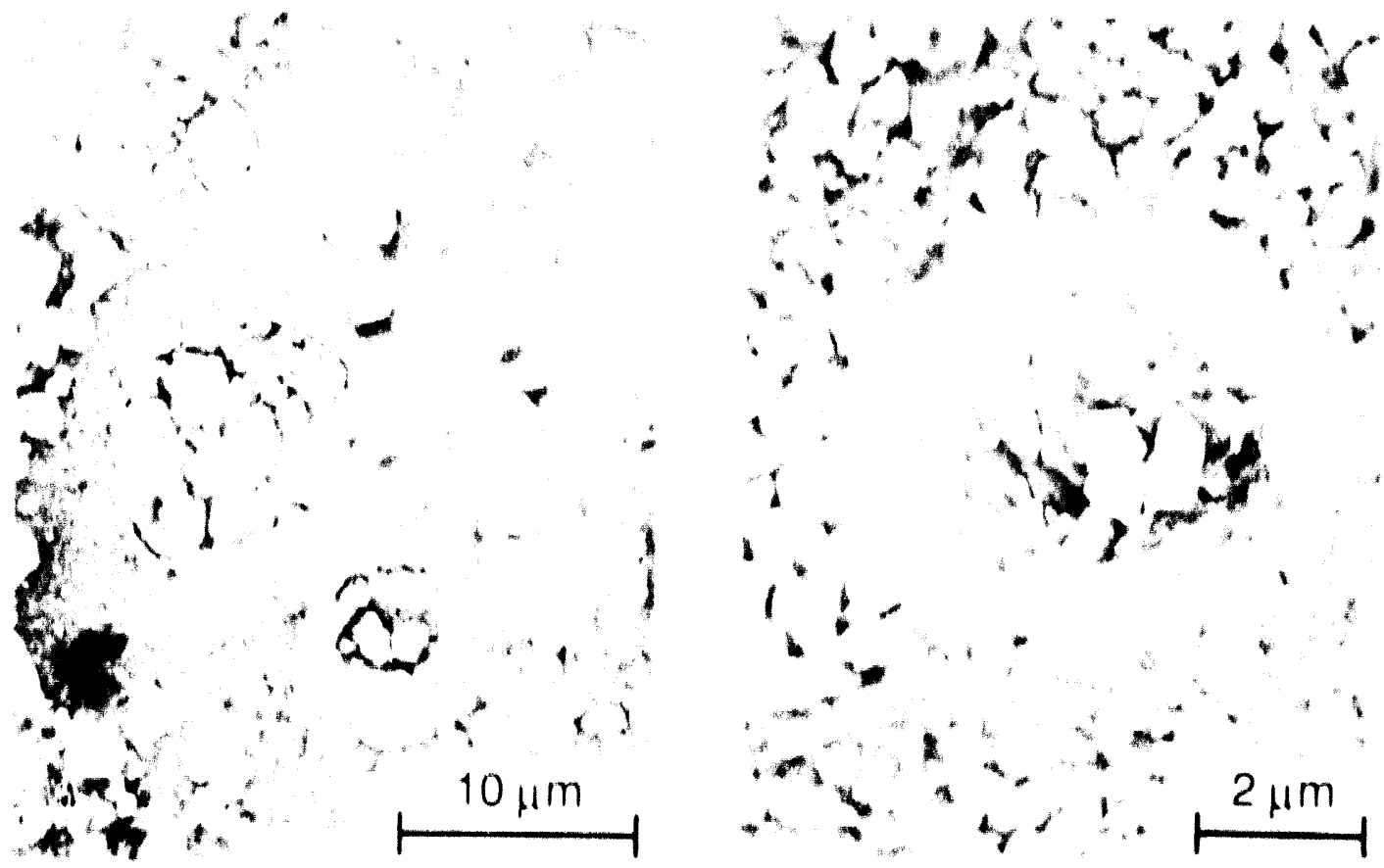

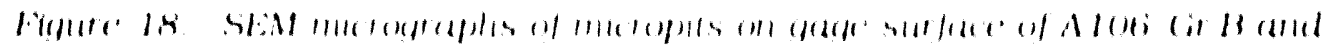

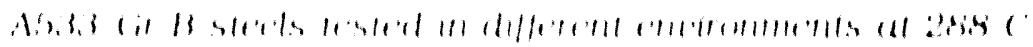

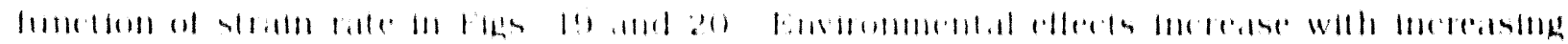

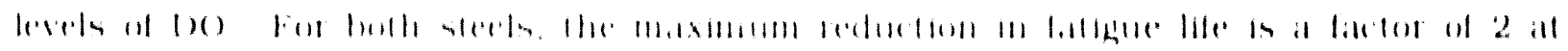

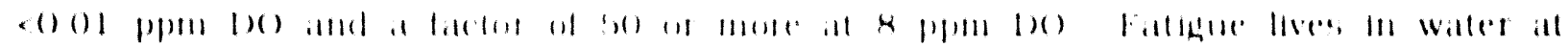

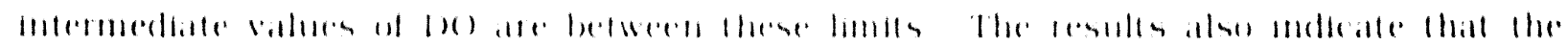

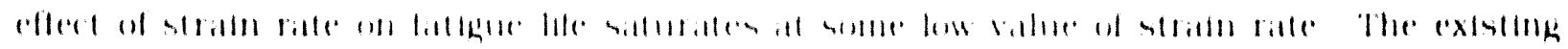

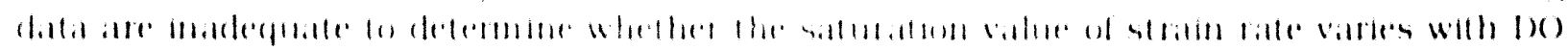

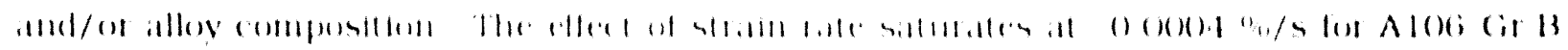

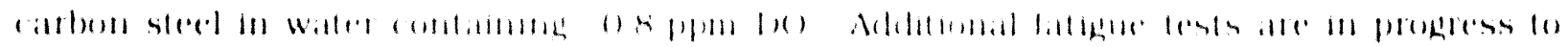

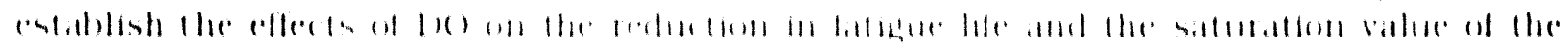
$41,11111,111$.

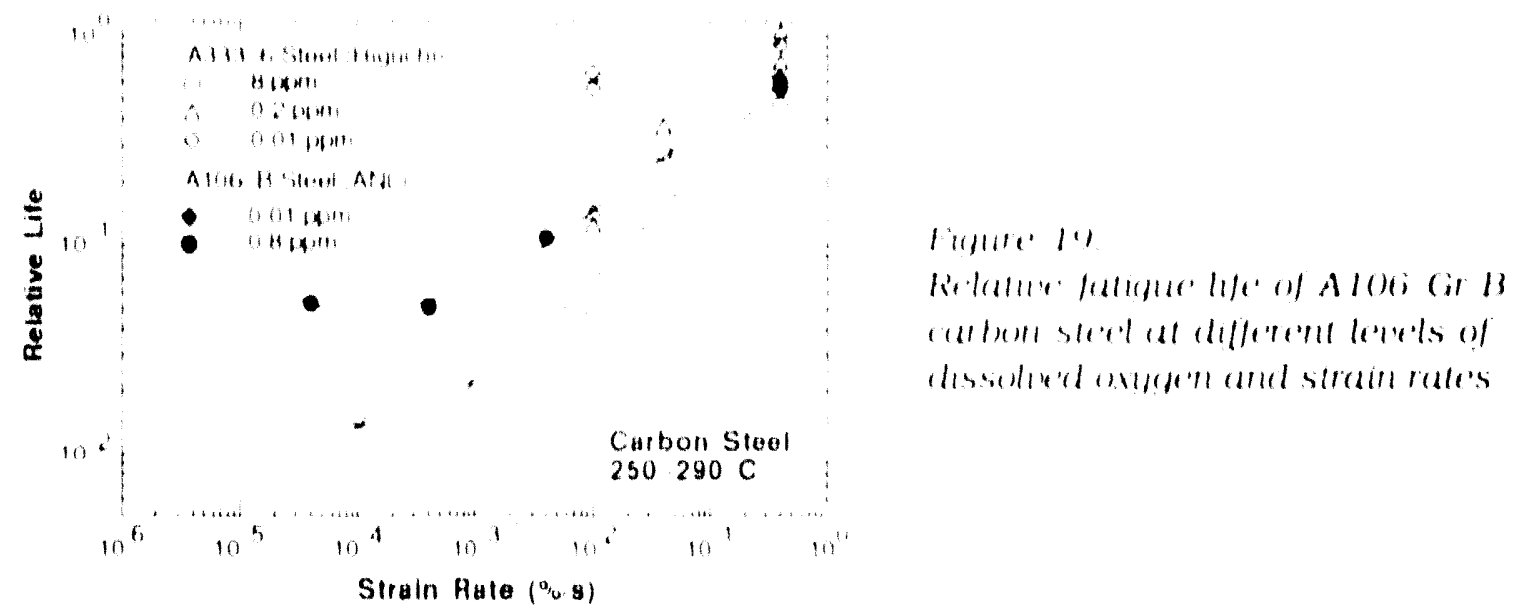




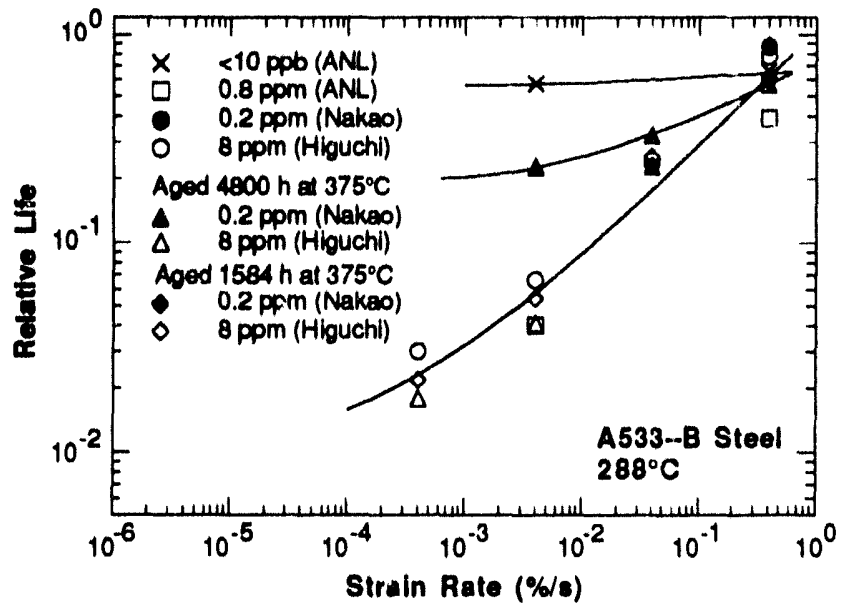

Figure 20.

Relative fatigue life of A533-Gr B low-alloy steel at different levels of dissolved oxygen and strain rates

\section{Environmentally Assisted Cracking of Cast SSs in Simulated BWR Water}

Cast-duplex SSs are used extensively in the nuclear industry in pump casings, valve bodies, piping, and other components in coolant systems of LWRs. The steels correspond to ASTM Specification A-351 grades CF-3, CF-3A, CF-8, CF-8A, and CF-8M, where the compositions of CF-3A and CF-8A fall within the composition limits of CF-3 and CF-8, but are further restricted to obtain ferrite/austenite ratios that result in higher ultimate and yield strengths. The molybdenum-free $\mathrm{CF}-3$ and $\mathrm{CF}-8$ grades contain low- and highcarbon concentrations ( $<0.03$ and $<0.08 \mathrm{wt} \%$, respectively) and are similar in composition to wrought Types $304 \mathrm{~L}$ and $304 \mathrm{SS}$. The Mo-containing CF-3M and CF-8M grades with low- and hign-C content are similar to Types $316 \mathrm{~L}$ and $316 \mathrm{SS}$, respectively. After many years of service at reactor operating temperatures, these steels can undergo thermal aging embrittlement that is caused by precipitation and growth of a $\mathrm{Cr}-\mathrm{rich} \alpha^{\prime}$ phase, an $\mathrm{NL}-$ and Si-rich $G$ phase, $\mathrm{M}_{23} \mathrm{C}_{6}, \gamma$ (austenite) in the ferrite, and additional precipitation and/or growth of existing carbides at the ferrite/austenite phase boundaries. 17-26 These compositional changes increase the tensile strength and decrease the impact energy and fracture toughness of the steels. ${ }^{26-37}$ In general, the low-C CF-3 grade is most resistant and the Mo-bearing high-C CF-8M grade is least resistant to thermal embrittlement.28,31

An inspection of the drywell of a BWR to determine the cause of an increase in unidentified leakage revealed a through-wall crack in the manual gate valve in the condensate return line of the emergency condenser system. Subsequently, the internal components of other valves in the emergency condenser system were removed and inspected by visual, radiographic, and ultrasoric tests. Inspections of the inner surface of the valves revealed cracks near drain holes in the valve bodies, which were made from $\mathrm{CF}$ 8M SS. Some of the cracks were within 0.15-0.35 in. of passing through the 1.25-in. wall thickness $(\approx 70-90 \%$ through wall). A metallographic examination of a boat specimen revealed that the material contained $\approx 15 \%$ delta ferrite and that the crack propagated transgranularly with little secondary cracking, which is characteristic of a fatigue crack.

\footnotetext{
- NRC Information Notice 92-50: Cracking of Valves in the Condensate Return Lines of a BWR Emergency Condenser System, July 2, 1992.
} 
The purpose of the present work is to (a) determine whether local compositional changes and concomitant increases in strength of the materials caused by thermal aging can influence EAC under cyclic loading in high-temperature water, and (b) establish whether CGR curves for wrought SS in high-temperature oxygenated water are applicable to cast grades of the steel in the as-received and thermally aged conditions.

\subsection{Technical Progress (W. E. Ruther, O. K. Chopra, and T. F. Kassner)}

During this reporting period, fracture-mechanics CGR tests were completed on three additional 1TCT specimens of cast SS, namely, as-received CF-8 (Heat 68, No. 681-08) and specimens of CF-8 (Heat 68, No. 682-05) and CF-8M (Heat 75, No. 752-04) aged for $30,000 \mathrm{~h}$ at $350^{\circ} \mathrm{C}$. Results obtained on as-received CF-8M (Heat 75) and specimens of CF$8 \mathrm{M}$ (Heat 75) and $\mathrm{CF}-8$ (Heat 68) steel aged for $10,000 \mathrm{~h}$ at $400^{\circ} \mathrm{C}$ were presented in the previous report. 38 As in the case of the previous specimens, the aging condition was sufficient for both heats of steel to reach a "saturation" Charpy-Impact energy CVsat, 1.e., a minimum value that would be achleved by the materials after very-long-term aging. The actual value of the saturation impact energy for a specific cast SS is independent of aging temperature but depends strongly on the composition of the steel. It is lower for the Mobearing $C F-3 M$ and $C F-8 M$ steels than for the Mo-free $C F-3$ and $C F-8$ steels, and decreases with an increase in ferrite content or the $\mathrm{C}$ or $\mathrm{N}$ concentration in the steels. The room-temperature $C_{V s a t}$ values for cast SSs in thermal aging embrittlement studies conducted at $A L^{35}$ ranged from $\approx 30$ to $162 \mathrm{~J} \cdot \mathrm{cm}^{-2}$. The room-temperature impact energy values for Heats No. $75(\mathrm{CF}-8 \mathrm{M})$ and $68(\mathrm{CF}-8)$ aged for $30,000 \mathrm{~h}$ at $350^{\circ} \mathrm{C}$ were 30 and $65 \mathrm{~J} \cdot \mathrm{cm}^{-2}$, respectively, which are indicative of materials with low fracture toughness after thermal aging. The chemical composition and ferrite content of these steels, and of CF-3 and $-3 \mathrm{M}$ grades tested previously, ${ }^{39,40}$ are given in Table 5.

Table 5. Chemical composition and ferrite content of cast SSs for corrosion fatigue tests in simulated BWR water

\begin{tabular}{|c|c|c|c|c|c|c|c|c|c|c|c|c|}
\hline \multirow[t]{2}{*}{ Material } & \multirow{2}{*}{$\begin{array}{l}\text { Heat } \\
\text { No. }\end{array}$} & \multicolumn{9}{|c|}{ Composition (wt.\%) } & \multicolumn{2}{|c|}{ Ferrite (\%) } \\
\hline & & $\mathrm{Cr}$ & Mo & $\mathrm{Ni}$ & $\mathrm{Mn}$ & Si & C & $N$ & $\mathrm{P}$ & $\mathrm{s}$ & Calc. & Meas. \\
\hline $\mathrm{CF}-8$ & 68 & 20.64 & 0.31 & 8.08 & 0.64 & 1.07 & 0.063 & 0.062 & 0.021 & 0.014 & 14.9 & 23.4 \\
\hline $\mathrm{CF}-8 \mathrm{M}$ & 75 & 20.86 & 2.58 & 9.12 & 0.53 & 0.67 & 0.065 & 0.052 & 0.022 & 0.012 & 24.8 & 27.8 \\
\hline $\mathrm{CF}-3$ & $\mathrm{P} 2$ & 20.20 & 0.16 & 9.38 & 0.74 & 0.94 & 0.019 & 0.062 & 0.019 & 0.006 & 12.5 & 15.6 \\
\hline CF-3M & F5524 & 19.38 & 2.38 & 11.80 & 0.96 & 1.35 & 0.018 & 0.099 & 0.015 & 0.005 & 5.9 & 5.0 \\
\hline
\end{tabular}

CGRs of the as-recelved CF- 8 and aged $\left(30,000 \mathrm{~h}\right.$ at $\left.350^{\circ} \mathrm{C}\right) \mathrm{CF}-8$ and $\mathrm{CF}-8 \mathrm{M}$ specimens are shown in Table 6. Four tests were conducted in $289^{\circ} \mathrm{C}$ high-purity (HP) water containing 4-5 ppm DO at a frequency of $0.08 \mathrm{~Hz}$, and stress intensities $\mathrm{K}_{\max }$ of 30 to $35 \mathrm{MPa} \cdot \mathrm{m}^{1 / 2}$ where the load ratlo, $R$, was varled from 0.3 to 0.9 . The oxygen level was then reduced by a factor of 10 (to $=0.4-0.5 \mathrm{ppm}$ ) and several of the tests were repeated. After Test 7, the system was shut down to remove the aged CF-8M specimen that had reached the maximum permissible crack length and the experiment is being continued to investigate the effects of DO concentration on the CGRs of the remaining CF- 8 specimens. 


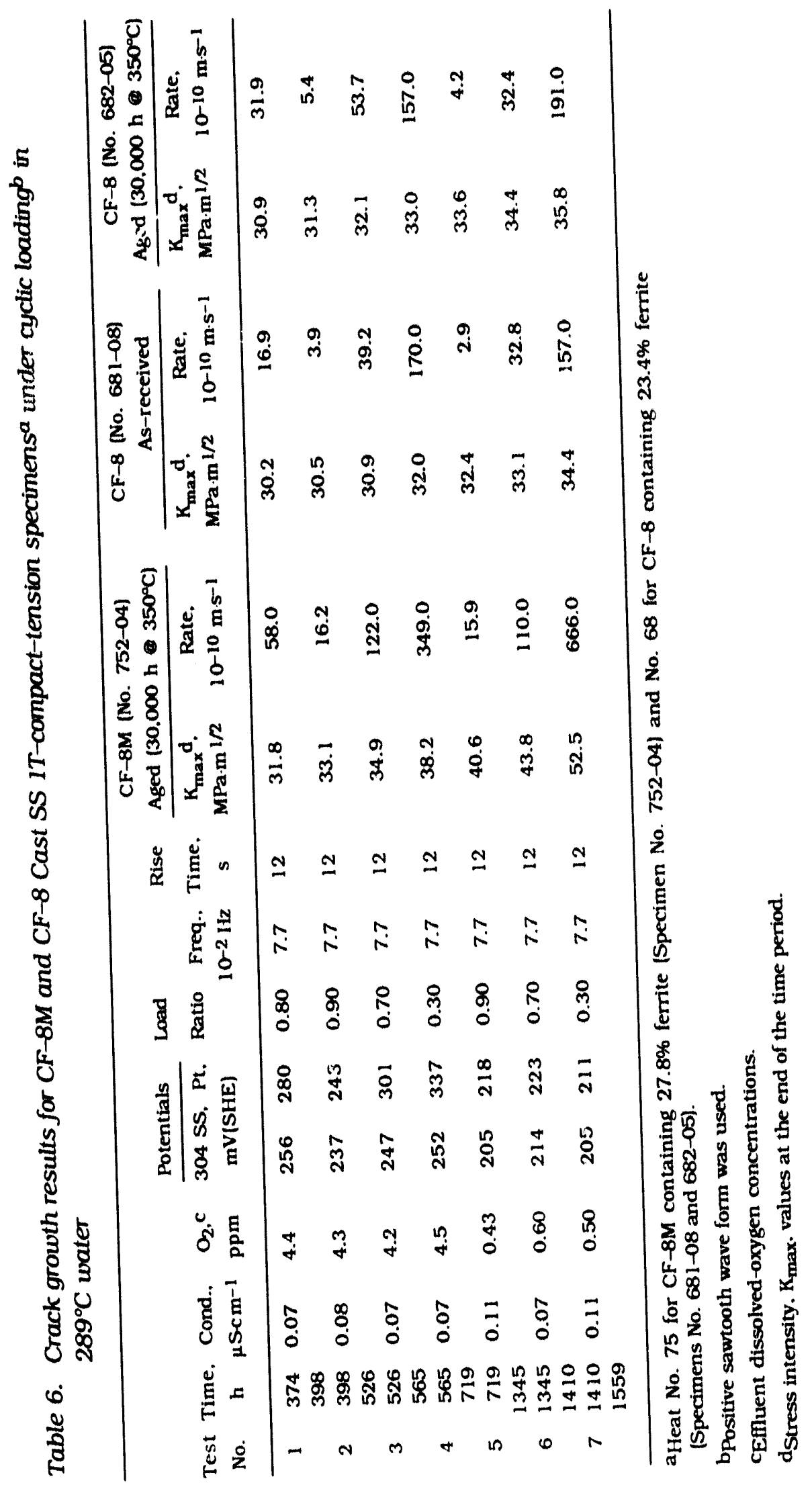


Figure 21 shows the dependence of the CGRs of as-recelved and aged CF-8M and CF- 8 specimens on DO concentration in HP water from these and previous tests 38 at $R$ values of 0.90-0.95. At DO concentrations $>1 \mathrm{ppm}$, the CGRs of thermally aged CF-8M are higher by one order of magnitude than for the steel in the as-recelved condition. Thermal aging has a smaller effect on the CGRs of CF-8 SS under these conditions.

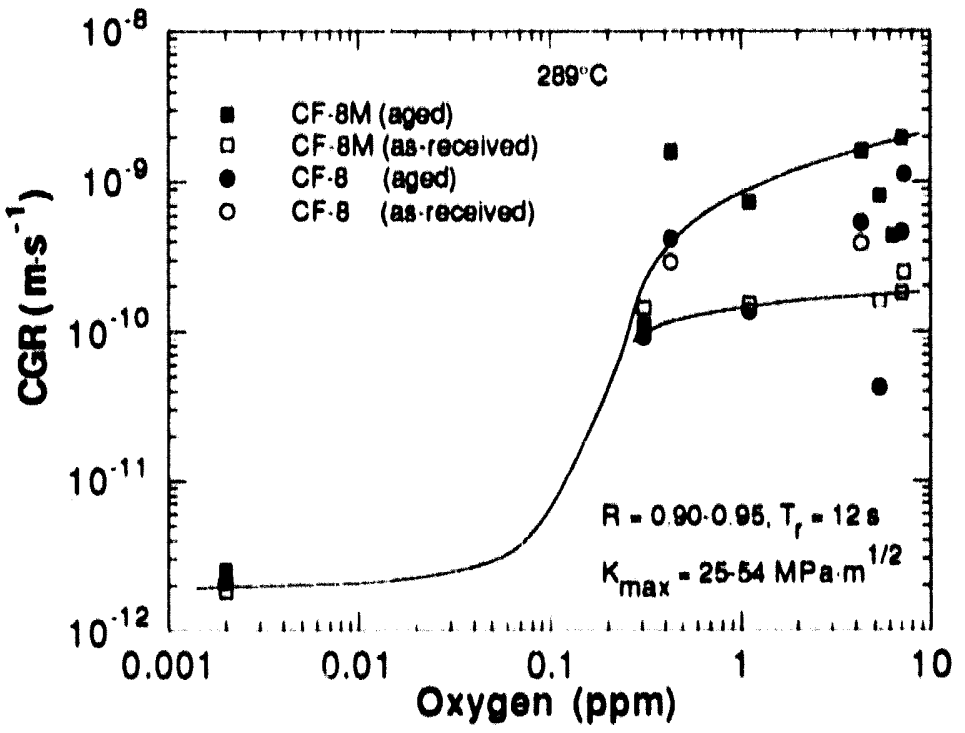

Fygure 21. Crack growth rates of as-recelved and thermally aged $C F-8 M$ and $C F-8$ grades of cast SS under high-R loading in $\mathrm{HP}$ water at $289^{\circ} \mathrm{C}$

The experimental results in Table 7 for these specimens and for as-recelved CF-3 and CF-3M specimens reported previously 39.40 were compared with predicted CGRs for wrought SSs in air and in water under the various loading conditions (Fig. 22). The lines denoted as $a_{\text {super }} 8.0$ and $a_{\text {super }} 0.2$ in Fig. 22 represent predictions from interim correlathons developed a Argonne for $289^{\circ} \mathrm{C}$ water that contains -8 and $=0.2 \mathrm{ppm} D 0.41$ The predictions of the present correlation for wrought SS in air in Section XI of the ASME code are represented by the dlagonal stralght lines. Clearly, the alr curve is frequently nonconservative. The experimental CGRs for CF-8, $-8 \mathrm{M}$, and $-3 \mathrm{M}$ specimens lie above the air line (solld curve), but for the most part are bounded by CGRs from the modified correlations for wrought SSs in water at $289^{\circ} \mathrm{C}$. The CGRs of the CF-3M and CF-8M specimens (with carbon content of 0.018 and 0.065 wt.\% and ferrite content of -5 and $27.8 \%$, respectively) show the largest environmental enhancement in both the as-recelved and aged conditions. 
Table 7. Summary of crack growth results for cast SS spectmens a at different load ratiob and stress intenstly values in $289^{\circ} \mathrm{C}$ water

\begin{tabular}{|c|c|c|c|c|c|c|c|c|c|c|}
\hline \multicolumn{3}{|c|}{ Water Chemistry } & Potentials & \multirow{2}{*}{$\begin{array}{l}\text { Load } \\
\text { Ratles }\end{array}$} & \multirow[b]{2}{*}{$\begin{array}{l}\text { Freq. } \\
10^{-2} \mathrm{~Hz}\end{array}$} & \multirow{2}{*}{$\begin{array}{l}\text { Rise: } \\
\text { Time, } \\
\end{array}$} & \multicolumn{3}{|c|}{ COK Data } & \multirow{2}{*}{$\begin{array}{c}\text { ANI. } \\
\text { Report } \\
\text { No. }\end{array}$} \\
\hline $\begin{array}{l}\text { Cond., } \\
\mu s \mathrm{~cm}^{-1}\end{array}$ & $\begin{array}{l}\mathrm{O}_{2} \\
\mathrm{ppm}\end{array}$ & $\begin{array}{l}s 0^{2} \\
\mathrm{ppb}\end{array}$ & $\begin{array}{l}304 \mathrm{ss}, \quad P t \\
m \vee(\mathrm{S} \| \mathrm{E})\end{array}$ & & & & $\begin{array}{l}K_{\max }{ }^{c} \\
\text { MIam } m^{1 / 2}\end{array}$ & $\Delta K, d$ & $\begin{array}{c}\text { Rute. } \\
10-10 \mathrm{~m} \cdot-1\end{array}$ & \\
\hline
\end{tabular}

\begin{tabular}{|c|c|c|c|c|c|c|c|c|c|c|c|}
\hline \multirow[b]{2}{*}{0.90} & \multirow[b]{2}{*}{0.2} & \multirow[b]{2}{*}{100} & \multicolumn{9}{|c|}{ As-recelved CF-3M Specimen (lleat No. F5524) Containing 5.0\% Ferrite } \\
\hline & & & 136 & 120 & 0.95 & 7.7 & 12 & 22.0 & 1.13 & 1.90 & $90 / 4$ \\
\hline 0.90 & 0.2 & 100 & 108 & 66 & $0.25 \mathrm{e}$ & 10.0 & 5 & 20.7 & 18.50 & 38.0 & $90 / 4$ \\
\hline 0.90 & 0.2 & 100 & 81 & 41 & $0.9 B$ & 7.7 & 12 & 24.0 & 1.20 & 2.50 & $90 / 4$ \\
\hline \multirow[t]{2}{*}{1.10} & 0.2 & 100 & 134 & 95 & 1.00 & 0 & $\infty$ & 24.1 & 0 & 0.32 & $90 / 4$ \\
\hline & & \multicolumn{10}{|c|}{ As-recelved $\mathrm{CF}$ 3 Specinen (Ileal No. 12 ) Containing 15.6\%, Ferrite } \\
\hline 0.93 & 0.2 & 100 & 150 & 208 & 0.50 & 7.7 & 12 & 19.6 & 9.80 & 27.0 & $90 / 48$ \\
\hline 0.92 & 0.2 & 100 & 147 & 200 & 0.90 & 7.7 & 12 & 19.7 & 1.97 & 0.09 & $90 / 48$ \\
\hline 0.92 & 0.2 & 100 & 121 & 159 & 0.90 & 7.7 & 12 & 21.8 & 2.18 & 0.40 & $90 / 48$ \\
\hline \multirow[t]{2}{*}{0.92} & 0.2 & 100 & 176 & 210 & 0.95 & 7.7 & 12 & 29.2 & 1.46 & 0.11 & $90 / 48$ \\
\hline & \multicolumn{11}{|c|}{ Ar-recolved CF-8M Specinnen (Ileat No. 75) Containlng $27.8 \%$ Ferrite } \\
\hline 0.13 & 6.2 & 0 & 258 & 332 & 0.95 & 7.7 & 12 & 25.3 & 1.20 & $<0.02$ & $9.3 / 2$ \\
\hline 0.16 & 6.3 & 0 & 240 & 317 & 0.95 & 7.7 & 12 & 34.7 & 1.7 .3 & 1.6 & $93 / 2$ \\
\hline 0.14 & 7.0 & 0 & 242 & 296 & 0.95 & 7.7 & 12 & 35.2 & 1.76 & 1.8 & $93 / 2$ \\
\hline 0.13 & $<0.002$ & 0 & -580 & -580 & 0.95 & 7.7 & 12 & 35.2 & 1.76 & $<0.02$ & $9: 3 / 2$ \\
\hline 0.18 & 0.3 & 0 & 198 & 243 & 0.95 & 7.7 & 12 & 36.4 & 1.82 & 1.4 & $9.3 / 2$ \\
\hline 0.11 & 1.1 & 0 & 216 & 260 & 0.98 & 7.7 & 12 & 36.8 & 1.84 & 1.5 & $9: 3 / 2$ \\
\hline 0.11 & 0.9 & 0 & 206 & 257 & 1.0 & 0 & - & 36.8 & 0 & $<0.02$ & $\theta 3 / 2$ \\
\hline \multirow[t]{2}{*}{0.10} & 7.2 & 0 & 247 & 301 & 0.95 & 7.7 & 12 & 45.0 & 2.28 & 2.5 & $93 / 2$ \\
\hline & \multicolumn{11}{|c|}{ 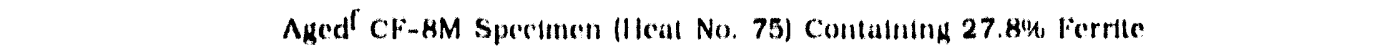 } \\
\hline 0.13 & 6.2 & 0 & 258 & 332 & 0.95 & 7.7 & 12 & 24.7 & 1.23 & 4.4 & $9: 3 / 2$ \\
\hline 0.16 & 5.3 & $\mathbf{0}$ & 240 & 317 & 0.45 & 7.7 & 12 & 37.2 & 1.86 & 8.1 & $93 / 2$ \\
\hline 0.14 & 7.0 & 0 & 242 & 296 & 0.95 & 7.7 & 12 & 46.0 & 2.30 & 19.8 & $93 / 2$ \\
\hline 0.13 & $<0.002$ & 0 & -560 & -580 & 0.95 & 7.7 & 12 & 46.0 & 2.30 & $<0.02$ & $93 / 2$ \\
\hline 0.18 & 0.3 & 0 & 198 & 243 & 0.95 & 7.7 & 12 & 47.5 & 2.38 & 1.1 & $9: 3 / 2$ \\
\hline 0.11 & 1.1 & 0 & 216 & 260 & 0.45 & 7.7 & 12 & 533.6 & 2.68 & 7.3 & $93 / 2$ \\
\hline 0.11 & 0.9 & 0 & 206 & 257 & 1.0 & 0 & - & 61.4 & 0 & 20.8 & $9.3 / 2$ \\
\hline
\end{tabular}

Agedk CF-AM Specimen (lledal No, 75) Contalning 27, kw, Ferrile:

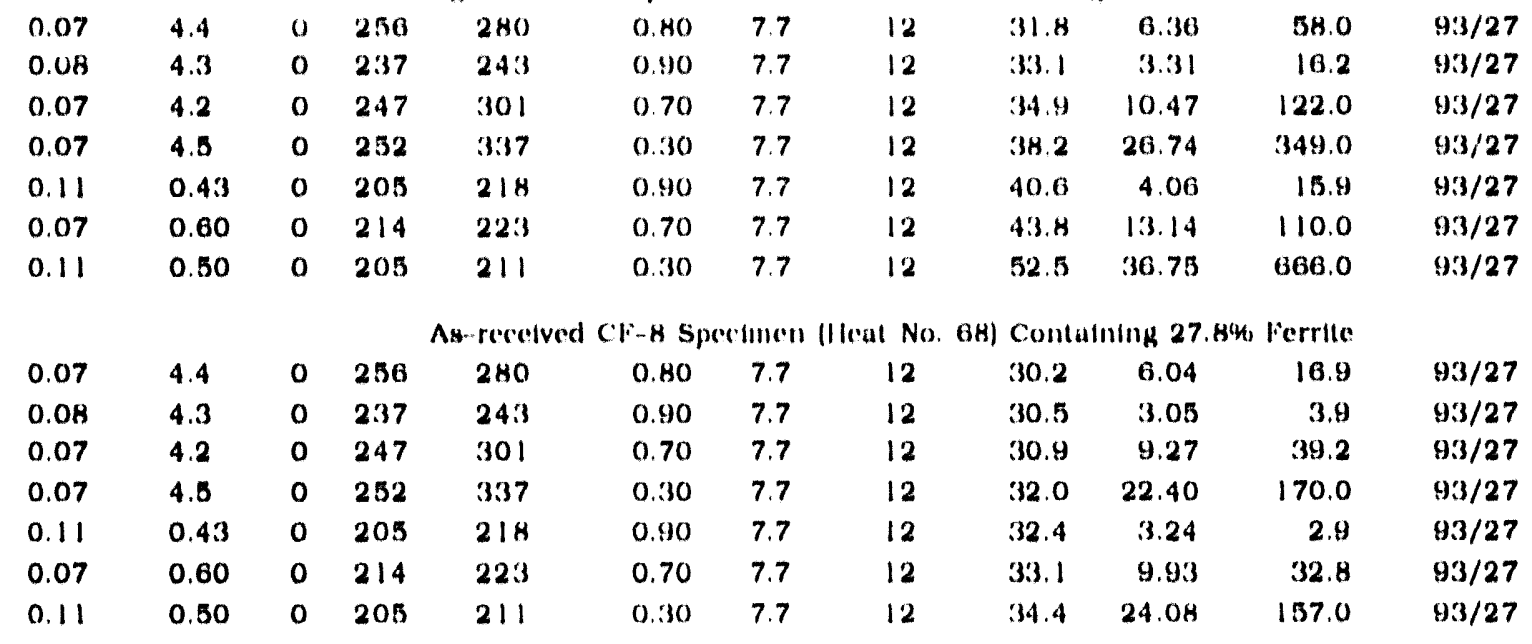


Table 7. (Cont'd)

\begin{tabular}{|c|c|c|c|c|c|c|c|c|c|c|c|}
\hline \multicolumn{3}{|c|}{ Water Chemistry } & \multicolumn{2}{|c|}{ Potentials } & \multirow{2}{*}{$\begin{array}{l}\text { loud } \\
\text { Ratio }\end{array}$} & \multirow[b]{2}{*}{$\begin{array}{l}\text { Freq. } \\
10^{-2} 11 \%\end{array}$} & \multirow{2}{*}{$\begin{array}{l}\text { Rise } \\
\text { Time. } \\
\text { s }\end{array}$} & \multicolumn{3}{|c|}{ COR Data } & \multirow{2}{*}{$\begin{array}{c}\text { ANL } \\
\text { Report } \\
\text { No. }\end{array}$} \\
\hline $\begin{array}{l}\text { Cond., } \\
\mu S \mathrm{~cm}^{-1}\end{array}$ & $\begin{array}{l}\mathrm{O}_{2} \\
\text { ppin }\end{array}$ & $\begin{array}{l}\mathrm{so} 3 \\
\mathrm{ppb}\end{array}$ & $\begin{array}{l}304 \text { ss } \\
\text { InVIs }\end{array}$ & $\begin{array}{l}\text { PI. } \\
\text { |IE) }\end{array}$ & & & & $\begin{array}{l}K_{\max }{ }^{c} . \\
\text { MPain } 1 / 2\end{array}$ & $\Delta K{ }^{d}$ & $\begin{array}{c}\text { Rale. } \\
10^{-10} \mathrm{~m} \cdot \mathrm{s}^{-1}\end{array}$ & \\
\hline & \multicolumn{11}{|c|}{ Aged CF-8 Specimen (lleal No, 68) Contalning $27.8 \%$ Ferrite } \\
\hline 0.13 & 6.2 & 0 & 258 & 332 & 0.95 & 7.7 & 12 & 26.0 & 1.30 & $<0.02$ & $9: 3 / 2$ \\
\hline 0.16 & 5.3 & 0 & 240 & 317 & 0.95 & 7.7 & 12 & 35.0 & 1.75 & 0.42 & $93 / 2$ \\
\hline 0.14 & 7.0 & 0 & 242 & 296 & 0.45 & 7.7 & 12 & 38.9 & 1.85 & 4.6 & $93 / 2$ \\
\hline 0.13 & $<0.002$ & 0 & -560 & -580 & 0.45 & 7.7 & 12 & 38.9 & 1.85 & $<0.02$ & $93 / 2$ \\
\hline 0.18 & 0.3 & 0 & 198 & 243 & 0.45 & 7.7 & 12 & 37.4 & 1.87 & 0.93 & $93 / 2$ \\
\hline 0.11 & 1.1 & 0 & 216 & 260 & 0.95 & 7.7 & 12 & 37.8 & 1.89 & 1.4 & $93 / 2$ \\
\hline 0.11 & 0.9 & 0 & 206 & 257 & 1.0 & 0 & $\infty$ & 37.8 & 0 & $<0.02$ & $\theta 3 / 2$ \\
\hline \multirow[t]{2}{*}{0.10} & 7.2 & 0 & 247 & 301 & 0.98 & 7.7 & 12 & 52.6 & 2.62 & 11.3 & $93 / 2$ \\
\hline & \multicolumn{11}{|c|}{ AdedK CF-H Specimen (llout No. 68) Contalning $27.8 \%$ Ferrite } \\
\hline 0.07 & 4.4 & 0 & 256 & 280 & 0.80 & 7.7 & 12 & 30.9 & 6.18 & 31.9 & $93 / 27$ \\
\hline $0.0 \mathrm{~B}$ & 4.3 & 0 & 237 & $24: 3$ & 0.40 & 7.7 & 12 & 31.3 & 3.13 & 5.4 & $9: 3 / 27$ \\
\hline 0.07 & 4.2 & 0 & 247 & 301 & 0.70 & 7.7 & 12 & $\$ 2.1$ & 9.63 & 5.3 .7 & $93 / 27$ \\
\hline 0.07 & 4.5 & 0 & 252 & 337 & 0.30 & 7.7 & 12 & 333.0 & 23.10 & 157.0 & $93 / 27$ \\
\hline 0.11 & 0.43 & 0 & 205 & 218 & 0.40 & 7.7 & 12 & 33.6 & 3.36 & 4.2 & $93 / 27$ \\
\hline 0.07 & 0.60 & 0 & 214 & $22: 3$ & 0.70 & 7.7 & 12 & 34.4 & 10.32 & 32.4 & $93 / 27$ \\
\hline 0.11 & 0.50 & 0 & 205 & 211 & 0.30 & 7.7 & 12 & 33.8 & 25.06 & 191.0 & $93 / 27$ \\
\hline
\end{tabular}

"Compact-tension specimens were fabricaled from lleat No, F5524 (0.7ICl') and from Heats No. 12, 68. and 75 (ITCT).

bposltive sawtoxth waveform was used.

estress intensity. Kinax, value at the end of each time period.

$d_{\Delta K}=K_{\max }(1-R)$, where the lond mitlo $R=K_{m m ! n} / K_{\max }$.

esine waveform was used.

'Spectmens aged for $10,000 \mathrm{~h}$ at $400^{\circ} \mathrm{C}$.

Rspecimens aged for $30,000 \mathrm{~h}$ at 350 " $\mathrm{C}$.

As mentioned previously, thermal aging embrittement is caused by precipltation and growth of a $\mathrm{Cr}$-rich $\alpha^{\prime}$ phase, a $\mathrm{NI}$ - and SI-rich $\mathrm{G}$ phase, $\mathrm{M}_{23} \mathrm{C}_{6}$. $\gamma$ (alustenite) in the ferrite. and additional precipitation and/or growth of existing carbides at the ferrite/austenite phase boundarles. These composillonal changes increase the tenslle strength and decrease the impact energy and fracture loughness of the steels, where, in general, the Mo-free grades (CF-3 and - 8 ) are more resistant and the Mo-bearing (CF-3M and -8M) grades are less resistant to thermal embrittlement. The tenslle propertles 35 of the varlous steels in the as-received and thermally aged conditions at $289^{\circ} \mathrm{C}$ are shown in Table 8 . Tensile properties of wrought Types $304^{42}$ and $316 N^{43}$ SS are also included in the table. To determine whether corrosion-faligue behavior of the steels in high-temperature water can be correlated with the thermal aging characteristlcs, the CGRs under high-R loading were plotted versus the square of yleld stress $\sigma_{y}$ for specimens of the same heats under identical aging conditions (time and temperature). The limited results in Fig. 23 indicate a linear relationship between the CGRs and $\sigma_{y}{ }^{2}$ in water containing 4-8 and 0.2-0.4 ppm DO, within the uncertainty of the experimental data. Data for wrought grades of Types 304 and 316NG SS are also tricluded in the ligures (solld symbols). 44 

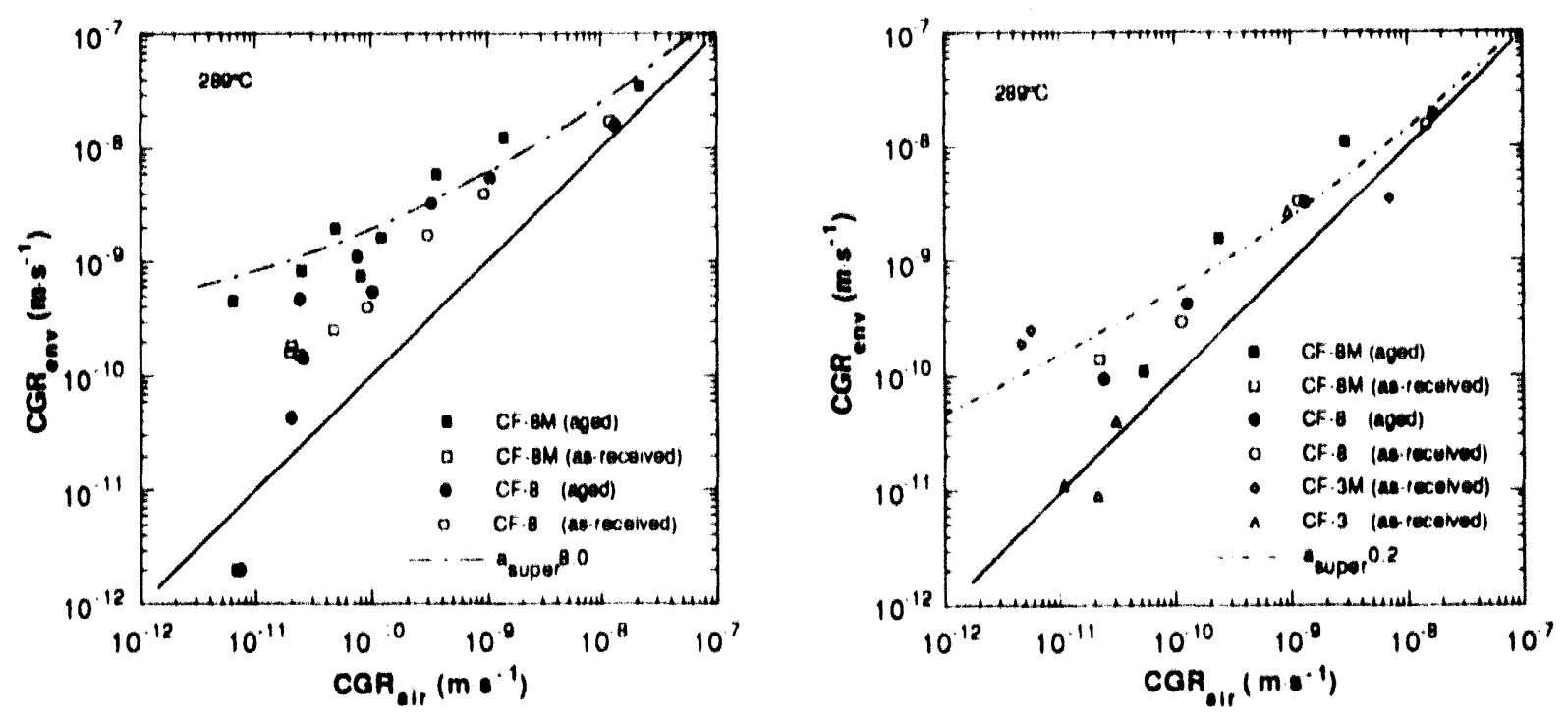

Fyure 22. Corrosion fatlgue data for as recelled CF-3, $-3 M$, and $8 M$ and aged $C F-8 M$ and 8 cast SS in water containting 8 (leju and 0.2 (right) ppm DO at $289^{\circ} \mathrm{C}$. Diagonal lines correspond to crack growth in air in Section XI of the ASME Code. Dashed lines indicate predictions from a correlation for wrought SS. 41

Table 8. Tensile propertles of urought and cast SSs at $289^{\circ} \mathrm{C}$

\begin{tabular}{|c|c|c|c|c|c|c|c|c|c|}
\hline \multirow[t]{2}{*}{ Malerial } & \multirow[t]{2}{*}{ Heat No. } & \multicolumn{2}{|c|}{ Aglng Condillons } & \multicolumn{5}{|c|}{ Tellslle Propertles } & \multirow[t]{2}{*}{ Rel. No. } \\
\hline & & $\begin{array}{l}\text { Time } \\
\text { (h) }\end{array}$ & $\begin{array}{c}\text { Temp. } \\
\left.\text { ( }{ }^{\circ} \mathrm{Cl}\right)\end{array}$ & $\begin{array}{c}\sigma_{11} \\
\left(\mathrm{MP}^{\prime} \mathrm{a}\right)\end{array}$ & $\begin{array}{c}\sigma_{y} \\
\left(M P^{\prime}(1)\right.\end{array}$ & $\begin{array}{l}l_{1} \\
(16 / 1)\end{array}$ & $\begin{array}{l}R A^{\prime \prime} \\
\left.(1)_{1}\right)\end{array}$ & $\begin{array}{c}H^{b} \\
\left(M P^{\prime} a\right)\end{array}$ & \\
\hline 304 SS & 30956 & \multicolumn{2}{|c|}{ Solullon-Annenled } & 512.0 & 152.0 & 53.0 & 77.0 & 679.2 & 42 \\
\hline$C F 8$ & 68 & \multicolumn{2}{|c|}{ As Recelved } & 412.3 & 156.1 & 37.9 & 60.6 & 675.1 & 35 \\
\hline$C F-8$ & 68 & 10.000 & 400 & 475.6 & 176.7 & 34.4 & 47.6 & 868.9 & 35 \\
\hline $\mathrm{CF}-8$ & 68 & 30.000 & 350 & 427.3 & 190.4 & 25.3 & 41.7 & $9: 36.4$ & 35 \\
\hline $316 \mathrm{NG}$ & $\mathrm{P9} 1576$ & \multicolumn{2}{|c|}{ Solution Anmealed } & 466.0 & 142.0 & 29.0 & 64.0 & 1117.2 & 43 \\
\hline$C F-8 M$ & 75 & \multicolumn{2}{|c|}{ As Recelved } & 174.8 & 191.5 & 30.5 & 45.0 & 928.9 & 35 \\
\hline $\mathrm{CF}-8 \mathrm{M}$ & 75 & 10,000 & 400 & 6330.4 & 208.2 & 23.7 & 31.4 & 1781.4 & 35 \\
\hline$C F \sim 8 M$ & 75 & 30.000 & 350 & 615.9 & 264.4 & 23.0 & 30.2 & 1528.3 & 35 \\
\hline
\end{tabular}

MReduction in area.

bstrain-hardening coc fliclent: $\|=\left|\sigma_{U}-\sigma_{y}\right| / t_{\tau}$. 

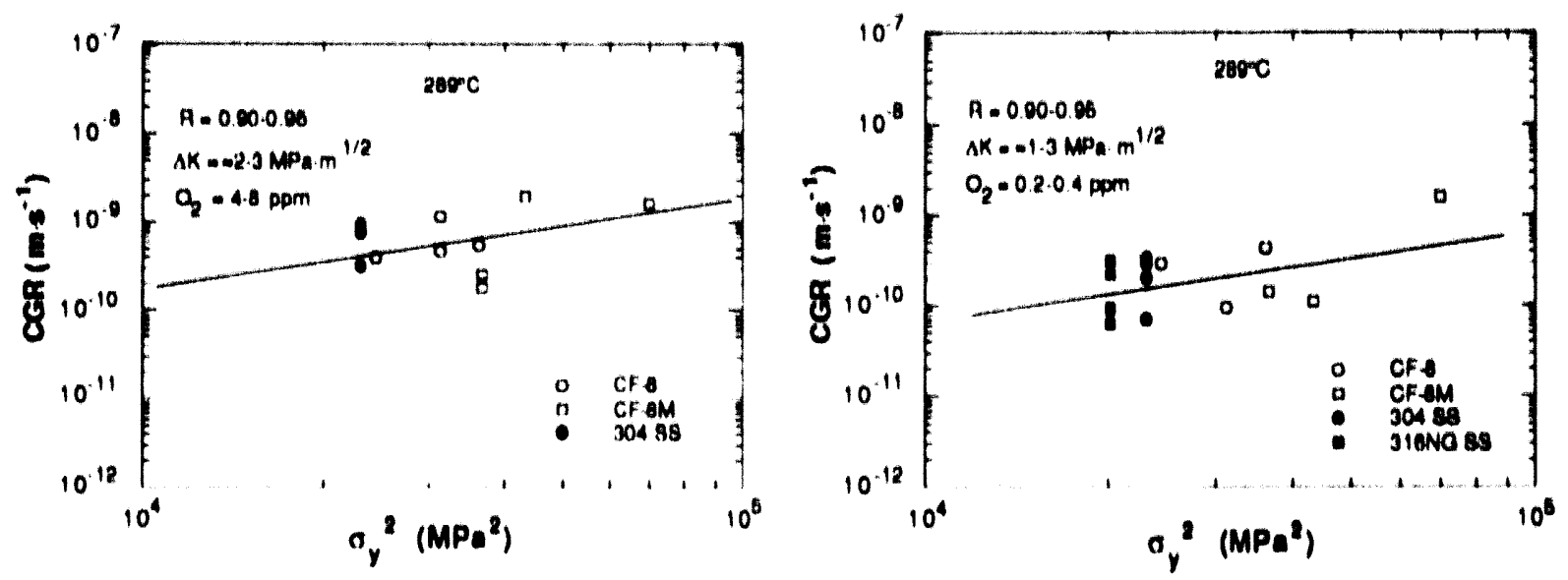

Figure 23. Dependence of CORs of as-recelved and thermally aged CF-8 and $-8 M$ cast SS on yteld stress of the materials at $289^{\circ} \mathrm{C}$ under high-R loading in water containing 4-8 (lefU and 0.2-0.4 (right) ppm DO. Solid symbols denote wrought Types 304 and 316 NG SS.

In the case of pure mechanical fatigue, where environmental effects are absent, the CGR da/dN (m/cycle) can be wrilten as 45

$$
\frac{d a}{d N}=\left(\gamma_{1}-\gamma_{r}\right) r_{p} \cos \theta
$$

where $\gamma_{r}$ and $\gamma_{r}$ are the the average plastic strain in forward and reverse sllp, $\theta$ represents the favorably oriented slip direction within the plastle zone, and $r_{p}$ is the cyclic plastic zone stre, ${ }^{46}$

$$
r_{p}=\frac{1}{3 \pi}\left(\frac{\Delta K}{2 \sigma_{y}}\right)^{2}
$$

and $\Delta K=K_{\max }-K_{m i n}$ and $\sigma_{y}$ is the yleld stress. The tIme-base CGR da/dt $\left(m \cdot s^{-1}\right)$ is given by

$$
\frac{d a}{d t}=\frac{d a}{d N}\left(\frac{1}{t_{r}}\right)=\frac{\left(\gamma_{f}-\gamma_{p}\right)}{t_{r}} \frac{1}{3 \pi}\left(\frac{\Delta K}{2 \sigma_{y}}\right)^{2} \cos \theta
$$

where $t_{r}$ is the rise time (s) of the posilive sawlooth wave form. When strain hardening of the material is considered, ${ }^{45}$ the CGR compensated for strain hardening can be written as

$$
H \frac{d a}{d t}=H \frac{d a}{d N}\left(\frac{1}{t_{r}}\right)=\frac{\beta}{t_{r}(I-R)} \frac{(\Delta K)^{3}}{\sigma_{y}^{2}}
$$

where $\beta$ is parameter that combines several microstructural and geometric factors, $R$ is the load ratlo $K_{\min } / K_{\max }$, and $H$ is the straln-hardening coefflclent

$$
H=\frac{\sigma_{u}-\sigma_{y}}{\varepsilon_{1}}
$$

where $\sigma_{u}$ and $\sigma_{y}$ are the ultimate tensile and the yleld strengths, respectively, and $\varepsilon_{l}$ is the total strain at fallure of the material. 
In the absence of any environmental eflect on crack growih at a constant rise lime and $\Delta K$ in the Parls replime (power law exponent for $\Delta K$ of $* 3$ ). E(j. 6 Indicales that the strainhardening compensated CCKs. Hl(a/di). should decrease as the yleld strength increases following a $1 / \sigma_{y}{ }^{2}$ dependence. 1. . . I logarllhmle plot of $11\left(d a / d i l\right.$ versus $\sigma_{y}{ }^{2}$ would have a slope of -1. Allhough data for the dependence of Coks on yleld stress are sparse, CCiks compensaled for the straln hardenlug behaviorl of an $0.5 \mathrm{Cr} 0.5 \mathrm{Mo} 0.25 \mathrm{~V}$ steel will different heat trealments, which produce a range of yleld strenglhs. follow this type of dependence in air at amblent temperature 45.47

In the present lests on as recelved and thermally aned cast SSs In high tempernture oxygenated water. the strain hardening compensaled cares tend to increase as the yleld strenglh increases. as shown in Fig. 24. The lines on ench plot in Figs. 23 and 24 represent a slope of 1 , which indicate that the cCiks in oxygenated water. as well as those compensated by the strain hardenink coclifelent, are proportional to oy ${ }^{2}$, In contrast to $1 / \sigma^{2}$ in the case of pure mechanical fatkgue of the ferrille steel in wir.
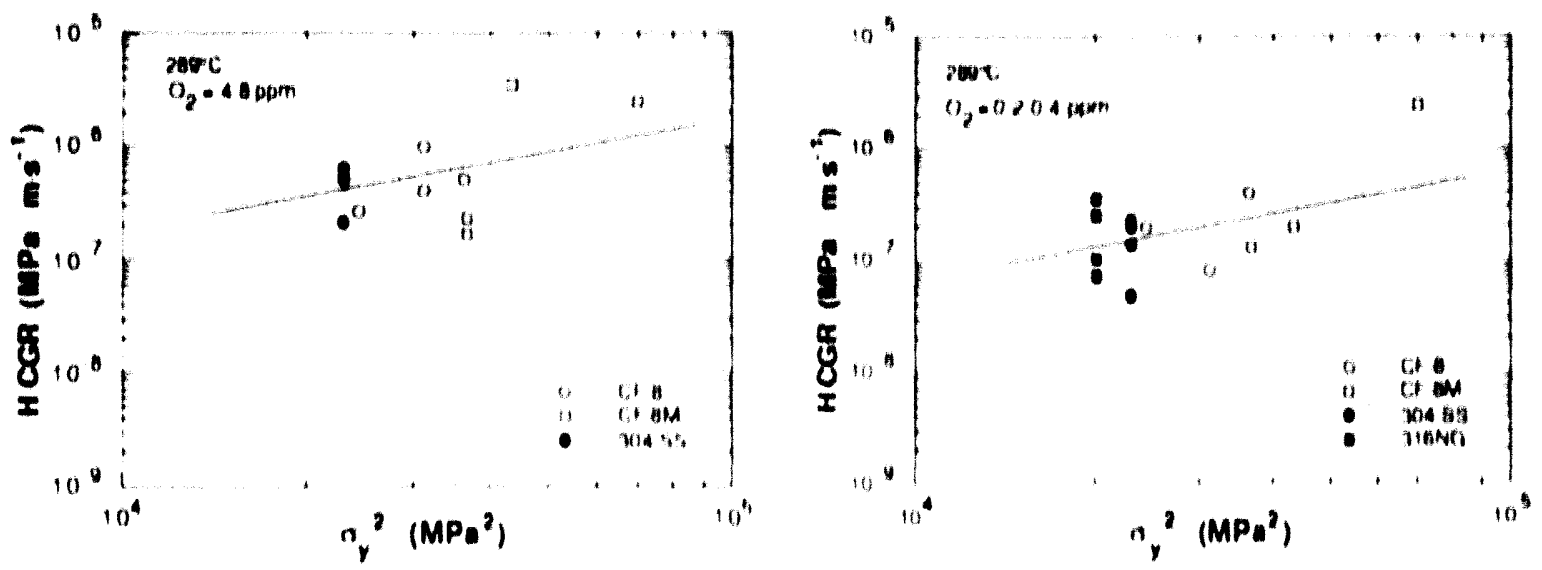

Figure 24. Dependence of straln hardening compensaled coiks of as recoilened and thermally aged ( $\%$ \& and $8 M$ cast SS on yield stre'ss of the matertals at

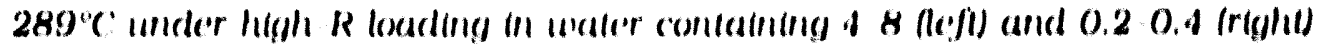

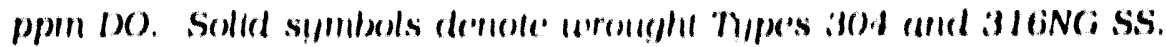

Fracture mechankes cGik lests are In progress on bher heals of cast ss lo determine

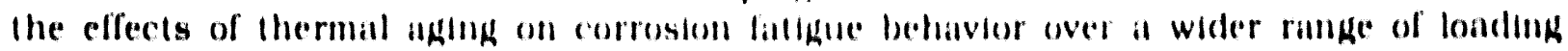
condllions.

\section{Irradlation-Assisted Stress Corrosion Cracking of Austenitlc SS}

In recent years, fallures of renctor core inlermal components in both bWRs and PWRs have increased after accummlatlon of relallvely high nuence $\left(>5 \times 10^{20} \mathrm{ncm}^{2}, \mathrm{E}>1 \mathrm{M} \cdot \mathrm{V}\right)$. The general pattern of the observed fallures indialles that as nuclear plants age and

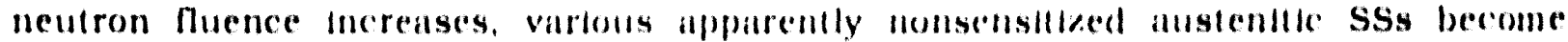
susceptible to intergramular lablure. Some components le. H. BWR control blade handle and sheath) are known to have cracked under mindmal applled sliess. Allhough most labled components can be replaced. some safely slgnifleant structural components, such as the BWR top guade, shroud, and core plille, would be very dilficull or limpractleal to replace. 


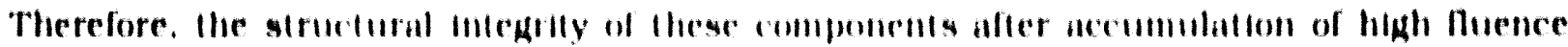
has been a subject of concerth. and extenster research lias been condencted to provide an

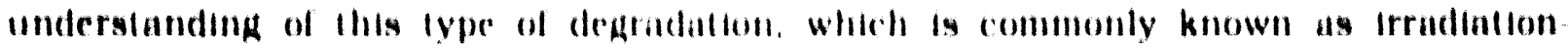

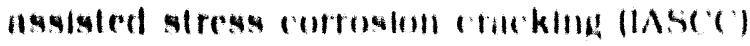

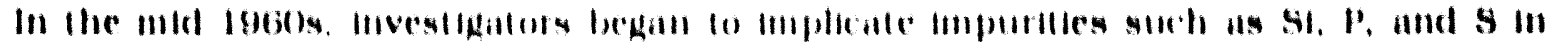

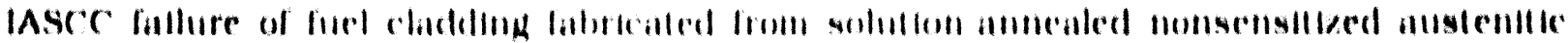

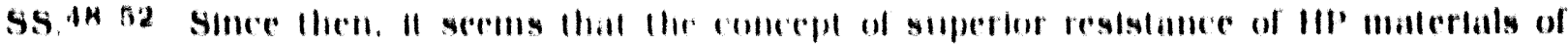

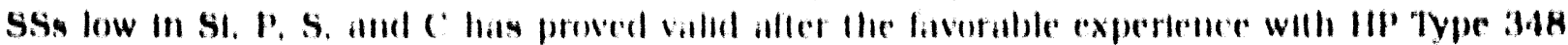

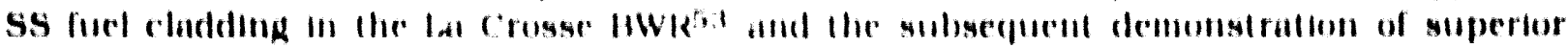

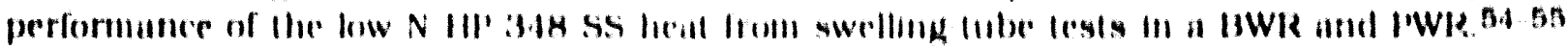

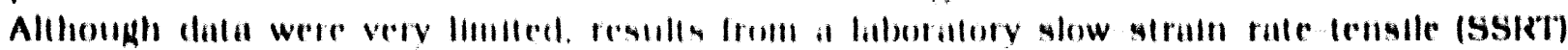

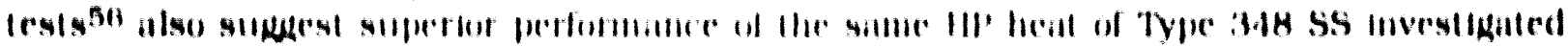

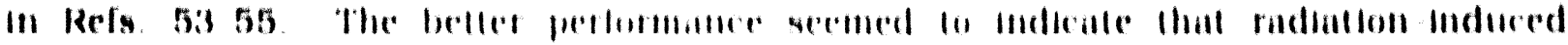

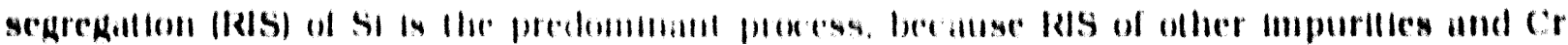

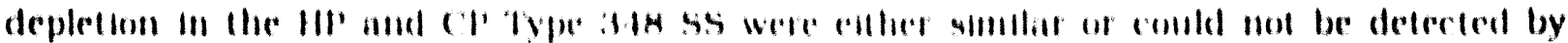

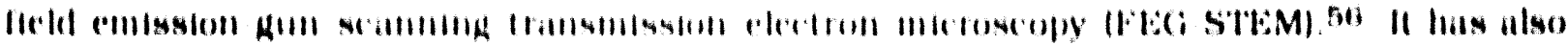

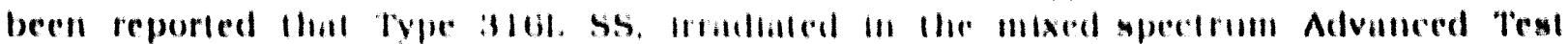

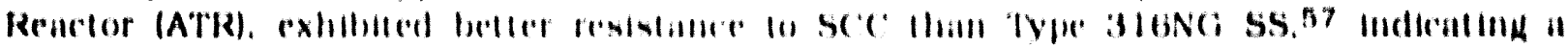

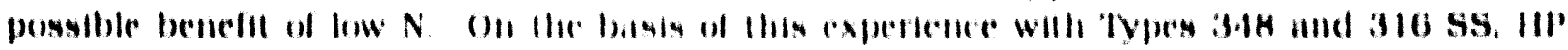

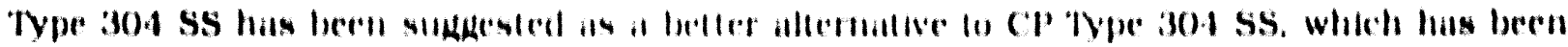

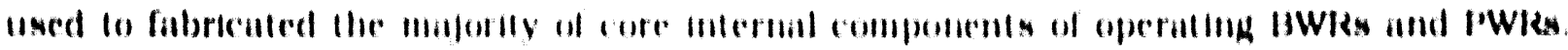

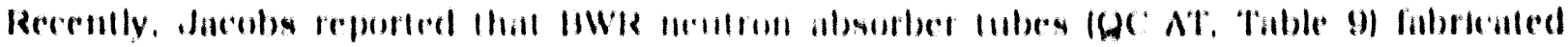

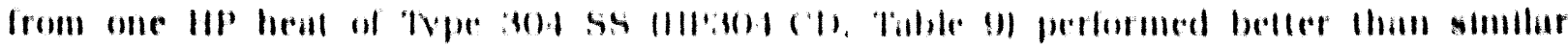

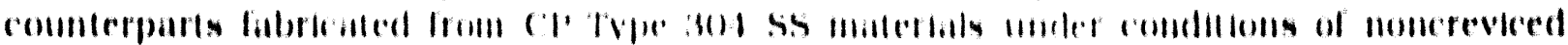
whler chemistry $5 \mathrm{~B}$

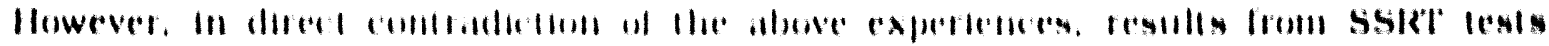

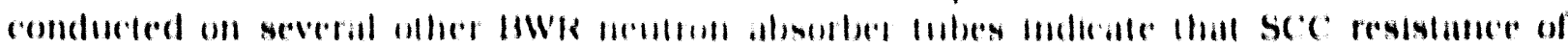

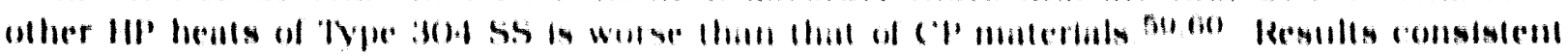

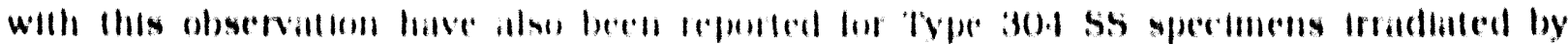

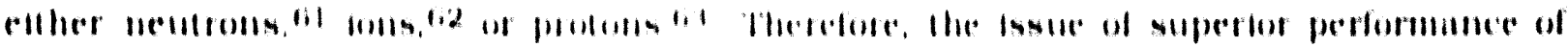

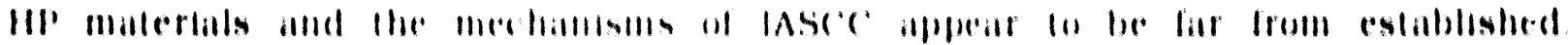

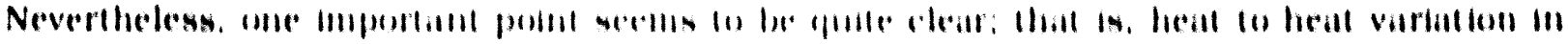
susceptlbillly to IASC '

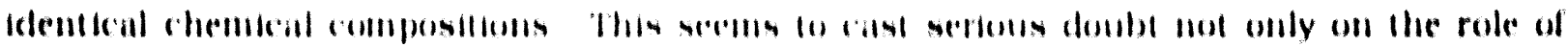

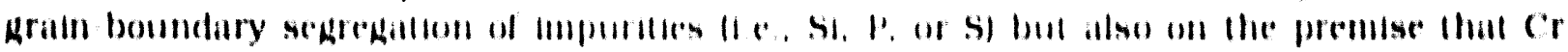
depletlon is he primury merhimmon of inse'

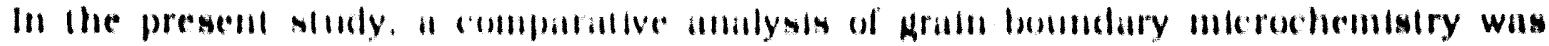

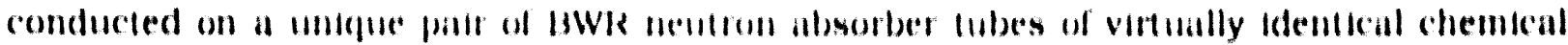

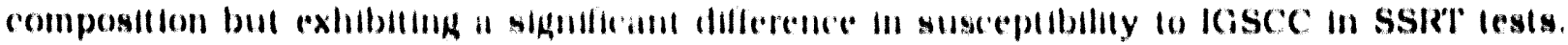

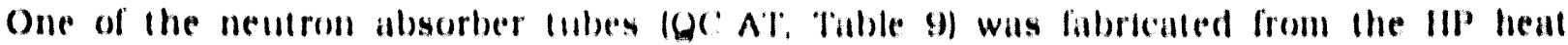

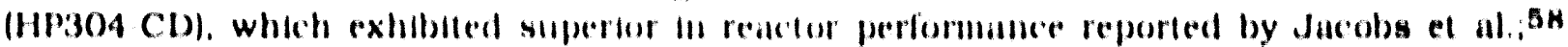
the other neutron absorber lube (V Al) was labrienled from a slmilar IIP leat (IIISBOA A)

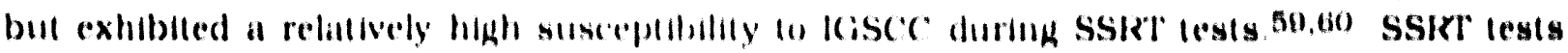
Independent of those in Rels. 59 and 60 were conducled on both mallerlals, and the results 
showed that IOSCC susceptibilly of the former material (QC AT) was lower than that of the latter (V AT) for a similar nuence level." Chemical composillons of the two materlals were virtually Identical except for $\mathrm{N}$ and $\mathrm{B}$ contents. Therefore, a comparative analyals of the iwo materlals was considered to be ideal for invesligaling the significant difference in

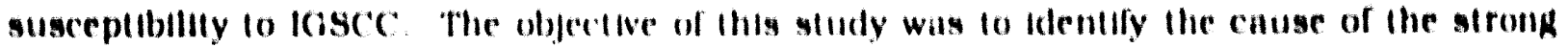
heat to heat vartation of the III inatertals. theteby providing an important clie to the primary process that influences IASCC of anslenille SSs

\subsection{8usceptiblilty to Intergranular Cracking In Wator and In Vacuo (H. M. Chung, W. E. Ruther, and J. E. Banocki)}

Specimen preparallon. procedures for ssirr lests. and a descriptlon of the hol cell Ssket apparalus were diven in previous reports 50.00 Cylindrical tenslle specimens were

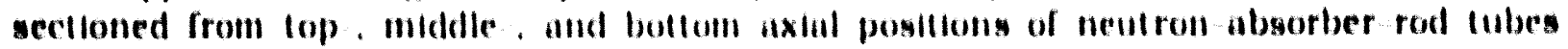

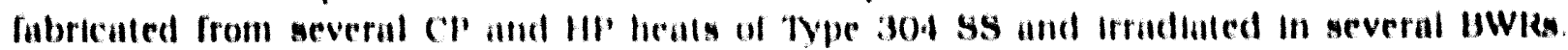

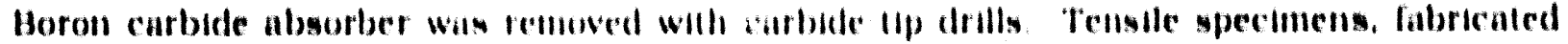

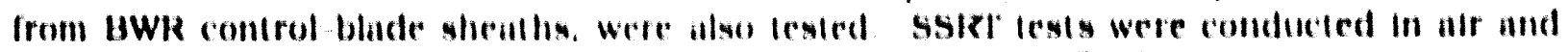

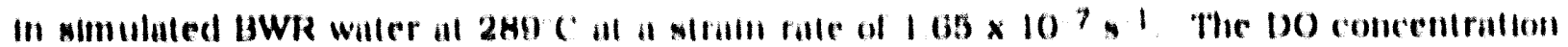

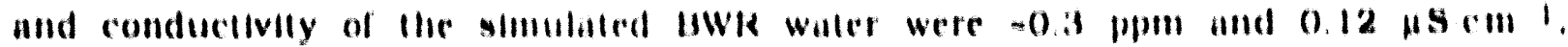

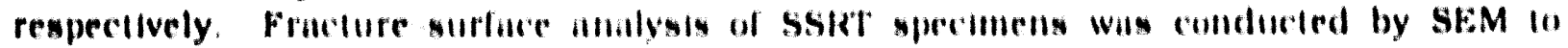

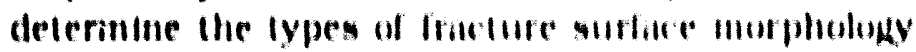

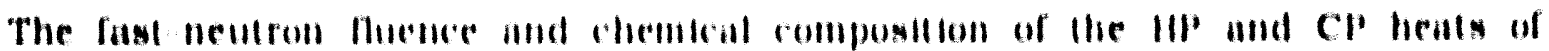

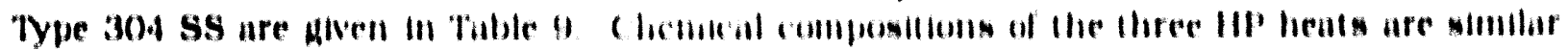

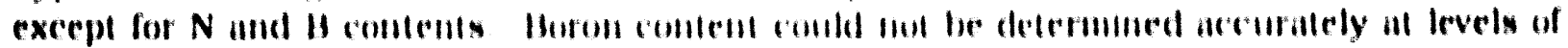

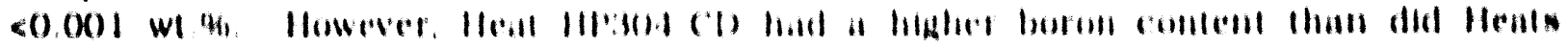
III:304 $A$ or 13

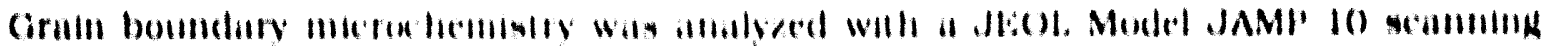

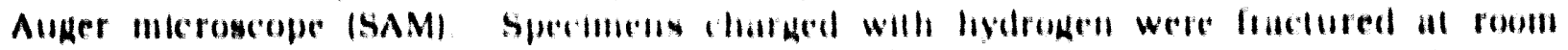

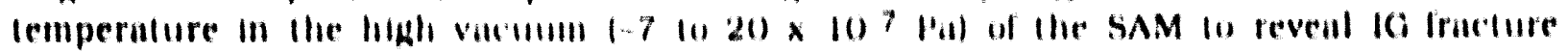

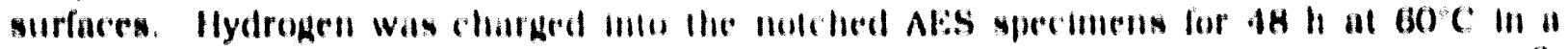

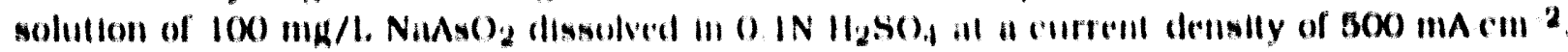

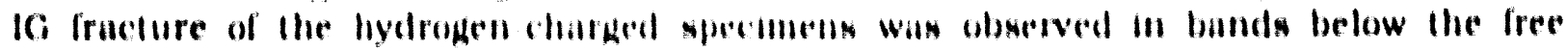

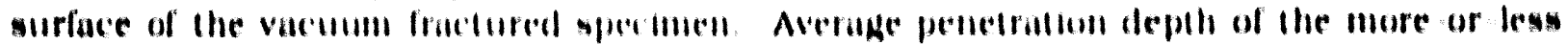

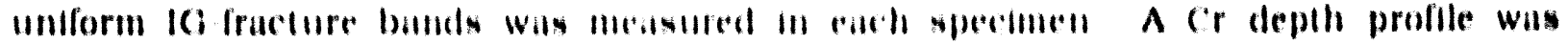

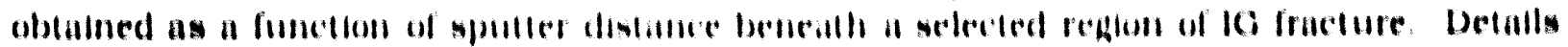
of the procedure ale pliven in ket (i)

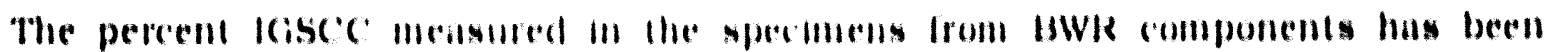

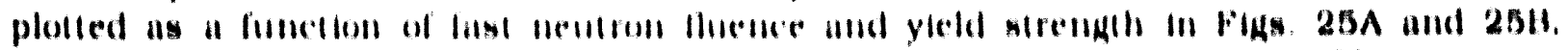

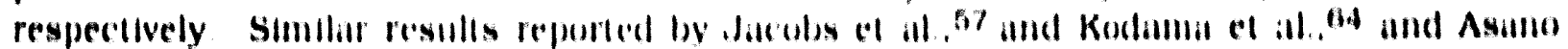

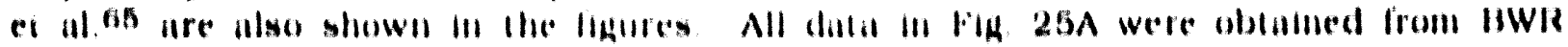

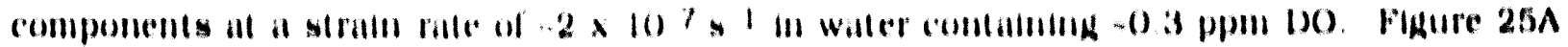

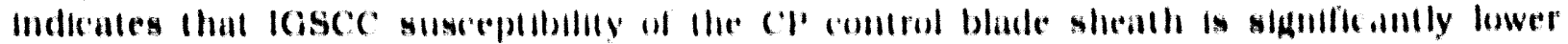

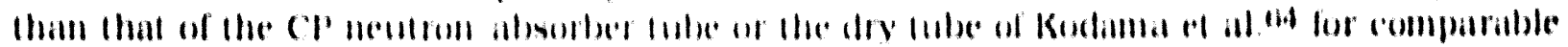

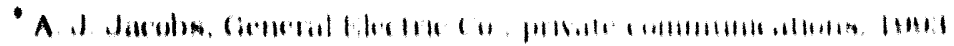


fluence level. The susceptibllity of the III' ubsorber tube is greater than that of any of the Ce materials.

Table 9. Chemical composilion and fluente of HP and (D) Type 304 SS DWR componen:s

\begin{tabular}{|c|c|c|c|c|c|c|c|c|c|c|c|c|}
\hline \multirow{2}{*}{$\begin{array}{l}\text { llinal } \\
\text { III No }\end{array}$} & \multicolumn{9}{|c|}{ Complonsllion (w) } & \multirow{2}{*}{$\begin{array}{l}\text { suirer } \\
\text { coute }\end{array}$} & \multirow{2}{*}{$\begin{array}{l}\text { Service } \\
\text { Neactor }\end{array}$} & \multirow{2}{*}{$\begin{array}{c}\text { Flupnce } \\
10^{21} \\
n \mathrm{~cm}^{-2}\end{array}$} \\
\hline & $\mathrm{Cl}$ & Ni & $M n$ & c & N & II & $\$ 1$ & ' & $\mathbf{s}$ & & & \\
\hline $111164 \AA$ & $\ln 60$ & 446 & $\mid \mathrm{kI}$ & 0018 & $0 \mid(1)$ & .0001 & .001 & 0008 & 0004 & V. $\wedge^{\prime} \mid \mathbf{H}$ & Inwil| & 0214 \\
\hline 11126411 & In: & 47 & $1 n$ & ools & now) & .0001 & oon & ocon & $0.00 \mathrm{~s}$ & $V: A I^{\prime \prime}$ & InWhII & 0211 \\
\hline $11: \cdot 1)(1)$ & $\ln n$ & $\| 44$ & 122 & 0017 & $00: 17$ & $f(x))$ & 0.02 & 0.002 & $0(x) 3$ & $V A T^{*}$ & Imw||| & 0.21 .4 \\
\hline $111 \times 04(1)$ & In & 444 & 122 & 0017 & 0017 & $0(00)$ & 0.02 & $0.0 \times 9$ & $0\left(\mathbf{C O}^{\prime}\right)$ & $\Delta C \wedge$ ค'น & Invine & 20 \\
\hline Cl.104 & (nn) & 477 & 100 & $0 \mathrm{CH}$ & oora & & $1 \mathrm{~m}$ & 004515 & $0.0 .0 \%$ & III. AIr & IIWISY & 022.0 \\
\hline CHod II & 140.200 & ค 10 ก & 2104 & $0.0 \mathrm{n}^{\prime \prime}$ & & & $1000^{b}$ & $004 n^{\prime}$ & 0.030 " & $1 C \mathrm{sd}^{\mathrm{d}}$ & INWIIIC & 0.520 \\
\hline
\end{tabular}

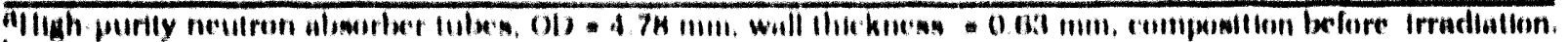

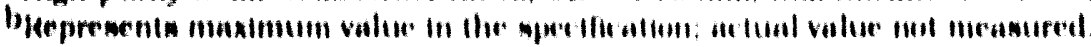

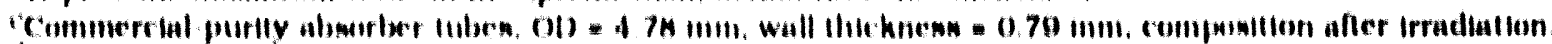

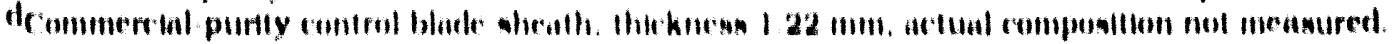

Apparenlly, II Hood correlilion is observed between percent IOSCC and yield strength (Fid. 25B3). For eximple, the CD Type 304 ss shealli from the La Croane BWR exhlbits

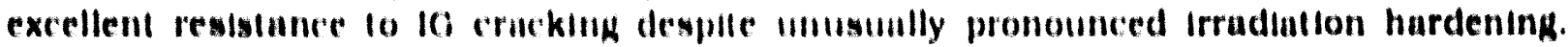

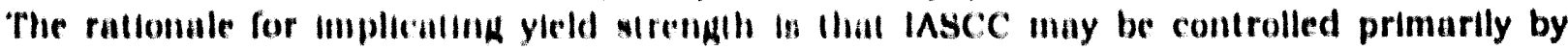

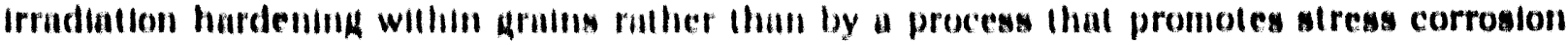
at the arain boundaries. However, lhe results in Fin. 25 is indicule that although irradintion. Induced hurdening promoles ICSCC by rendering plaslle deformatlon wilhin gralns more

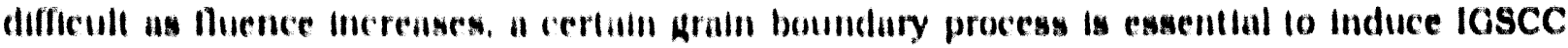
III Irradinled mulerials
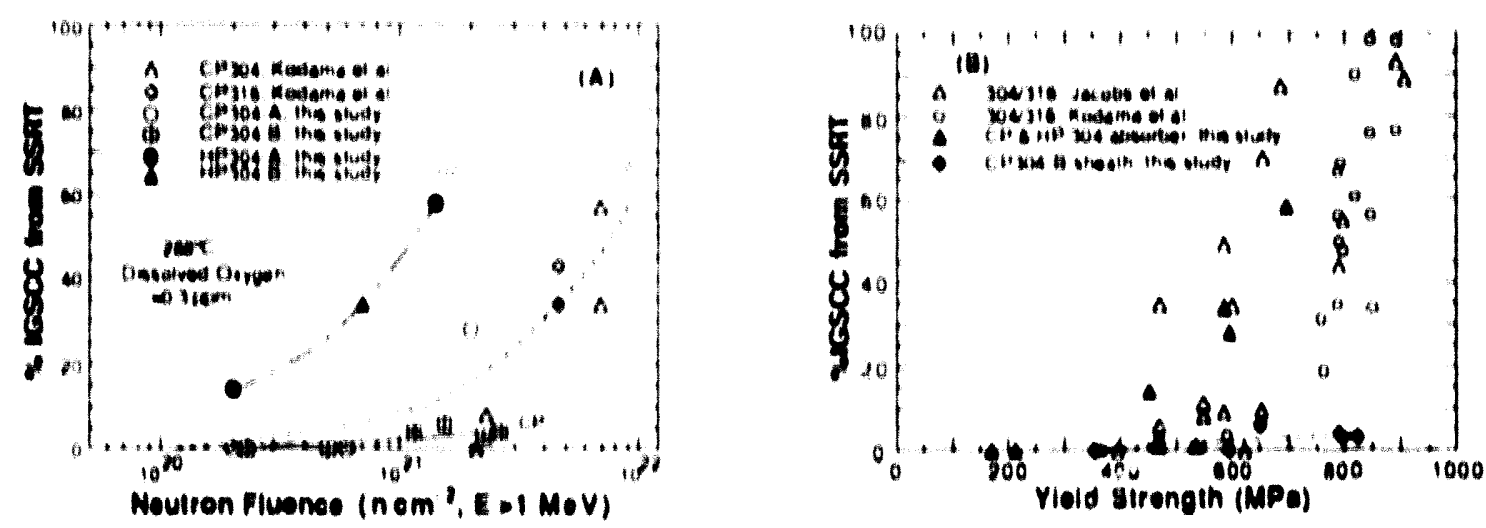

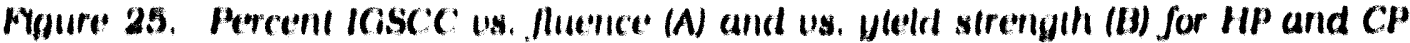
Type IOA SS and CP 316 SS HWR components from SSRT tests at 289"C in stmulated HWR water 


\subsection{Effect of Grain-Boundary Mlcrochemletry (H. M. Chung, W. E. Ruther, and}

\section{J. E. sancokl)}

\subsubsection{Efreote of $S 1, P_{1}$ and $S$}

In Fig. 26, the percent IGSCC from the SSRT lests In water has been plotted as function of grain-boundary concentration of $S I$ and $P$. Data lor grain-boundary segregation of SI. P, and other impurities have been reported in Rels. 59 and 60. In the ligure. the depth of 10 -fracture penetration, produced in hydrogen-charged specimens in vacuo at $25^{\circ} \mathrm{C}$, has been also plotted. The $x(59-\mathrm{eV})$ peak shown in Fis. $26 \mathrm{C}$ is produced by the secondary Auger electrons of LI and NI. A more detalled analysis of the identification of the peak is given below. No evidence of segregation of $S$ was observed. 30
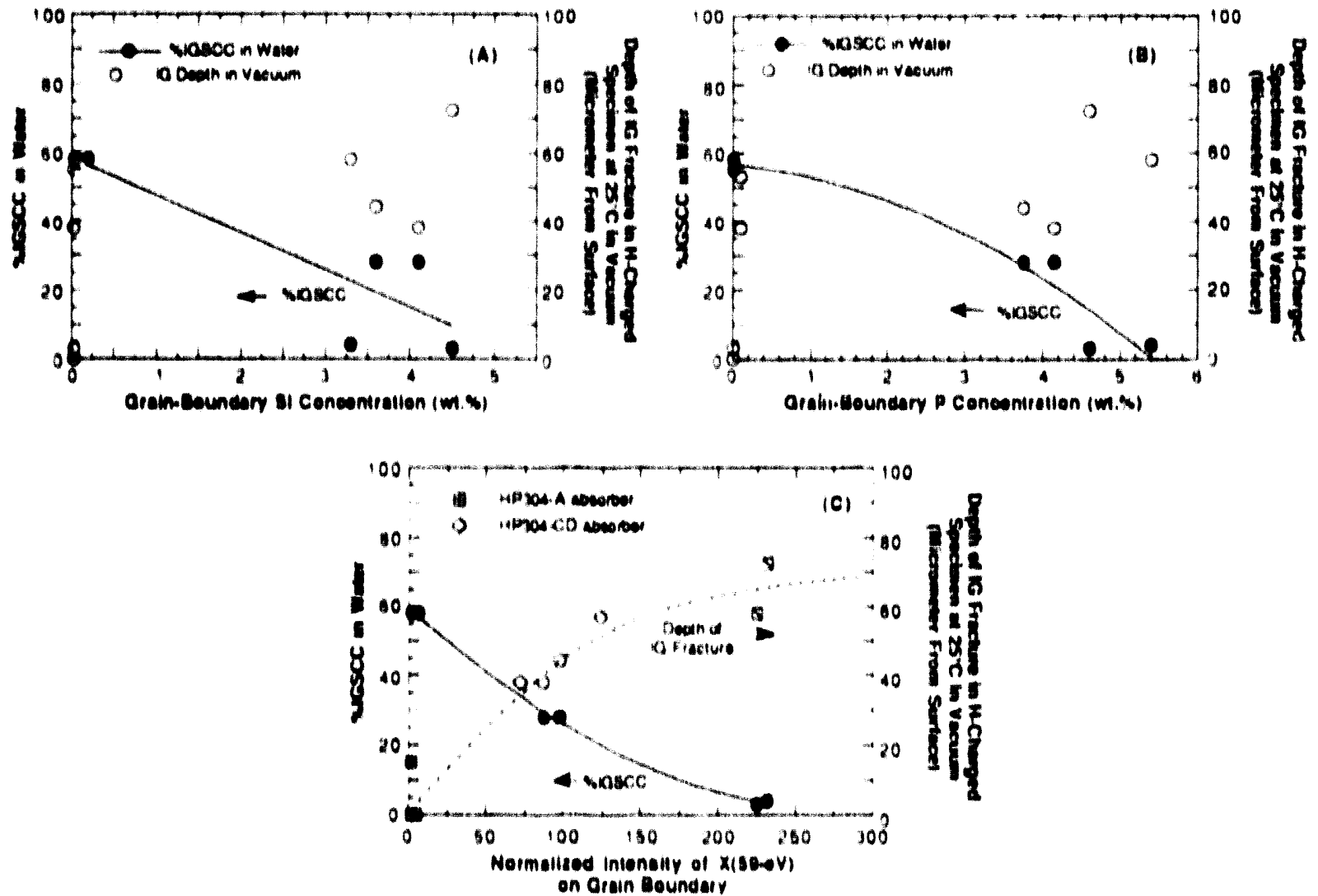

Figure 26. Percent ICSCC in water and depth of IC fracture penetration in hydrogen charged spectmens, fractured at 25 "C in vacuo, as a function of grain-boundary segregation of $S(A), P(B)$, and $\times(59 \cdot \mathrm{eV}(C)$. Fluence level of the specimens was $-2 \times 10^{21} \mathrm{n.cm} \mathrm{cm}^{2}$.

No good correlation was observed between the susceptibility to hydrogen-enhanced IG cracking and grain boundary concentration of SI or P. Percent ICSCC in vater decreases monotonically for increased grain boundary concentratlons of SI, P, and X(59-eV). It is difficult, therefore. to explain the significant IGSCC in the HP absorber tube specimens or the negligible SCC susceptibility of the CP sheath specimens on the basis of grain-boundary segregation of SI. P, or S. The present results show convincingly that grain-boundary segregation of SI. P. or S is not the mechanism of IASCC In Type 304 SS, as has been 
speculated up to now. Furthermore, the results also strongly imply that low SI, P, and $\mathbf{S}$ content is not the primary factor associated with the superior resistance of the HP Type 348 SS reported in Refs. 53 56.

\subsubsection{Effect of Cr Depletion}

Minimum Cr content on grain boundarles of the $\mathrm{CP}$ and $\mathrm{HP}$ absorber tubes and controlblade sheath was determined from AES depth prolile data, and the values were correlated with percent IGSCC in Fig. 27. In the ligure, simular results obtained from the FEG-STEM lechnlque $56,65,66$ are also plotled for comparison. The latler results were obtained on SSRT specimens tested in simulated BWR water containing $8.32 \mathrm{ppm}$ of dissolved oxygen. For a better comparison, the percent IGSCC from the present SSR'T tests in water with $=0.3 \mathrm{ppm}$ dissolved oxygen was extrapolated 10 an oxygen content of $8.32 \mathrm{ppm}$ according to the trend reported by Kodama ef al. ${ }^{64}$ A comparison similar to that in Fig. 27 has been discussed by Bruemmer el al. 67

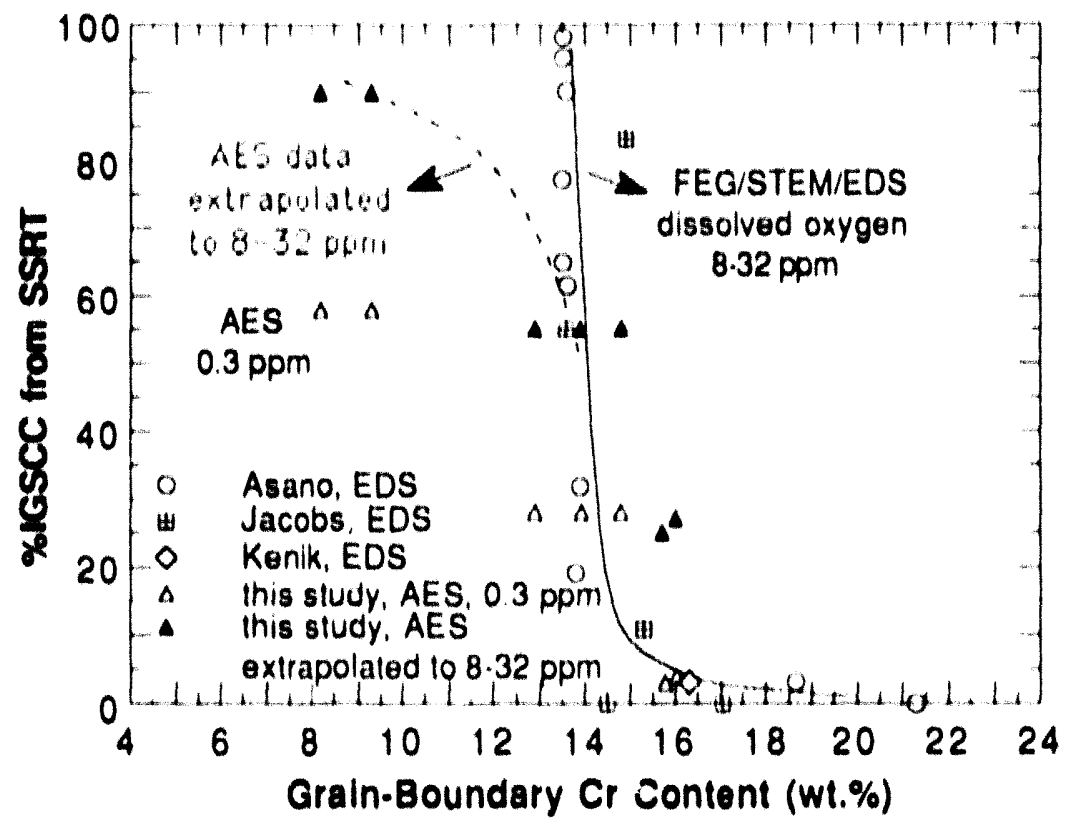

Fyoure 27. Percent IGSCC from SSRT tests us. minimum grain-boundary $\mathrm{Cr}$ content deternined from AES and HEG STEM analyses of BWR components

Results of analyses by the two techulcues appear to be consistent except for the HP Heat HP304.A. In which the $\mathrm{Cr}$ depletion proflle is exiremely narrow and deep according 10 AFs. A more direct comparison has been reported elsewhere 60 Figure 27 lends itself to several interpretations; one is that present generation FEG STEM referred to in Fig. 27 has limitations in detecting $\mathrm{Cr}$ at a concentration of $<14 \mathrm{wt} . \%$ within $-1.5 \mathrm{~nm}$ of a grain boundary in BWR Irradlated materials. This may be because of several inevitable limitatluns assoclated with the energy-disperslve spectroscopy (EDS) technlque in present-generation FEG.STEM, 1.e., effects of imperfect grain-boundary alignment (1-nm uncertainty from $1^{\circ}$ misalignment in a $57 \mathrm{~nm}$ thick (Illm), the relatlvely large beam si\%e $(-2.5 \mathrm{~nm}),{ }^{68,69}$ beam broadening. ${ }^{68.68}$ the effect of the $\mathrm{Cr}_{2} \mathrm{O}_{3}$ surface layer, and lluoresced $\mathrm{Cr} \mathrm{X}$-ray, ${ }^{56}$ Because of 
these limitations, practical resolution of the present-generation FED-STEM-EDS analysis should be considered close to 3.5-4 nm. The resolution limit can be greatly improved by utilizing the technique of electron-energy-loss spectroscopy (EELS) instead of EDS.69 AES data can also be inflienced by oxygen contamination from the microscope vacuum environment.

Without a proper understanding of the limitations of the techniques and uncertainties of the measurements, and in the absence of a more convincing database le.g., data from EELS in a next-generation FEG-STEM), the role of grain-boundary $\mathrm{Cr}$ depletion cannot be determiried convincingly at present. Based on either FEG-STEM or AES data, Fig. 27 suggests that for $<30 \%$ IGSCC, susceptiblity is influenced significantly by $\mathrm{Cr}$ depletion. However, the seemingly strong increase in percent IGSCC despite the nearly constant grain-boundary $\mathrm{Cr}$ content of $\approx 14-15 \mathrm{wt} . \%$ (FEG-STEM data) implies that an unidentified process other than $\mathrm{Cr}$ depletion plays an important role. According to AES data, $\mathrm{Cr}$ depletion plays an Impoitant role even for $>50 \%$ IGSCC.

\subsubsection{Comparative Analysis of Similar High-Purity Heats}

To provide a clue to the question of whether one or more unidentified processes play an important role in IASCC, a case study was conducted using absorber tube specimens that were fabricated from two virtually identical HP heats (HP304-A. less resistant to IGSCC during SSRT, 59," and HP304 $-\mathrm{CD}$, more resistant to IGSCC/SSRT) irradiated to a fluence level of $\approx 2.0 \times 10^{21} \mathrm{n} \cdot \mathrm{cm}^{-2}$. The rationale was that because Si, P. S, C, Ni, Cr, Mn, and fluence levels were similar in the two heats, graln-boundary concentrations of these elements and irradiation-induced hardening should be similar. Therefore, It should be relatively easy to identify other aspects of grain-boundary chemistry that could be correlated with resistance to IGSCC. The two materials also exhibited a surprisingly large difference in their susceptibllities to IG fracture in vacuo after $\mathrm{H}$-charging (see Fig. 26C). In contrast to HP304-CD, it was very difficult to produce IG fracture in vacuo in $\mathrm{H}$-charged specimens of HP304-A, a trend opposite to susceptibility to IGSCC in water. Grainboundary $\mathrm{Cr}$ depletion in the two specimens, determined by AES depth-profiling, is shown in Fig. 28. Not surprisingly, $\mathrm{Cr}$ depletion in the specimens was similar because of a virtually identical chemical composition and similar fluence.

Grain-boundar: segregation behavior of $\mathrm{Ni}$ and impuritles in the two specimens is summarized in Fig. 29. In the figure, segregation behavior of Ni, Si, P, C, S, N, X(59-eV), and $\mathrm{B}$ can be determined by comparing intensilies of the elements on ductile (denoted "D") and intergranular (denoted "l") fracture surfaces. The left- and right-hand columns of Fig. 29 show results measured on HP304-A and HP304-CD specimens, respectively. In Fig. 30, duplicate results obtained from another specimen of HP304-CD are shown. Whencver grain-boundary segregation is clearly indicated for a given element, a horizontal line shows the average intensity of the element on grain boundaries, e.g., Ni in HP304-A (Fig. 29A). In the HP304-A specimen, only Ni segregation was evident. In the HP304-CD specimen, grain-boundary segregation of not only $\mathrm{N} 1$ but $\mathrm{N}, \mathrm{X}(59-\mathrm{eV})$, and $\mathrm{B}$ was evident. Figures $29 \mathrm{H}$ and 30D indicate segregation of $\mathrm{C}$ in the two specimens of HP304-CD, but the evidence seems less convincing.

\footnotetext{
A. J. Jacobs, General Electric Co., private communications, 1993.
} 


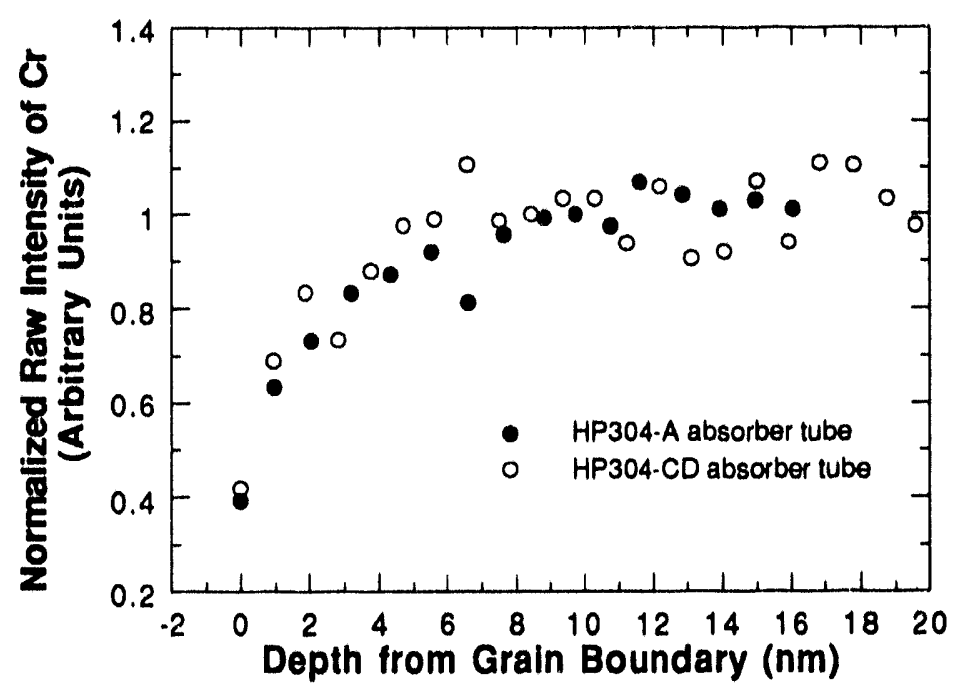

Figure 28. Comparison of grain-boundary Cr-depletion profles determined from AES analyses of HP304-A and HP304-CD absorber tubes irradiated to $2 \times 10^{21} \mathrm{n} \cdot \mathrm{cm}^{-2}$

\subsubsection{Identification of Li on Grain Boundaries}

To Identify the X(59-eV) peak. Auger spectra were obtained from several types of CP Type 304 SS specimens, 1.e., irradiated, nonirradiated, and corroded in liquid LI (because this element, which is produced by thermal-neutron transmutation of ${ }_{5} \mathrm{~B}^{10}$, may contribute to the peak). The results are summarized in Fig. 31. The X(59-eV) peak was observed in Auger spectra obtained from: (a) Irradiated Type 304 SS BWR components (Fig. 31D). (b) nonirradiated Type $304 \mathrm{SS}$ specimens that were corroded in liquid lithium at $600^{\circ} \mathrm{C}$ for $144 \mathrm{~h}$ (Fig. 31B), nonirradiated Type $310 \mathrm{SS}$ containing $20 \mathrm{wt} \% \mathrm{Ni}$ (Fig. 31C), and (c) nonirradiated Type 330 SS containing $35 \mathrm{wt} . \% \mathrm{Ni}$. The characteristic shape of the peak observed in nonirradiated Type 310 SS was somewhat different from those observed in the Li-corroded, nonirradiated, and Irradiated Type 304 SS specimens. The peak was absent in nonirradiated specimens of Types 304, 347. AISI 3340, and martensitic SS, as shown more quantitatively in Fig. 32.

These results show that at least some fraction of the intensity of the $X(59-\mathrm{eV})$ peak observed in specimens of HP304-CD (Figs. 290 and 30G) is due to LI. Results in Figs. 29A. 29E, and 30A show that Ni-segregation ratios in the HP304-A and HP304-CD specimens are virtually identical. Because the bulk concentration of $\mathrm{NI}$ is virtually the same (1.e., 9.45 wt.\%; see Table 9), the grain-boundary concentration of $\mathrm{Ni}$ in the two specimens should be similar. Accordingly, it is difficult to attribute the large difference in the intensity of X(59-eV) between HP304-A (Fig. 29K) and HP304-CD (Fig. 29O) to grainboundary concentrations of Ni. The segregation behavior of X(59-eV) (Figs. 290 and 30G) and $B$ (Figs. 29P and $30 \mathrm{H}$ ) in HP304-CD was also similar. Therefore, we conclude that the $\mathrm{X}(59-\mathrm{eV})$ peak observed on the grain boundaries of HP304-CD is in fact the secondary peak $(\approx 58 \mathrm{eV})$ of $\mathrm{Ll}$, whereas the primary peak of $\mathrm{LI}(\approx 43 \mathrm{eV})$ was superimposed on the $47-\mathrm{eV}$ peak of $\mathrm{Fe}$. 

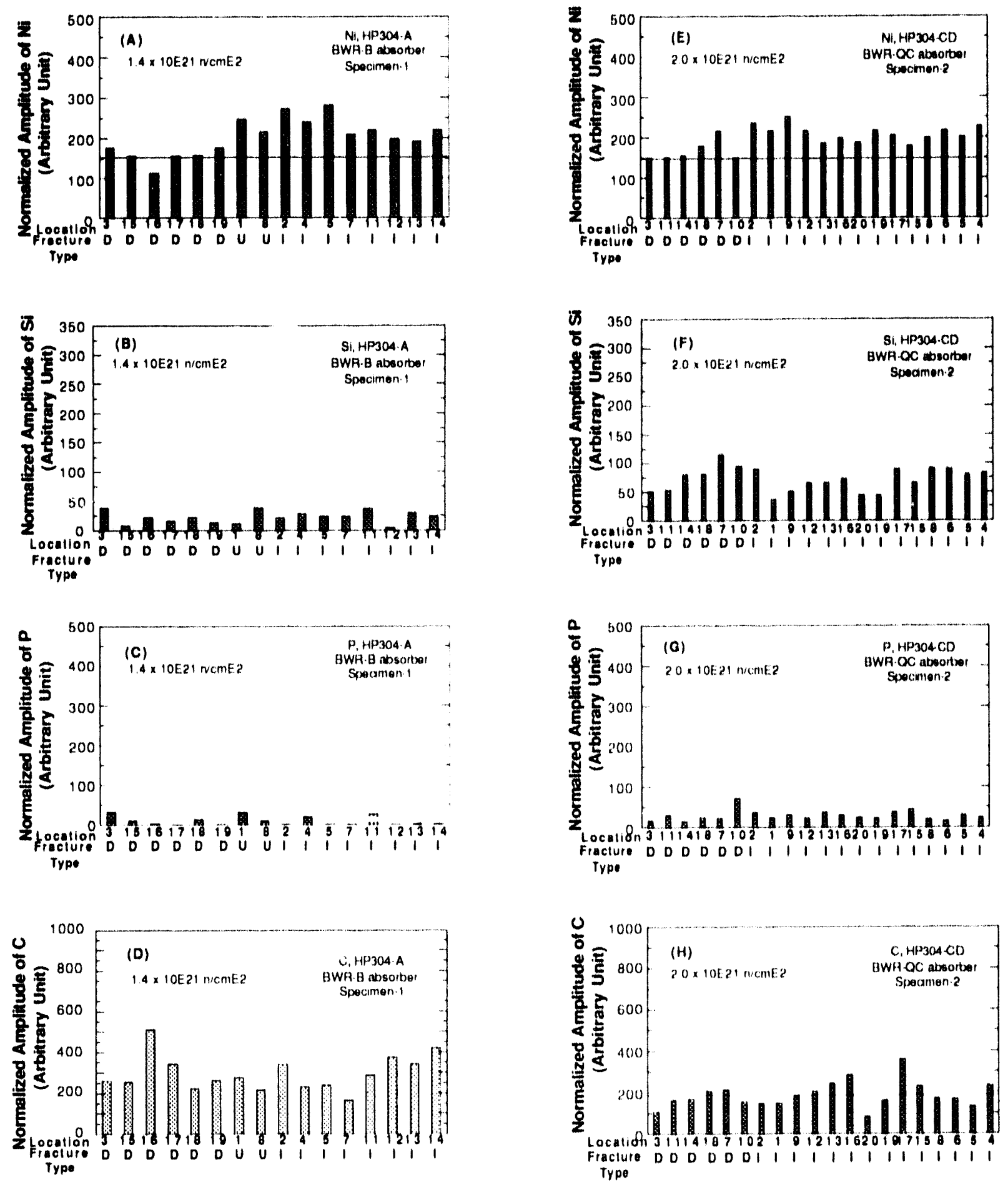

Figure 29. Intensities of $N i, S t, P$, and C signals from ductile (denoted by "D"). intergranular ("I"), and faceted ("U"), fracture surfaces of neutron absorber thbes fabricated from the HP heats IIP304 A (A to D) and HP304 CD (E to H) and irradiated $t o=1.4 \times 10^{21}$ and $=2.0 \times 10^{21} 11 \mathrm{~cm}^{-2}$. respectively. Intensities of $S, N, X(59 \mathrm{eV})$, and $B$ signals from the HP heats IIP:304 A (I to L) and HP3O4 CD (M to P). 

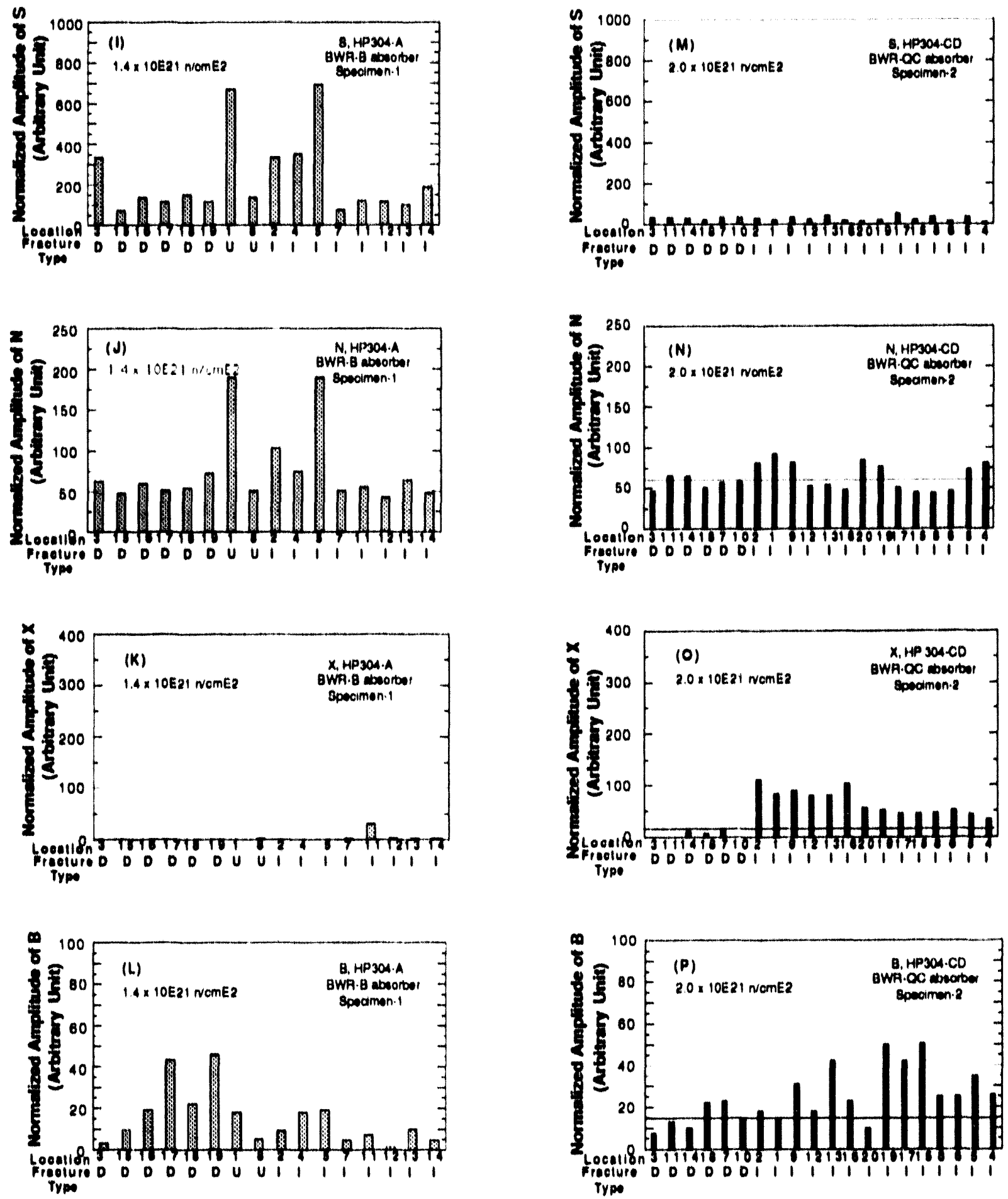

Fygure 29. (Cont'd) 

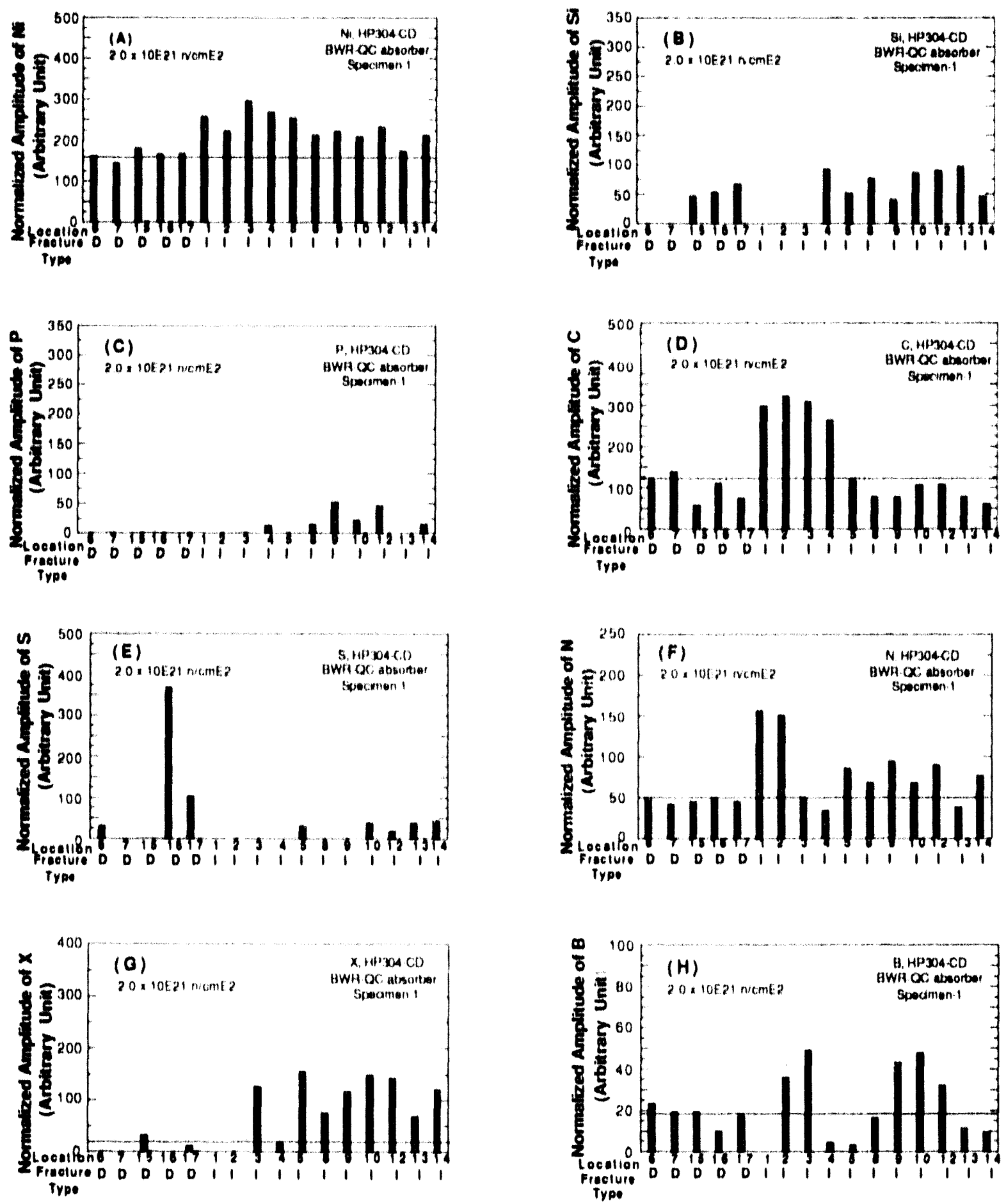

Figure 30. Intensilies of $N i$, Si, $P, C, S, N, \times(59 \mathrm{eV})$, and B signals (A to H) from ductlle (denoted by "D"). intergranular ("I"), and faceted ("U") fracture surfaces of a duplicate specimen of neatron absorber lube fabricaled from HP heat IIP'3()4 (D) and irtadialed to $=2.0 \times 10^{21} 11 \mathrm{~cm}^{2}$ 
As was mentioned previously, Li is produced from transmulation by thermal neutrons of ${ }^{10} \mathrm{~B}$ dissolved in the BWR specimens. 1.e., ${ }^{10} \mathrm{~B}\left(\mathrm{n}\right.$. He) ${ }^{7} \mathrm{LL}$. The cross section for this reaction is large, 1.e., $\approx 3840$ barn. Natural $B$ dissolved in the absorber tubes is composed of $19.8 \% 10_{\mathrm{B}}$ and $80.2 \% 11 \mathrm{~B}$. However, If is not clear if one can rule out the posslbillty that some of the $\mathrm{L}$ atoms detected in the absorber rod tubes came from the $\mathrm{B}_{4} \mathrm{C}$ absorber that is enriched in $10 \mathrm{~B}$.

Boron in austenlic steels is known to segregate sirongly to grain boundaries by thermal processes. Therefore, grain boundary concentrations of $\mathrm{B}$, and hence $\mathrm{L}$, could be Influenced during fabrication of the absorber tubes, even if the tubes were extruded from the same starting materlal. During slow cooling of thick sections (e.g., a BWR top gulde). thermal segregation of $B$ is likely to be more pronounced. When segregated $10_{B}$ transmutes to $\mathrm{LI}$ and hellum. $\mathrm{Ll}$ will be scallered away from the vicinity of grain boundarles because of recoll energy from the transmutatlon. In this slluation, $L$ in the HP304.CD specimens segregates in significant quantily to grain boundaries vla a RIS process because the grainboundary reglons are relatively rich in L. L.lthlum segregation in HP3O4-A was negliglble apparently because the bulk concentration of $B$ was lower (Table 9 ) and $B$ did not segregate to grain boundaries (FIg. 29L).

\subsubsection{Grain-Boundary-Segregation-Transmutation (GST) Synergism: Effects of $N$ and $B$}

Based on the grain-boundary depletion and segregatlon behavior shown in Figs. 28-30 and the bulk chemical compositions given in Table 9, grain-boundary concentrations of alloying and impurily elements in the HP304-A and HP304.CD specimens have been calculated and plotled in Fig. 33. The grain-boundary concentrations were normalized in the plot to factlitate an easy comparison for the two materials, with actual numbers given for each of the elements. Figure 33 shows that grain-boundary concentratlons of the two materials are virtually the same except for $N, L$, and B. Grain-boundary concentraltons of $\mathrm{Cr}, \mathrm{N}$, SI, P, C, and S are similar. Therefore, we conclude that higher concentration of $\mathrm{N}$ and lower concentrations of $L I$ and $B$ on graln boundarles are assoclated with the higher susceptibility of the HP3O4 A materlal to IGSCC during SSRT tests.

The exact mechanism by whlch higher $N$ on grain boundarles promotes IGSCC is not clear. However, segregation of $N$ will result in a higher concentration of hydrogen in a grain-boundary crack-1lp region because of the (ransmutation of $\mathrm{N}$ to hydrogen (proton) by thermal neutrons, 1.e. ${ }^{14} \mathrm{~N}(n, p)^{14} \mathrm{C}$. The cross section for this reaction is $\approx 1.83$ barn. The mechanism whereby a higher $L$ concentration on grain boundaries is conduclve to lower susceptlbillty to IGSCC is also not clear. Lilhlum, however, can trap hydrogen on grain boundarles.

The present study indicates that a synergism between grain-boundary segregation of Impuritles ( $\mathrm{N}$ and $\mathrm{B}$ ) and transmutation by thermal neutrons ("GST" synergism) plays an important role in IASCC. II also suggests that the relative importance of grain-boundary $\mathrm{Cr}$ depletion may be not as great as prevlously belleved. 


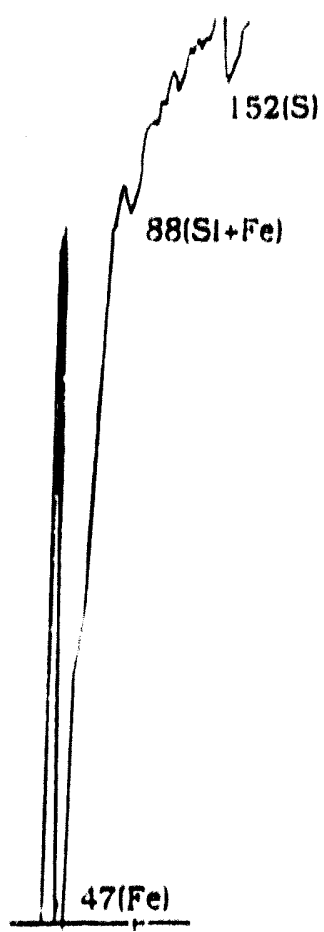

(A) Unirradiated CP 304 SS
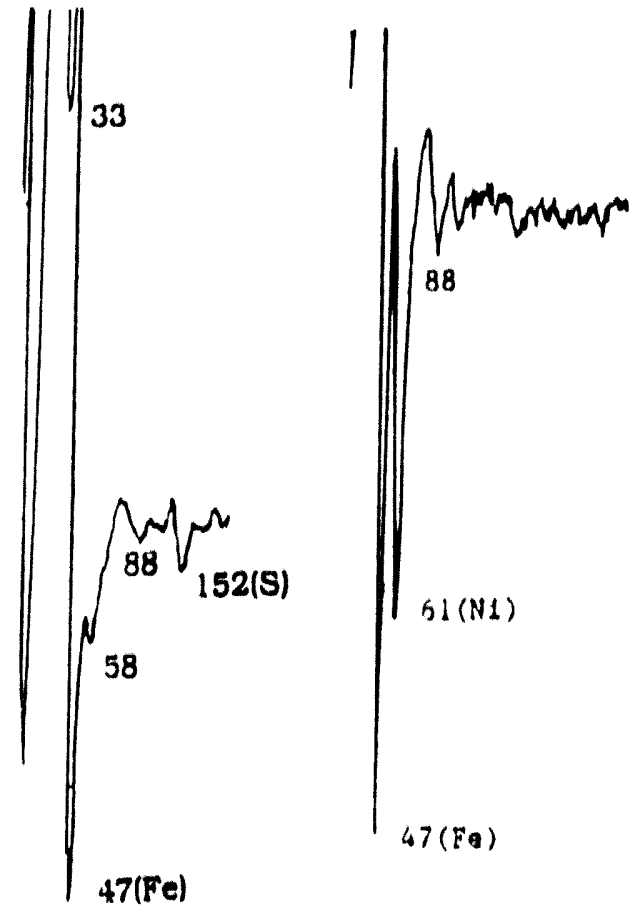

(B) Unirradiated
CP 304 SS
Corroded in L

(C) Unirradiated CP 310 SS

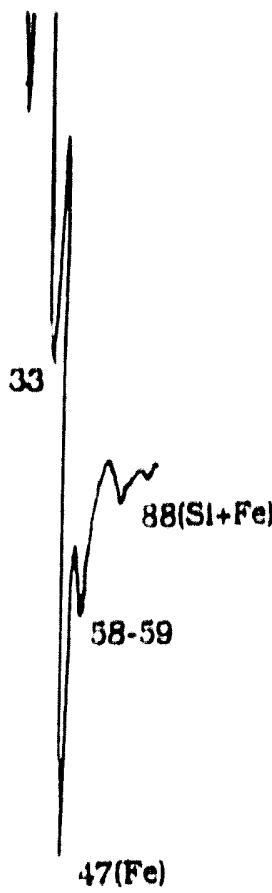

(D)

Imadiated CP 304 SS Grain Boundary

Figure 31. Characteristic $59 \cdot e V$ Auner electron peaks obtained from several SSs; (A) nonirradiated CP Type 304: (B) Type 304 SS nonirradiated and corroded in liquid $L i$ at $600^{\circ} \mathrm{C}$ for $144 \mathrm{~h}$ : (C) nonimadiated Type 310 SS containing $20 \mathrm{wt} . \% \mathrm{Nt}$; and (D) CP Type 304 SS irradiated to $2 \times 10^{21} \mathrm{n} \cdot \mathrm{cm}^{-2}$

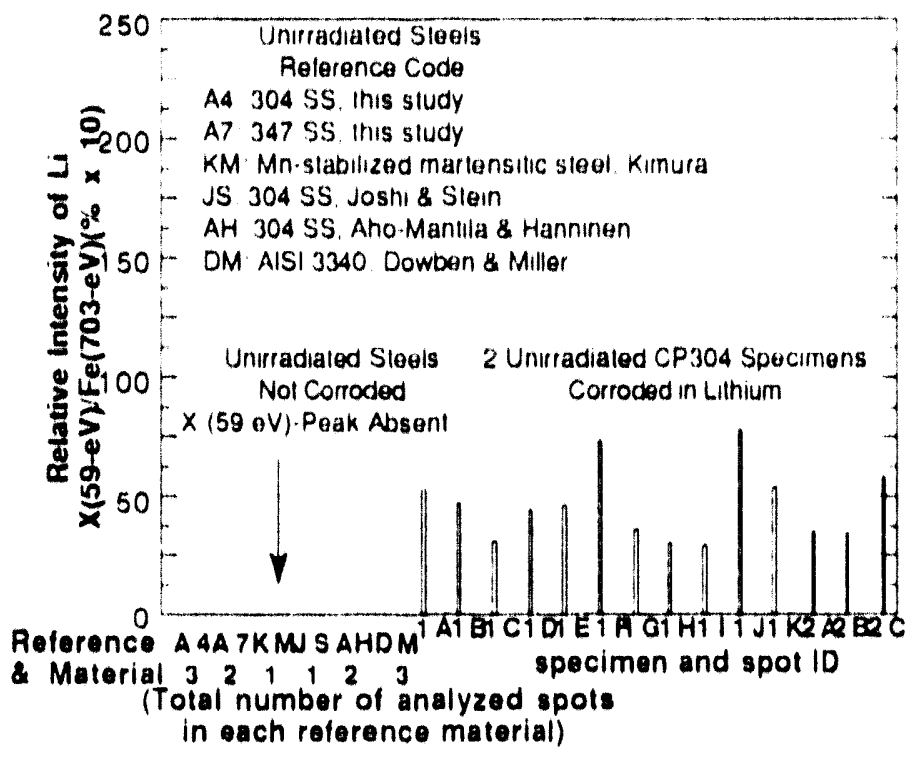

Figure 32. Comparison of intensittes of $=59 \mathrm{eV}$ Auger electron peak obtained from several lypes of nonirradiated steels either as received or corroded in liquid $\mathrm{Li}$ at $600^{\circ} \mathrm{C}$ for $1+4 \mathrm{~h}$ 


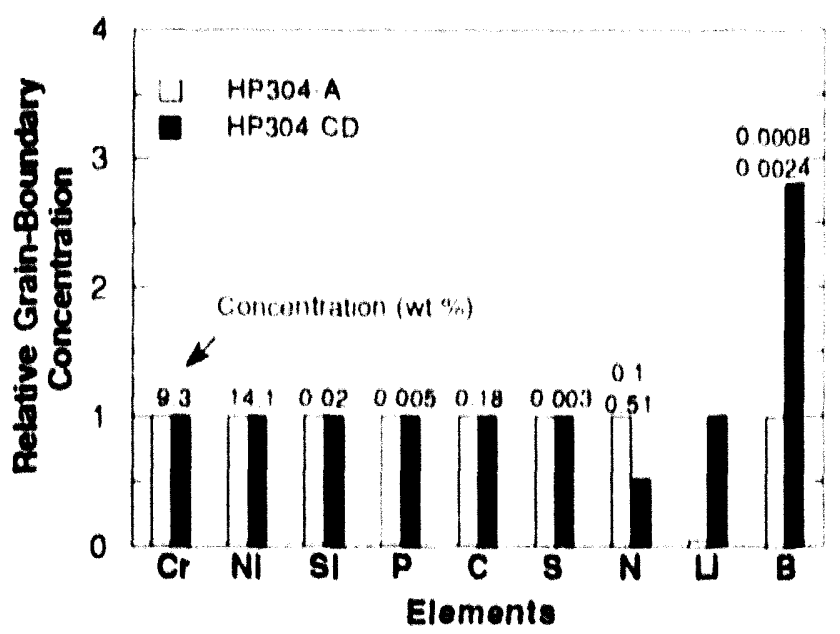

Fygure 33. Relattere grain boundary comeentrallonis of alloying and impuritin elements in III:30.1 A and III's04 (l) absorber lube' speriments irradiated $10-2 \times 10^{21} 11 \mathrm{~cm}^{2}$

\section{Environmentally Assisted Cracking of Ferritic Steels}

Over the past 15 years, the corroston fillgue properlles of low alloy steels in LWR primary system waler chemistrles have bech studled exlensively. 7073 Much less information is avallable on SCC of these mallerials.74-78 Because 11 is clear llat very high CGRs can occur in some materlals under some comblnatlons of loading and environment. the objective of the current work is to befler define the circumistances that can produce SCC In these steels.

\subsection{Technical Progress (J. Y. Park)}

Fracture mechantes CGR tests have continued on IT compact tenston specimens from low and medlum sulfur content heats $(0.004$ and 0.018 wt.\%) of A533 Gir 13 pressure vessel steel and a medlum sulfur conlent $(0.014 \%)$ Alo6 (ir B plplng steel. One of the A533 Gr B specimens was NI Cr plated to betler simulate a clad lerrille sleed vessel, where only the low alloy steel al the cratek surface is exposed to the envirunment. Surface films on the $\mathrm{NI} \mathrm{Cr}$ and on $\mathrm{NI}$ and Au plated specimens lested prevlously are different from those on the nomplated ferritle specimens. Because vittially all existing data have been obtained on specimens withoul claddlug. It is important to verily thall those results were not unduly affected by the character of the surface film.

CGR tests were conducted on a set of three carbon steel specimens INos. CIW7 03. 02C 14, and CTJ7-011 at a higher load rallo, 1.e., $R=0.9$. The composition of the steels was given in the previous report.70 Specimens C'TW7-03 and $02 \mathrm{C}-14$ were prepared from plates of a low and high sulfur $A 5333$ (ir 13 pressure vessel steels, 1.e., Heats No. A5401. $10.004 \% \mathrm{~S}$ and $0.005 \% \mathrm{P})$ and $\mathrm{A} 1195.1(0.018 \% \mathrm{~S}$ and $0.012 \% \mathrm{P}$. respectlvely, and specimen CTJ7-01 was from a Al06 Cir B plping steel, l.e. Heat No. J7201 $10.014 \%$ S and $0.014 \%$ P). Specimen 02C 14 was plated with NI $\mathrm{Cr}$ to simulate austentic SS cladding on a reactor pressure vessel and hence, to determine the validity of using data obtalned from 


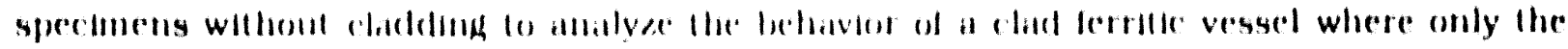

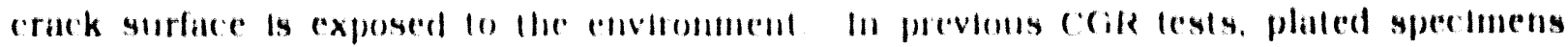

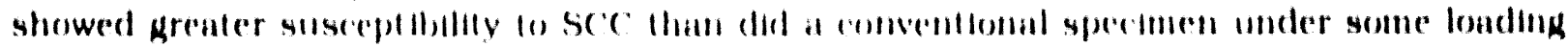
rondilluns ${ }^{\text {so }}$

Tests were performed in delombed walle al 289 (: inder a ryelle load lsawtooth wave

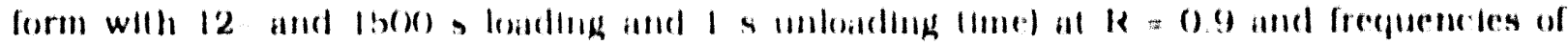

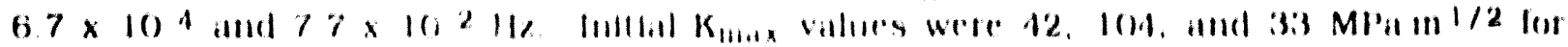

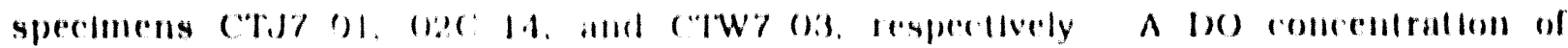

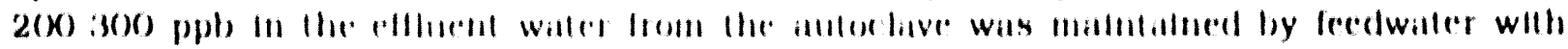

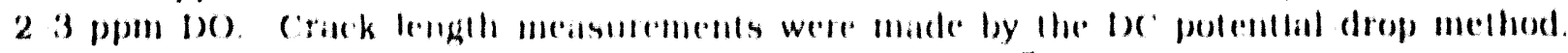

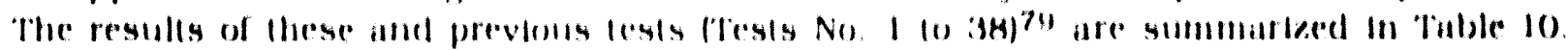
crack growth occurred over a lathe of values from $4.4 \times 10101645 \times 10^{\mathrm{H}} \mathrm{m} / \mathrm{s} /$ for specimen 026: 1.1, whereas no apprectable cratk growlh was observed for nonplated

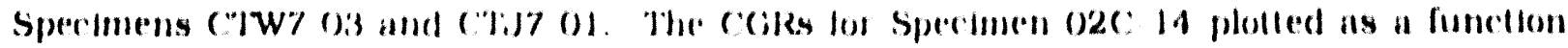

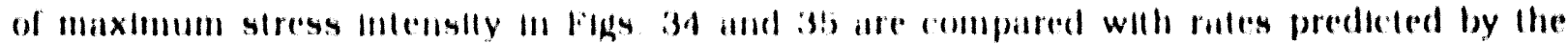

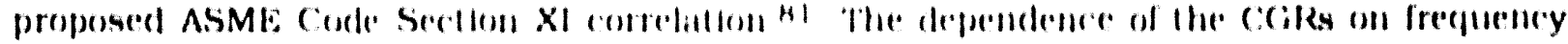

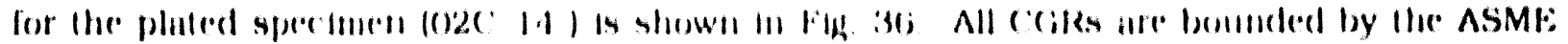

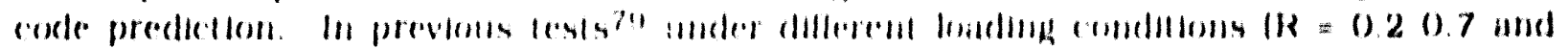

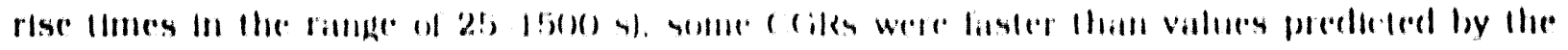
ASME: correlinllon

\section{Summary of Results}

\subsection{Fatigue of Ferritic Piping and Pressure Vessel Stoels}

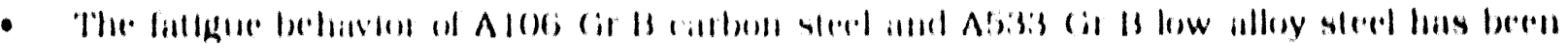

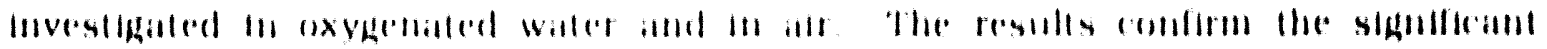

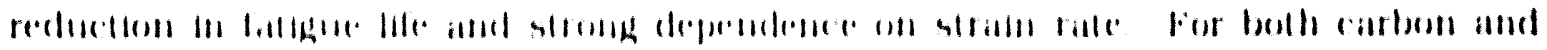

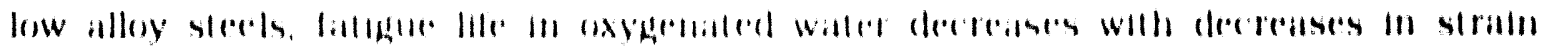

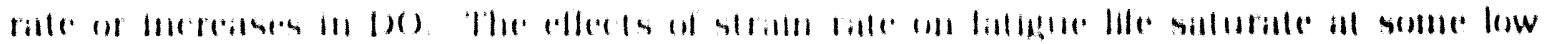

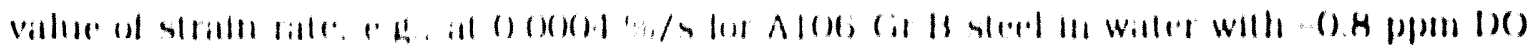

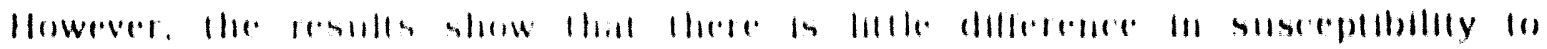

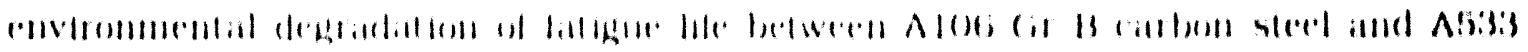

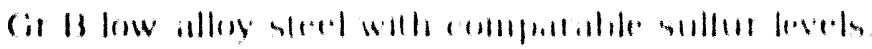

\subsection{Environmentally Assisted Cracking of Cast SS}

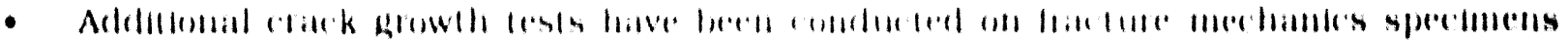

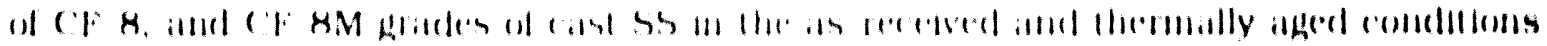

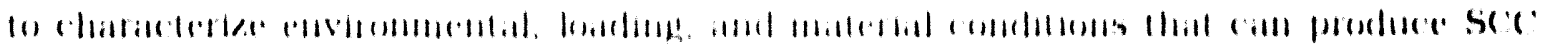

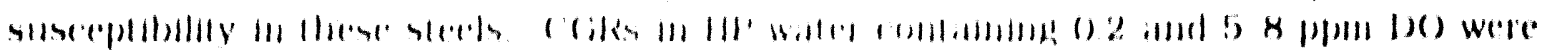

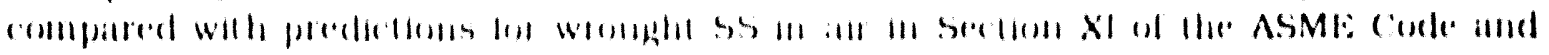

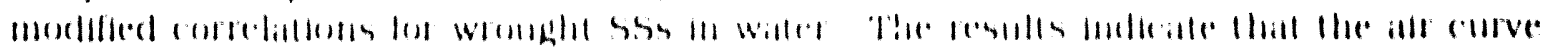

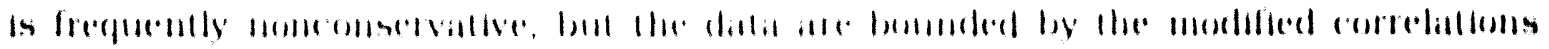

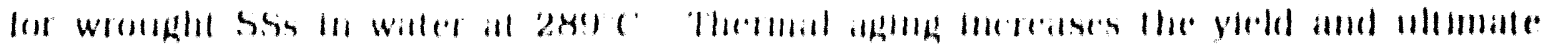

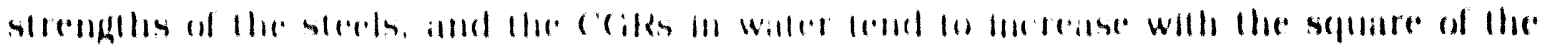
ylelle sliciss. 


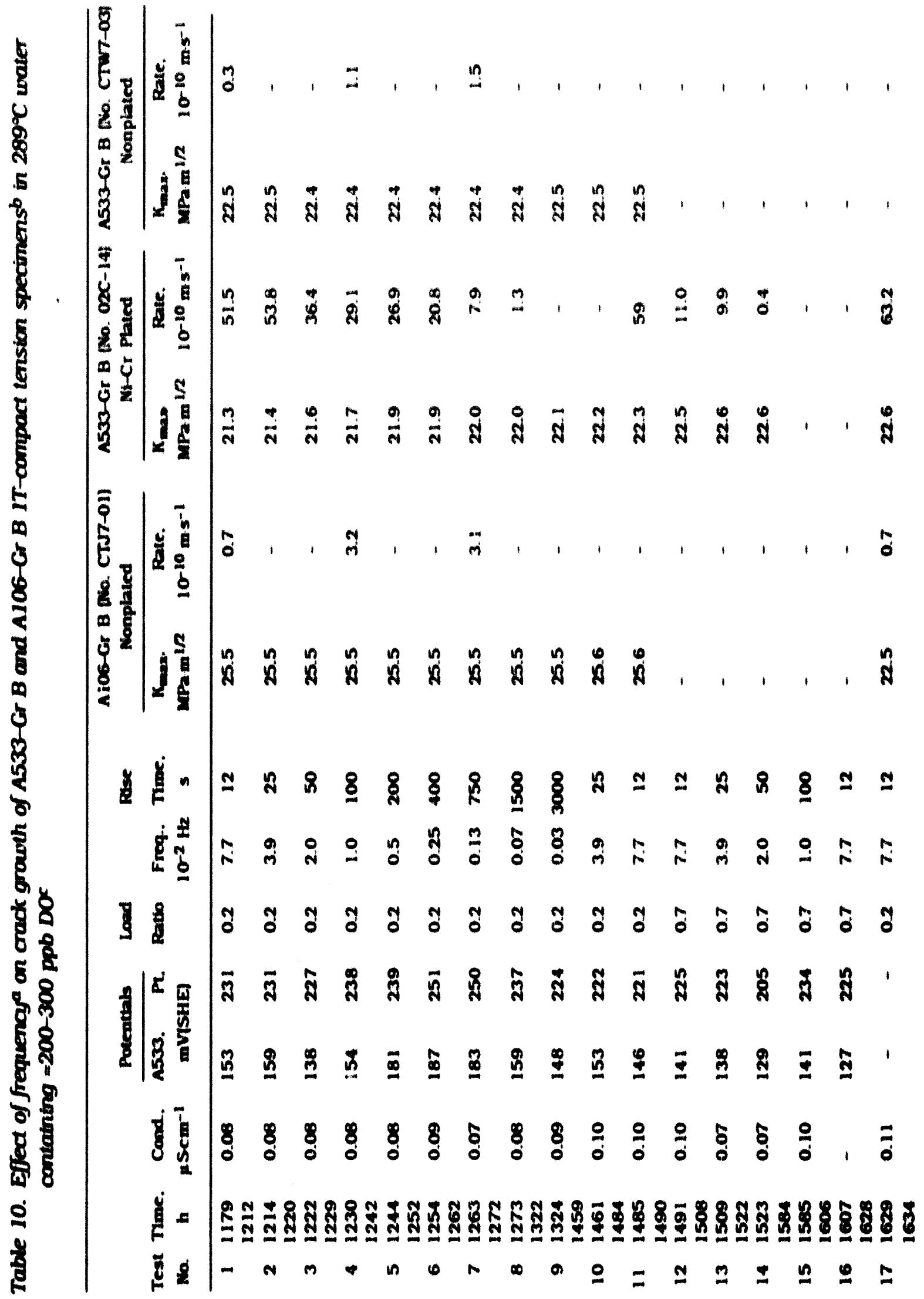




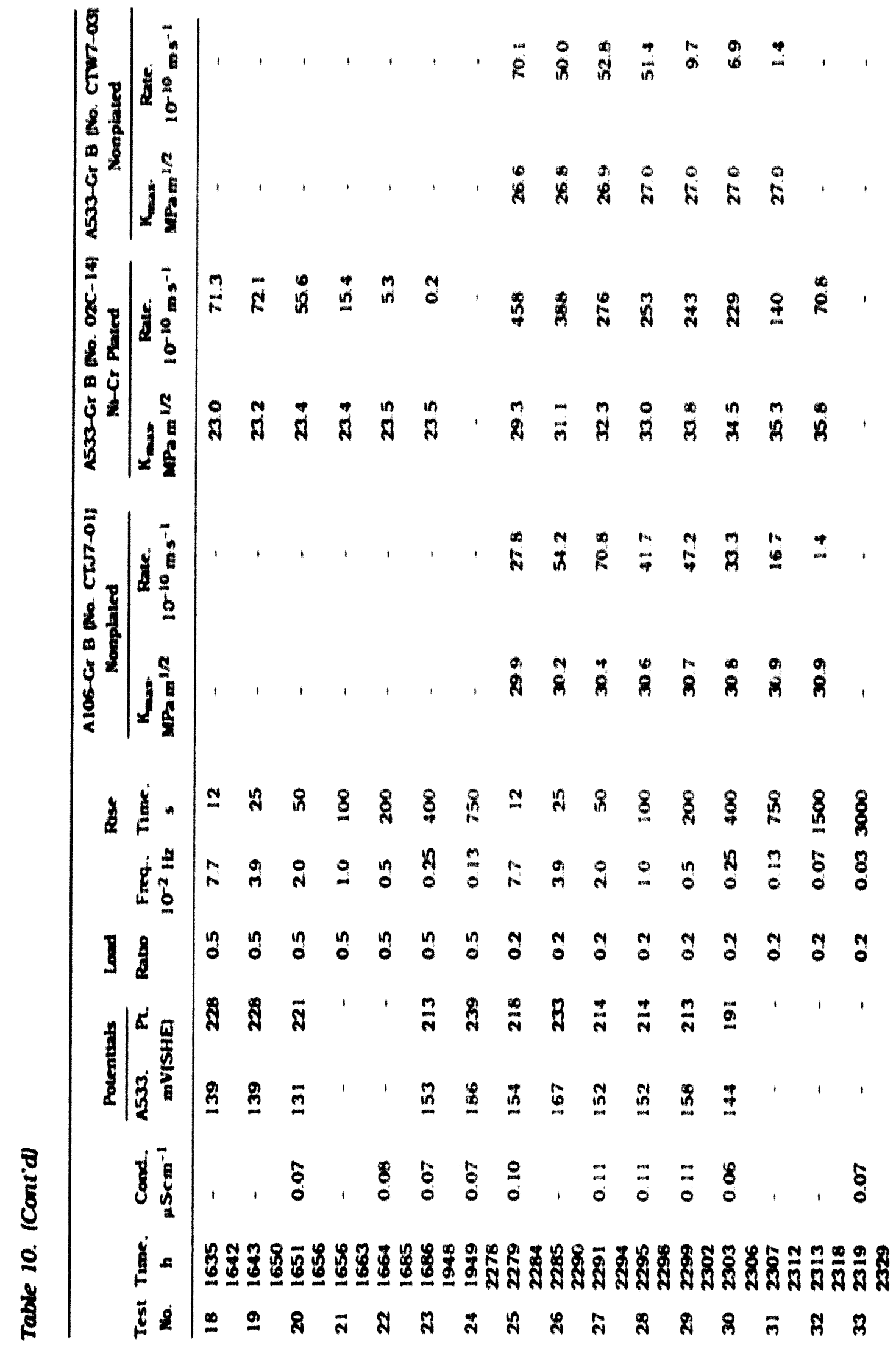




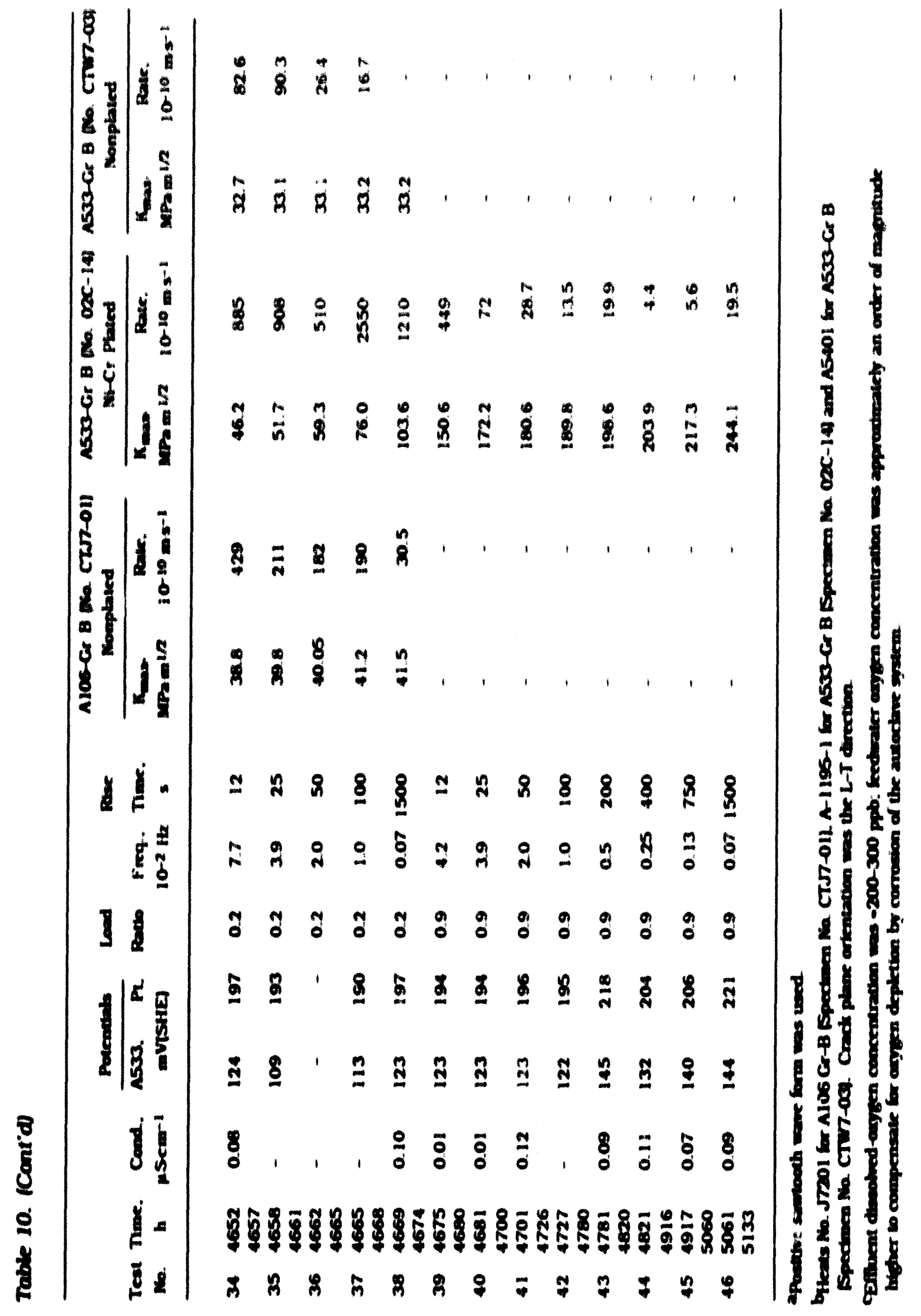



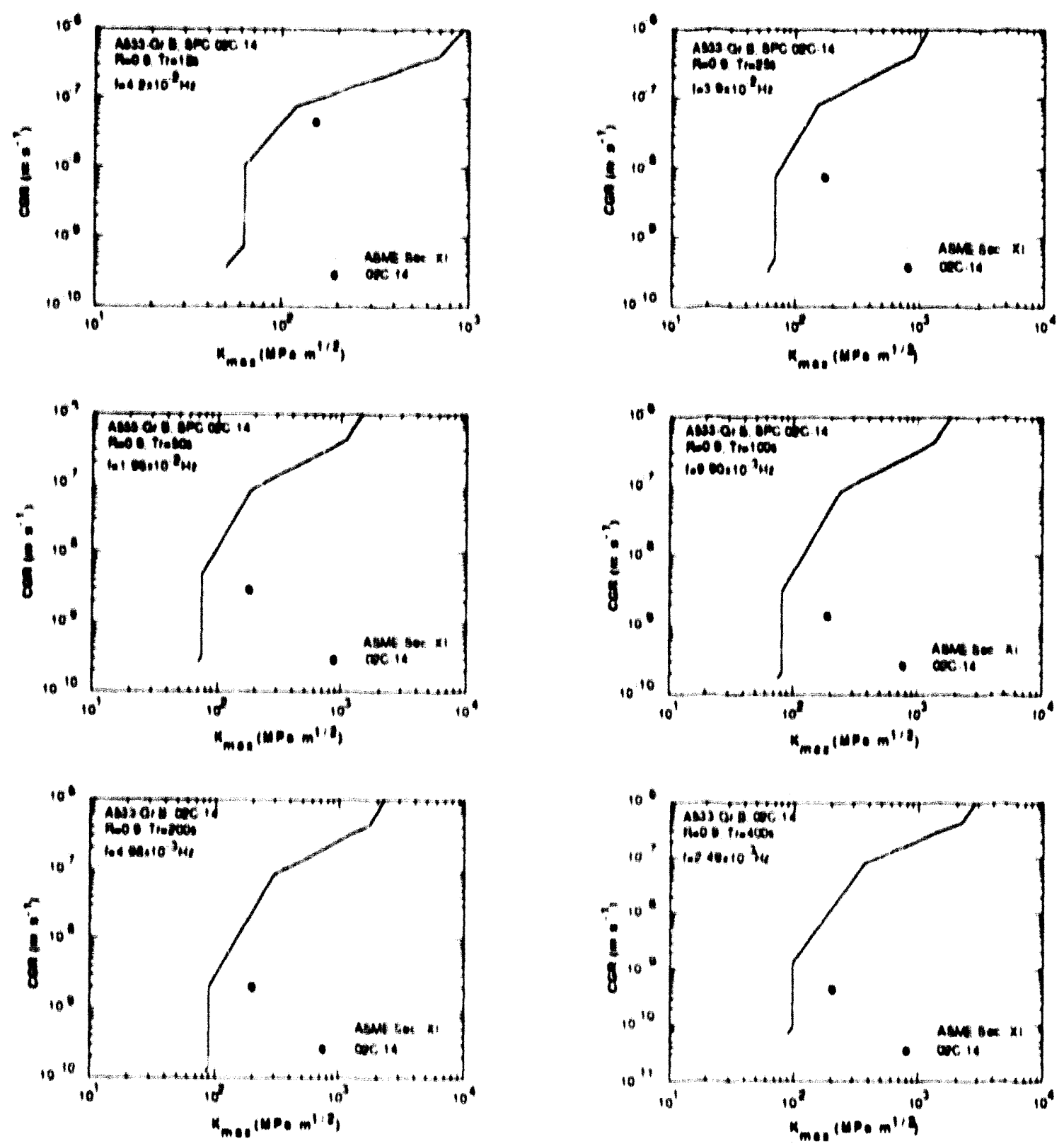

Fuure 34. Crack groulh rates us. maximum stress intensily for $\mathrm{Cr}$ Ni plated A533-

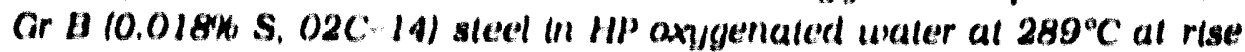
times of 12 t200 s at $R=0.9$ 

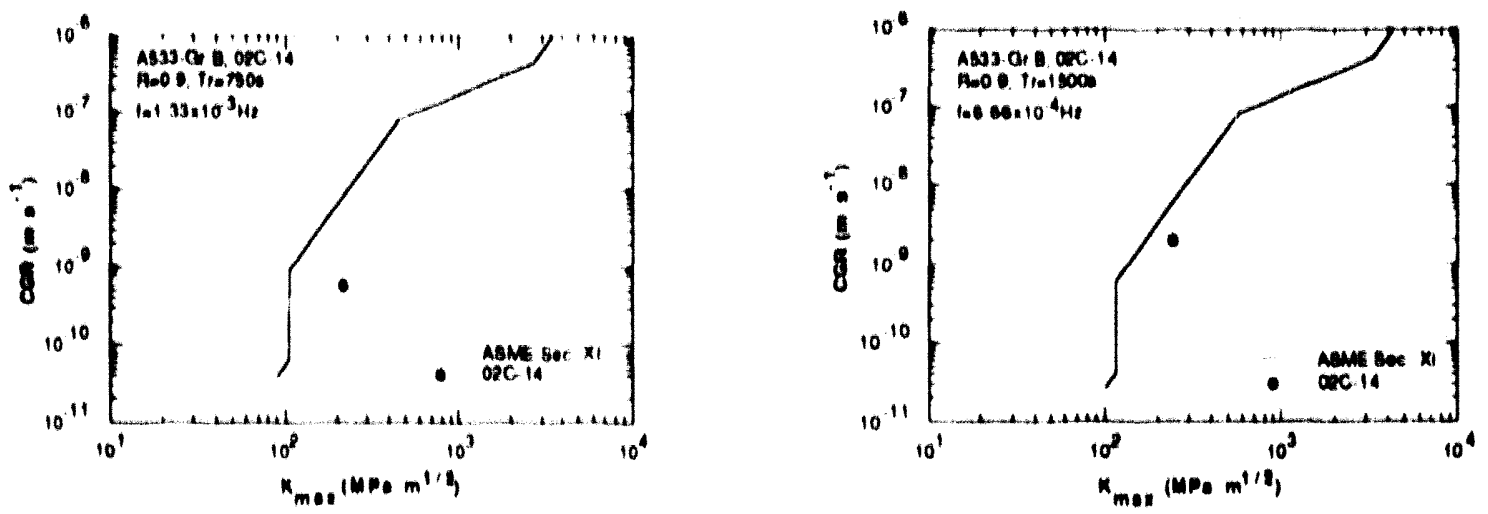

Mygure 35. Crack growth rates us. Inu unum stress intensily. for Cr-NI plated A533Gr $B\left(0.018 \%\right.$ S. $02 \mathrm{C}$ 14) steel in HP oxygenated water at $289^{\circ} \mathrm{C}$ at rtse limes of 75 and 1500 s at $R=0.9$

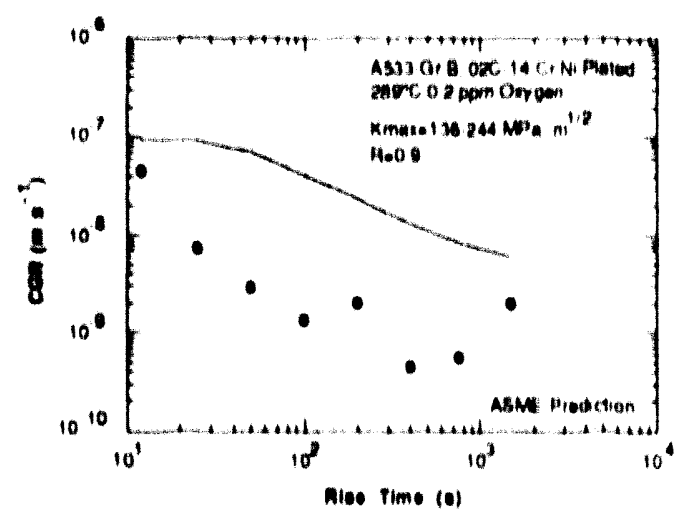

Fyure 36. Crack growth rates us. rise time for $\mathrm{Cr}-\mathrm{N}$ plated A533-Cr B steel $(0.018 \%$ S) at $R=0.9 \mathrm{in}$ $H \mathrm{H}$ oxygenaled water al $289^{\circ} \mathrm{C}$

\subsection{Irradiaflon-Assisted Stress Corrosion Cracking of Typo 304 SS}

- SSRT tests and grain boundary analysis by AES were conducted on high and commerclal purlly (IIP and CP Type 304 SS specimens from Irradiated BWR components. Contrary to previous bellefs, susceptibility to IGSCC could not be correlated wilh radiatlon-Induced segregation (IRIS) of Impuritles such as SI, P, C, or S, but a correlation was obtained with gralin-boundary $\mathrm{Cr}$ concentration. Indicating a role of $\mathrm{Cr}$ depletion. However, graln boundary concentrallons of $\mathrm{Cr}$ determined from presently avallable FEG STEM-EDS and AES techniques are not accurate enough to clartsy the importance of the role of $\mathrm{Cr}$ depletion.

- Grain-boundary analysls was conducted on BWR neutron absorber tubes that were fabricated from two HP heals of Type 304 SS that had virtually identlcal chemical compositions and that were Irradialed to similar fluence level but exhlbited a significant difference in susceptibllity to IGSCC during SSRT tests. Grain-boundary concentrations of $\mathrm{Cr}, \mathrm{NI}, \mathrm{SI}, \mathrm{P}, \mathrm{S}$, and $\mathrm{C}$ of the resistant and susceptlble heats were virtually Identical. However, graln boundaries of the resistant materlal contalned a lower concentration of $N$ aisd higher concentrations of $B$ and $L$ than those of the susceptible material. 
- Boron is known to undergo thermal segregation to grain boundaries in austenitic SSs. Therefore, grain-boundary concentrations of $B$, and hence $L$, could be influenced strongly by thermomechanical processes even if core-internal components are fabricated from the same starting material. In slow cooling of thicker sections (e.g.. BWR top gulde), thermal segregation of $B$, and hence $L I$, is likely to be more pronounced. This will be conducive to the suppression of IASCC under conditions of similar thermal sensitization (1.e., $\mathrm{Cr}$ depletion).

- The present study indicates that a synergism between grain-boundary segregation of $\mathrm{N}$ and $B$ impurities and transmutation by thermal neutrons to $H$ and $L 1$, respectively, ("GST" synergism) plays an important role in IASCC. However, the relative importance of the roles of grain-boundary $\mathrm{Cr}$ depletion and the "GST" synergism is not clear.

\subsection{Environmentally Assisted Cracking of Ferritic Steels}

- Additional fracture-mechanics CGR tests have been performed on nonplated specimens of A106-Gr B and A533-Gr B steel and on a specimen of A533-Gr B plated with Ni-Cr. The effect of frequency on CGR was determined at a load ratio of 0.9 in HP oxygenated $(\approx 200 \mathrm{ppb})$ water at $289^{\circ} \mathrm{C}$. The CGRs for the $\mathrm{Ni-Cr}$-plated A533-Gr B specimen were compared with predicted values from new correlations proposed for inclusion in Section XI of the ASME Boller and Pressure Vessel Code. The observed CGRs were adequately bounded by the proposed ASME Section XI correlations.

\section{Acknowledgments}

W. F. Burke, G. Dragel, D. R. Perkins, D. A. Donahue, and J. C. Tezak contributed to the experimental effort in this program. The BWR components were obtained through the kind assistance of Dr. A. J. Jacobs of General Electric Company. This work was part of a program entitled "Environmentally Assisted Cracking in LWR Systems," sponsored by the Office of Nuclear Regulatory Research, U.S. Nuclear Regulatory Commission, under FIN Number A22 12; Program Manager: Dr. J. Muscara.

\section{References}

1. K. IIda, A Review of Fatigue Fallures in LWR Plants in Japan, Nucl. Eng. Des, 138, 297-j12 (1992).

2. Criteria of Section III of the ASME Boiler and Pressure Vessel Code for Nuclear Vessels, The American Society of Mechanical Engineers, United Engineering Center, New York, Library of Congress Catalog No. 56-3934 (1989).

3. Tentative Structural Design Basis for Reactor Pressure Vessels and Directly Associated Components (Pressurized, Water Cooled Systems), PB 151987, U.S. Department of Commerce, Office of Technical Service, 1 Dec. 1958 Revision.

4. D. A. Hale, S. A. Wilson, E. Kiss, and A. J. Glanuzzi, Low Cycle Fatigue Evaluation of Primary Piping Materials in a BWR Environment. GEAP-20244, U.S. Nuclear Regulatory Commission (Sept. 1977). 
5. D. A. Hale, S. A. Wilson, J. N. Kass, and E. Kiss, Low Cycle Fatigue Behavior of Commercial Piping Materials in a BWR Environment, J. Eng. Mater. Technol. 103. 15-25 (1981).

6. S. Ranganath, J. N. Kass, and J. D. Heald, "Fatıgue Behavior of Carbon Steel Components in High-Temperature Water Environments," Low-Cycle Fatigue and Life Prediction, ASTM STP 770, C. Amzallag, B. N. Leis, and P. Rabbe, eds., American Society for Testing and Materlals, Philadelphia, PA, pp. 436-459 (1982).

7. J. B. Terrell, Fattgue Life Characterization of Smooth and Notched Piping Steel Specimens in $288^{\circ} \mathrm{C}$ Air Environments, NUREG/CR-5013, MEA-2232 (May 1988).

8. J. B. Terrell. Effect of Cyclic Frequency on the Fatigue Lile of ASME SA-106-B Piping Steel in PWR Environments, J. Mater. Eng. 10,193-203 (1988).

9. P. D. Hicks, in Environmentally Assisted Cracking in Light Water Reactors: Semiannual Report October 1990-March 1991, NUREG/CR-4667 Vol. 12, ANL-91/24, pp. 318 (Aug. 1991).

10. P. D. Hicks and W. J. Shack, Fatlgue of Ferritic Steels, in Environmentally Assisted Cracking in Light Water Reactors, Semiannual Report. April-September 1991 . NUREG/CR-4667 Vol. 13. ANL-92/6, pp. 3-8 (March 1992).

11. M. Higuchi and K. Ilda, Fatigue Strength Correction Factors for Carbon and LowAlloy Steels in Oxygen-Containing High-Temperature Water, Nucl. Eng. Des. 129. 293-306 (1991).

12. K. IIda, H. Kobayashi, and M. Higuchi, Predictive Method of Low Cycle Fatigue Life of Carbon and Low Alloy Steels in High Temperalure Water Environments, NUREG/CP0067, MEA-2090, Vol. 2 (April 1986).

13. N. Nagata, S. Sato, and Y. Katada, Low-Cycle Fatigue Behavior of Low-Alloy Steels in High-Temperature Pressurtzed Water. Transactions of the 10th International Conf. on Structural Mechanics in Reactor Technology. Vol. F. A. H. Hadjian, ed., American Association for Structural Mechanics in Reactor Technology, Anaheim, CA (1989).

14. S. Majumdar, O. K. Chopra, and W. J. Shack, Interim Faltgue Design Curves for Carbon, Low-Alloy, and Austenitic Stainless Steels in LWR Environments, NUREG/CR5999, ANL-93/3 (Aprll 1993).

15. T. A. Prater and L. F. Coffin. The Use of Notched Compact-Type Specimens for Crack Inttiation Design Rules in High-Temperature Water Environments, Corrosion Fatigue: Mechanics Metallurgy, Electrochemistry, and Engineering, ASTM STP 801, T. W. Crooker and B. N. Leis, eds., American Society for Testing and Materials, Philadelphia, pp. 423-444 (1983).

16. T. A. Prater and L. F. Coffin, Notch Fatigue Crack Initiation in High Temperature Water Environments: Experiments and Life Prediclion. J. of Pressure Vessel Technol., Trans. ASME, 109, 124-134 (1987).

17. O. K. Chopra and G. Ayrault, Aging Degradation of Cast Stainless Steel: Status and Program, Nucl. Eng. Des. 86, 69-77 (1985).

18. H. M. Chung and O. K. Chopra, Microstructures of Cast-Duplex Stainless Steels After Long-Term Aging, in Proc. of the 2nd Int. Symp. on Environmental Degradation of Materials in Nuclear Power Systems - Water Reactors, Monterey, CA. The American Nuclear Soclety, La Grange Park, IL, pp. 287-292 (1986). 
19. H. M. Chung and O. K. Chopra, Long Term Aging Embrilltement of Cast Austenllic Stainless Steels. Mechanisms and Kinetics, In Propertles of Stainless Steels in Elevated Temperature Service, M. Prager, ed., MPC-Vol. 26. PVP Vol. 132. American Society of Mechanical Englneers, New York, pp. 17-34 (1988).

20. H. M. Chung and O. K. Chopra. Kinetics And Mechanisms of Thermal Aging Embrittement of Duplex Stainless Steels, in Proc. 3rd Int. Symp. on Environmental Degradation of Materials in Nuclear Power Systems - Water Reactors. Traverse Cily, MI, G. J. Theus and J. R. Weeks, eds., The Mctallurgkeal Society, pp. 359-370 (1988).

21. H. M. Chung. Thermal Aging of Decommisstoned Reactor Cast Stainless Steel Components and Methodology for L/fe Irediction. Proc. 1989 ASME Pressure Vessel and Piping Conf., Honolulu, Hawail, 'T. V. Narayana, et. al., eds., PVP Vol. 171, pp. $111-115$ (1989).

22. H. M. Chung. Sptnodal like Decomposition of Austentle in Long Term Aged Duplex Stainless Steel, Physlcal Metallurgy of Controlled Expanslon lnvar -Type Alloys, K. C. Russell and D. F. Smlth, eds.. The Minerals, Metals, and Materlals Society, Warrendale, PA, pp. 129-141 (1990).

23. H. M. Chung and T. R. Leax, Embrillement of Laboratory and Reactor-Aged CF-3, CF.8, and CF.8M Duplex Stainless Stecls, Mater. Scl. and Technol. 6, 249-262 (1990).

24. H. M. Chung and O. K. Chopra, Accelerated Aging Embrillement of Cast Duplex Statnless Steel. Activation Encrgy for Extrapolation. Proc. 4th Int. Symp, on Environmental Degradation of Materials in Nuclear Power Systems Water Reactors, D. Cubicclotli, ed., National Assoctallon of Corrosion Engineers, Houston. pp. 3-47 to 3.65 (1990).

25. H. M. Chung, Evaluation and Diagnosis of Aging of Cast Stainless Steel Components, Proc. ASME Pressure Vessel and Piplug Conl.. PVP Vol. 208. American Soclety of Mechanical Englneers, New York, pp. 121 136 (1991).

26. H. M. Chung. Aging and Life Prediction of Cast Duplex Stainless Steel Components, Int. J. Pres. Ves. \& Plpling 50, 179 213 (1992).

27. O. K. Chopra and H. M. Chung, Aging of Cast Duplex Stainless Sleels in LWR Systems, Nucl. Eng. Des. 89, 305.318 (1985).

28. O. K. Chopra and H. M. Chung. Elferts of Lou Temperature Aging on the Mechantical Propertles of Cast Stainless Steels, in Properties of Stalnless Steels in Elevated Temperature Servlce, M. Prager, ed., MPC Vol. 26. PVI Vol. 132. Amerlcan Soclety of Mechanical Engineers, New York, Pp. 79105 (1988).

29. O. K. Chopra and H. M. Chung, Aging Degradation of Cast Stainless Steels: Elfects on Mechantcal Properties, In Proc. 3rd Int. Symp. on Envirommental Degradation of Materials in Nuclear Power Systems Waler Reactors, Traverse Clly, MI. G. J. Theus and J. R. Weeks, eds., The Melallurgical Soriely, pp. 737748 (19)88).

30. O. K. Chopra and H. M. Chung, Embritlememl of cast Statnless Sterels in LWR Systems, Proc. 15th MPA Seminar on Silfely and Reliablilly of Mant lechnology, Vol. 1, pp. $13.1 \cdot 13.23(1989)$. 
31. O. K. Chopra, Thermal Aging of Cast Stainless Steels: Mechanisms and Predictions, Fatigue, Degradation, and Fractures, W. H. Bamford, C. Becht IV, S. Bhandarl, J. D. Gilman, L. A. James, and M. Prager, eds., PVP Vol. 195, The American Soclety of Mechanical Engineers, New York, pp. 193-214 (1990).

32. O. K. Chopra, Thermal Aging of Cast Stainless Steels in LWR Systems: Estimation of Mechantcal-Properties, Nuclear Plant Systems/Components Aging Management and Life Extension, American Soclety of Mechanical Engineers, PVP Vol. 228, pp. 79-92 (1992).

33. O. K. Chopra, Prediction of Aging Degradation of Cast Stainless Steel Components in LWR Systems, in Proc. Aging Research Information Conf., NUREG/CP-0122 Vol. 2. pp. 324-340 (1992).

34. O. K. Chopra and W. J. Shack, Evaluation of Aging Degradation of Structural Components, in Proc. Aging Research Information Conf., NUREG/CP-0122 Vol. 2. pp. 369-386 (1992).

35. O. K. Chopra, Long-Term Embritlement of Cast Duplex Stainless Steels in LWR Systems: Semtannual Report. October 1990 - March 1991, NUREG/CR-4744 Vol. 6. No 1, ANL-91/22 (Aug. 1992).

36. O. K. Chopra, Long-Term Embrilllement of Cast Duplex Stainless Steels in LWR Systems: Semiannual Report, Aprll - Seplember 1991, NUREG/CR-4744 Vol. 5, No 2, ANL-92/32 (Nov. 1992).

37. O. K. Chopra. Long-Term Embritlement of Cast Duplex Stainless Steels in LWR Systems: Semlannual Report, October 1991 - March 1992, NUREG/CR-4744 Vol. 7. No 1, ANL-92/42 (May 1993).

38. W. E. Ruther, O. K. Chopra, and T. F. Kassner, in Environmentally Assisted Cracking in Light Water Reactors: Semiannual Report, Aprll - September 1992, NUREG/CR-4667 Vol. 15. ANL-93/2, pp. 21-28 (June 1993).

39. W. E. Ruther, J. Y. Park, T. F. Kassner, and W. K. Soppet, in Environmentally Assisted Cracking in Light Water Reactors: Semiannual Report, October 1988 - March 1980 NUREG/CR-4667 Vol. 8, ANL 90/4, pp. 2-5 (June 1990).

40. J. Y. Park and W. J. Shack, In Environmentally Assisted Cracking in Light Water Reactors: Semiannual Report, April 1989 - September 1989, NUREG/CR-4667 Vol. 9. ANL-90/48, pp. 3-6 (March 1991).

41. W. J. Shack, in Environmentally Assisted Cracking in Light Water Reactors: Semiannual Report, October 1990 - March 1991. NUREG/CR-4667 Vol. 12, ANL-91/24. pp. 30-37 (Aug. 1991).

42. A. B. Hull, P. R. Luebbers, M. R. Fox, W. K. Soppet, and T. F. Kassner, Aqueous Stress Corrosion of Candidate Austentlic Stainless Steels for ITER Applications, in Fusion Reactor Materials Semiannual Progress Report for the Perlod Ending March 31, 1992. DOE/ER-0313/12, pp. 225-235 (July 1992).

43. D. M. French, W. K. Soppet, and T. F. Kassner, Aqueous Stress Corroston of Candidate Austenitic Stainless Steels for ITER Applications, in Fusion Reactor Materials Semiannual Progress Report for the Pertod Ending September 30, 1992, DOE/ER0313/13, pp. 276-284 (March 1993). 
44. W. E. Ruther, T. F. Kassner and J. Y. Park, In Environmentally Assisted Cracking in Light Water Reactors: Semiannual Report, October 1991 - March 1992. NUREG/CR4667 Vol. 14, ANL-92/30, pp. 33-42 (Aug. 1992).

45. X. J. Wu, A. K. Koul, and A. S. Krqus\%, A Transgranular Fatigue Crack Growth Model Based on Restricted Slip Reversibllity. Met Trans. 24A, 1373-1380 (1993).

46. J. F. Knott, Fundamentals of Fracture Mechanics, John Wiley \& Sons, New York (1973).

47. J. P. Benson and D. V. Edmonds, Met. Scl. 12, 223-232 (1978).

48. J. Low, U. Wollf, and W Cowden, Electron Mic oscopic Examination of Falled Stainless Steel Fuel Cladding - Dresden Advanced Fuel Assemblles PF. 1 and PR.4. APED-4242. General Electric Co. (May 1963).

49. J. S. Armijo. Elfect of Impurity Addilions on the Intergranular Corrosion of High Purity Fe Cr-Ni Austenllic Alloys, GEAP-5047, General Electric Co. (Oct. 1966).

50. J. S. Armyjo, Grain Boundary Studies of Austentlic Stainless Stcels. GEAP-5503. General Electric Co. (Sept. 1967).

51. J. S. Armijo, Intergranular Corrosion of Nonsensilized Austenilic Stainless Steels, Corrosion 24, 24-30 (1968).

52. R. Duncan, Stainless Steel Failure Investigation Prograin, GEAP-5530, General Electric Co. (Feb. 1968).

53. A. Strasser, J. Santuccl, K. Lindquilst, W. Yarlo, G. Stern, L. Goldstein, and L. Joseph, Evaluation of Slainless Sleel Cladding in LWRs. EPRI NP-2642. Electric Power Research Instllute. Palo Alto, CA (Dee, 1982).

54. F. Garzarolli, D. Alter, and P. Dewes, Deformabilty of Austentlic Stainless Steels and Nt-Base Alloys in the Core of a Boiling and Pressurized Water Reactor, Proc. 2nd Int. Symp. Environmental Degradallon of Materials in Nuclear Power Systems - Water Reactors, Nallonal Associalion of Corrosion Englneers. Houston, pp. 131-138 (1986).

55. F. Garzarolli, D. Alter, P. Dewes, and J. L. Nelson, Deformability of Austentlic Stainless Steels and Nt-Base Alloys in the Core of a Boiling and Pressurized Water Reactor. Proc. 3rd Int. Symp. Environmental Degradalion of Materials in Nuclear Power Systems - Water Reactors, G. J. Theus and J. R. Weeks, eds., The Metallurglcal Soclety. Warrendale, PA, pp. 657 664 (1988).

56. A. J. Jacobs, R. E. Clausing. M. K. Miller, and C. Shepherd. Influence of Grain Boundary Composilton on the IASCC Susceptibilly of Type 348 Stainless Steel. Proc. 4th Int. Symp. Environmental Degradation of Materlals in Nuclear Power Systems Water Reactors, National Assoclation of Corrosion Engineers, Houston, pp. 14-21 to 14-45 (1990).

57. A. J. Jacobs, G. P. Wozaldo, K. Nakata, T. Yoshida, and I. Masaoka, Radiation Effects on the Stress Corrosion and Other Selected Propertles of Type-304 and Type-316 Stainless Steels. Proc. 3rd Int. Symp. Environmental Degradation of Materials in Nuclear Power Systems - Water Reactors ${ }_{2}$ G. J. Theus and J. R. Weeks, eds., The Metallurgical Soclety. Warrendale, PA, pp. pp. 673-681 (1988). 
58. A. J. Jacobs. The Relationship of Grain Boundary Composition in Irradiated Type 304 SS to Neutron Fluence and IASCC, Effects of Radiation on Materlals: 16th Int. Symp., ASTM STP 1175, A. S. Kumar, D. S. Gelles, R. K. Nanstad, and T. A. Little, eds., American Society for Testing and Materlals. Phlladelphia, 1993.

59. H. M. Chung, W. E. Ruther, J. E. Saneckl, A. G. Hins, and T. F. Kassner, Stress Corrosion Cracking Susceptlbilty of Irradlated Type 304 Stainless Steels, Effects of Radiation on Materlals: 16th Int. Symp., ASTM STP 1175, A. S. Kumar, D. S. Gelles, R. K. Nanstad, and T. A. Litlle, eds.. American Soclety for Testing and Materials, Phlladelphla, 1993.

60. H. M. Chung, W. E. Ruther, J. E. Saneck1, and A. G. Hins, In Environmentally Assisted Cracking in Light Water Reactors: Semlannual Report April-September 1992. NUREG/CR-4667, Vol. 15, ANL-93/2, Argonne National Laboratory, pp. 28-60 (June 1993).

61. K. Fukuya, S. Shima, H. Kayano, and M. Narul, Stress Corrosion Cracking and Intergranular Corrosion of Neutron Irradiated Austenttic Steels. J. Nucl. Mater. 181 . 194, 1007-1011 (1992).

62. K. Fukuya, K. Nakata, and A. Horie, An IASCC Study Using High Energy Ion Irradiation, Proc. 5th Int. Symp. Environmental Degradation of Materlals in Nuclear Power Systems - Water Reactors, American Nuclear Society, La Grange Park, IL. pp. 814-820 (1992).

63. J. M. Cookson, R. D. Carter, D. L. Damcolt, M. Atzmon, G. S. Was, and P. L. Andresen, Stress Corrosion Cracking of High Energy Proton.Irradiated Stainless Steels, Ibid.. pp. 806-813.

64. M. Kodama, S. Nishimura, J. Morisawa, S. Shima, S. Suzukl, and M. Yamamoto, Effects of Fluence and Dissolved Oxygen on IASCC in Austenitic Stainless Steels. Proc. 5th Int. Symp. Environmental Degradation of Materlals in Nuclear Power Systems Water Reastors, American Nuclear Soclety, La Grange Park, IL. pp. 948-954 (1992).

65. K. Asano, K. Fukuya, K. Nakata, and K. Kodama, Changes in Grain Boundary Composition by Neutron Irradiation on Austenitic Stainless Steels, Ibld. pp. 838-843.

66. E. A. Kenik, Radiation-Induced Segregation in Irradiated Type 304 Stainless Steels. J. Nucl. Mater. 187 (1992), 239-246.

67. S. M. Bruemmer, B. W. Arey, and L. A. Charlot, Influence of Chromium Depletion on the Intergranular Stress Corrosion Cracking of 304 Stainless Steel. Corrosion 48(1), 42.49 (1992).

68. D. I. R. Norris, C. Baker, and J. M. Titchmarsh. Composilional Profiles at Grain Boundarles in $20 \% \mathrm{Cr} / 25 \% \mathrm{Ni} / \mathrm{Nb}$ Stainless Steel. Proc. Symp. on Radiation-Induced Sensitization of Stainless Steels, D. I. R. Norris, ed., Central Electricity Generating Board, Berkeley, England, pp. 86-98 (1987).

69. J. M. Titchmarsh and I. A. Vatter, Measurement of Radiation-Induced Segregation Profles by High Spatial Resolution Electron Microscopy. Ibld., pp. 74-85.

70. P. D. Hicks and F. P. A. Robinson, Fattgue Crack Growth Rates in a Pressure Vessel Steel under Various Conditions of Loading and the Environment, Met. Trans. 17A. 1837-1849 (1986). 
71. Proc. of Int. Atomic Energy Agency Spectalists' Meeting on Subcriltcal Crack Growth, NUREG/CP-0044, MEA-2014, Vols. 1 \& 2 (May 1983).

72. Proc. of 2nd Int. Atomic Energy Agency Spectalists' Meeting on Subcritlcal Crack Growth, NUREG/CP-0067, MEA-2090, Vols. 1 \& 2 (April 1986).

73. Proc. of 3rd Int. Atomic Energy Agency Spectaltsts' Meeting on Subcrittcal Crack Growth, NUREG/CP.0112. Vols. 1 \& 2 (Aug. 1990).

74. T. A. Prater, W. R. Callin, and L. F. Coffin, Surface Crack Growth Behavlor of Structural Metals in High Temperature Water Environments, J. Eng. Mater. Technol. 108, 2-9 (1986).

75. M. O. Speidel and R. M. MagdowskI, Stress Corrosion Cracking of Nuclear Reactor Pressure Vessel Steel in Water: Crack Intliation versus Crack Growlh. NACE Corrosion 88. Paper No. 283. St, Louls, MO, (Mar. 1988).

76. D. A. Hale. The Elfect of BWR Startup Envtronments on Crack Growth in Structural Alloys, J. Eng. Mater. Technol. 108, 44-49 (1986).

77. F. P. Ford and P. L. Andresen, Stress Corroston Cracking of Lou-Alloy Pressure Vessel Steels in $288^{\circ} \mathrm{C}$ Water, in Proc. 3rd Int. Atomlc Energy Agency Speciallsts' Meeling on Subcritlcal Crack. Growth, NUREG/CP-0112, Vol. 1. pp. 37-56 (Aug. 1990).

78. P. M. Scott and D. R. Tice, Stress Corroston in Low-Alloy Steels. Nucl. Eng. Des. 118. 399-413 (1990).

79. J. Y. Park, in Environmentally Assisted Cracking in Light Water Reactors: Semtannual Report April -September 1992. NUREG/CR-4667 Vol. 15. ANL-93/2, pp. 13-20 (June 1993).

80. J. Y. Park, In Environmentally Assisted Cracking in Light Water Reactors: Semtanmual Report October 1991-March 1992, NUREG/CR-4667 Vol. 14, ANL 92/30, pp. 1418 (Aug. 1992).

81. E. D. Eason, EDEAC Status; Analysis Procedures for da/dN and $S-N$ Data, In Technical Iniormation from Workshop Cyclic Life and Environmental Efferta in Nuclear Applications, Vol. 2, Clearwater Beach, FL. Pressure Vessel Research Committee and Welding Research Councll (Jan. 20-21, 1992). 


\section{Distrlbution for NUREQ/CR-4667, Vol. 16 (ANL-93/27)}

Internal

W. J. Shack (45)

TIS Files

External

NRC for distribution per R5

Libraries

ANL-E

ANL-W

Manager, Chicago Fleld Olfice, DOE

Energy Technology Divis ion Review Commiltee:

H. K. Birnbaum, Universily of Illinols, Urbana

R. C. Buchanan, Universlty of Cincinnatl, Cincinnatl

M. S. Dresselhaus, Massachusells Instllute of Technology, Cambridge, MA

B. G. Jones, University of Illinois, Urbana

C.- Y. LI, Cornell University, Ithaca, NY

S. N. Llu, Fremonl, CA

R. E. Smilh. Engineering Applied Sclences, Inc., Trafford, PA

P. L. Andresen, General Electrlc Corporate Research and Development. Schenectady, NY

R. G, Ballinger, Massachusetts Institute of Technology, Cambridge, MA

W. H. Bamford, Structural Materials Engineering. Westinghouse Electric Corp., Plltsburgh

S. M. Bruemmer, Battelle Pacific Northwest Laboratory

G. Cragnolino, Southwest Research Inst., San Antonto, TX

W. H. Cullen, Materials Engineering Assoc., Inc., Lanham, MD

R. Duncan, ABB CE Nuclear Power, WIndsor, CT

E. D. Eason, Modeling and Computing Services, Newark, CA

M. Fox, APTECH, Tucson, AZ

D. G. Franklin, Betlis Atomic Power Laboratory

Y. S. Garud, S. Levy, Inc., Campbell, CA

F. Garzarolli, KWU, Erlangen, Germany

J. Gllman, Electric Power Research Inst., Palo Alto, CA

B. M. Gordon, General Electric Co., San Jose, CA

S. J. Green, Electric Power Research Instltute, Palo Alto, CA

J. W. Halley, U. Minnesota, Minneapolis

H. E. Hanninen, Technical Research Centre of Finland, Espoo

D. Harrison, USDOE, Germantown, MD 
J. Hickling. CML Capcis March LId. Erlangen Tennonlohe, Germany

C. Holmann, ABU CE Nuclear Power, WIndsor, CT

M. E. Indig, General Fiectric Co., Plensanion, CA

H. S. Isaacs, Brookhaven Natlonal Laboralory

A. Jacobs, General Electric Co., San Juse, CA

L. James. Betlis Alomic Power Laboralory

C. Jansson, Vallenfall Energisystem. Vallinglby, Sweden

R. H. Jones. Batlelle Pacilic Northwesl Luboratory

T. Karlsen, OECD Halden Reactor Project, Halden, Norwuy

J. N. Kass, Lawrence L.Ivermore Nallonal Labornlory

C. KIm, Westinghouse Electric Corp., PIlisburgh

L. L.Jungberg. ASEA ATOM, Visterus, Sweden

C. D. Lundin, U. Tennessere, Knoxville

D. 1). Macdonald, Pennsylvaila Slale Universily, Unlverslly Park

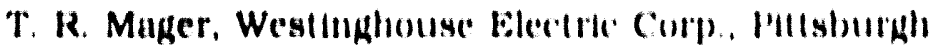

H. Metha, Cieneral Electrie Co., Sill Juse, CA

D. Morgan, Pennsylvanla l'ower and l.jplil co., Allentown, in

J. L. Nelson, Electric Power Reseatreh linst, Palo Allo, CA

M. Pruger, Malerials Propertles Council, New York, NY

S. Rnnganalh, General Electric Co., Sin, Juse, CA

P. M. Scoll, Framatome, Paris, france

C. Shepherd, AEA Techmolugy Harwell Labs, IIdeol, Oxun, UK

S. Smbalowsku, Ohlu Slille Unlverslly, Columbur

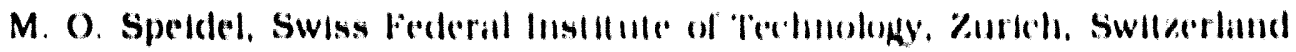

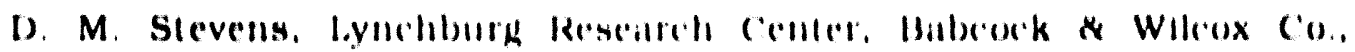
Lynchburs, VA

W. A. Van Der Sluys, Researeh \& Developulnenl Divislon, Babrock \& Wilcox Co., Allance, OHI

J. C. Van Duysen. Electriclle de Frillee Research and Development Centre de Renardieres, Moret Sur Lelang. France

E. Venerus, Knolls Alomile Power Laburalory

J. R. Weeks. Brookhaven Nallomial laiborallory

D. Winkel, Teleco Oil Field Servieres, Merklent, ("l'

S. Yukewi, Bonlder, $\mathrm{CO}$ 

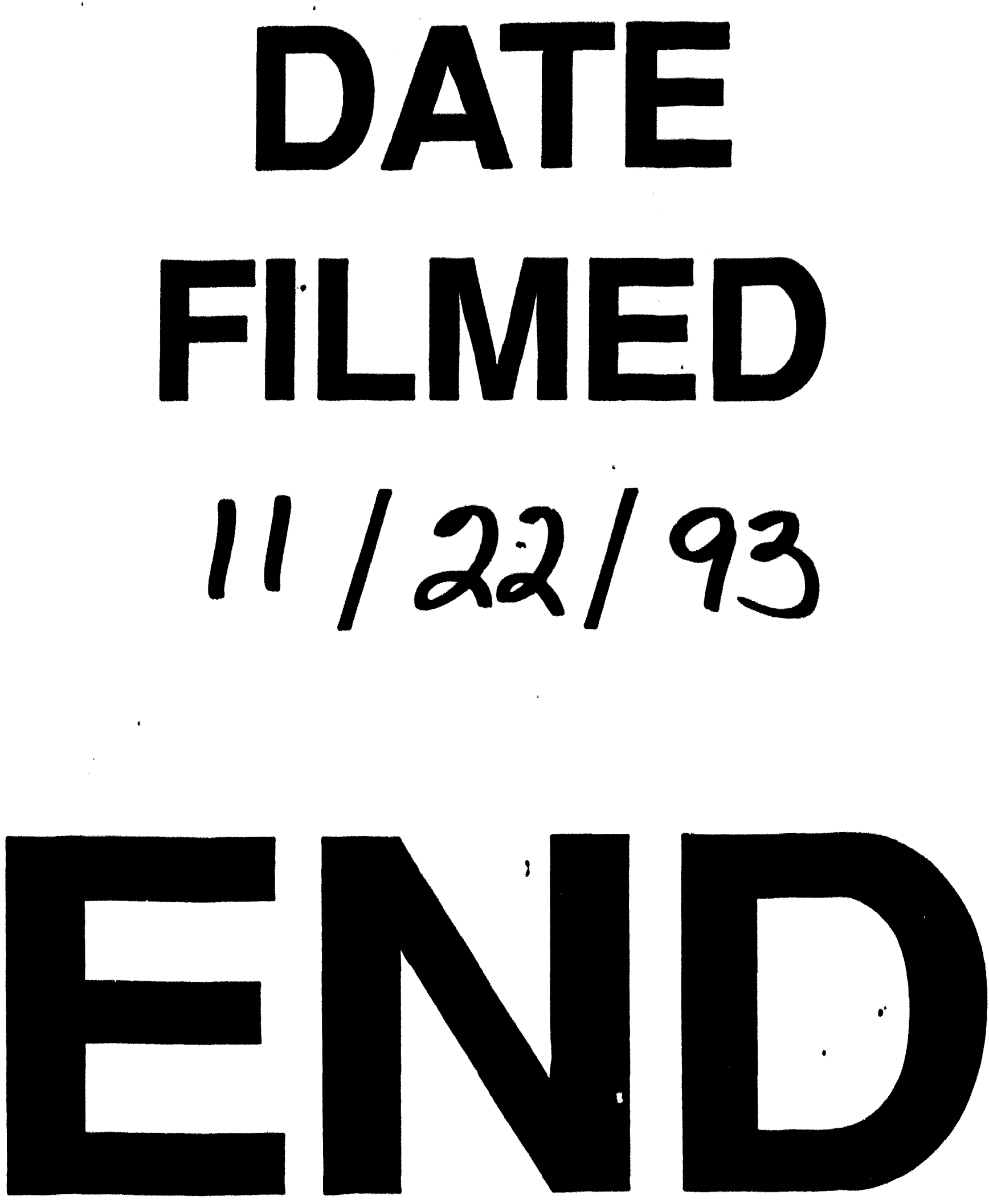
